\title{
ANALES DE LA FACULTAD DE MEDICINA
}

TOMO XXXXII N $N^{8} 4$

LIMA, CUARTO TRIMESTRE DE 1949

\section{LA ENFERMEDAD DE CARRION O VERRUGA PERUANA EN EL NNNO}

Dr. Carlos F. Krumdieck

Profesor Titular de Puericultura y Pediatría de la Facultad de Medicina de Lima Miembro de la Academía Nacional de Medicina.

DRFAMBULO

Desde muy remotas épocas, como lo atestiguan la cerámica de las antiguas civilizaciones peruanas, ha existido en diversas zonas del país, la enfermedad de verrugas.

Uno de los primeros tributos que pagaron los conquistadores fué a esta dolencia. Los cronistas que acompañaron a Pizarro la hicieron conocer al mundo occidental. Al desembarcar con sus huestes cerca de la línea ecuatorial y dirigirse hacia Coaque (en la actual provincia de Manabí, Ecuador) fueron víctimas de una mortífera y desconocida enfermedad. Los que no sucumbían a ella, sufrían de fuertes dolores, se ponían tullidos y les aparecían "berrugas" por todo el cuerpo, que al ser cortadas sangraban profusamente.

Durante el Virreinato se señaló por médicos y profanos de la Colonia la existencia de "berrugas" como enfermedad endémica en las quebradas situadas al pie de la cordillera.

En la época de la Emancipación se conoce ya mejor la enfermedad que es considerada de origen hídrico. Son las "aguas de verrugas" las que provocan esta singular dolencia, triste privilegio del Perú.

Los primeros estudios de carácter científico de la enfermedad aparecen a mediados del siglo XIX. El brote, que es el síntoma dominante, se describe con gran riqueza de detalles, es de pronóstico benigno y se contrae por contacto o ingestión de aguas inficionadas. 
En el año 1870, al efectuarse las obras de construcción del 'ferrocarril transandino a La Oroya, los médicos fueron sorprendidos por la aparición de una gravísima epidemia que diezmó al personal de ingenieros, capalaces y obreros tan luego el trazo franqueó la quebrada de Huarochirí. Desconociéndose su naturaleza, tan grave enfermedad epldémica fué designada con el nombre de "fiebre de Oroya" para diferenciarla de la malaria que también carusaba estragos entre los trabajadores.

No obstante que junto con la fiebre de Oroya se observaba numerosos casos de verruga, que ambas dolencias coexistían en las mismas zonas y que algunos de los escaşos enfermos que sobrevivían al ataque de la fiebre de Oroya presentaban erupción de verrugas, muy pocos fueron los profesionales que consideraron las dos entidades como dependientes de una causa común.

Cupo al estudiante de medicina Daniel Alcides Carrión el mérito de haber demostrado, a costa de su propia vida la identidad etiológica de ambas dolencias.

Carrión, dotado de sutil espíritu científico, de gran rectitud moral y de ascendrado patriotismo, se propuso efectuar un estudio exhaustivo de la Verruga Peruana. Para llevarlo a cabo era menester practicar delicadas investigaciones experimentales. Desechó las inoculaciones en animales por no brindar éstos, datos subjetivos concretos los que solo pueden ser proporcionados vor el hombre; para describirlos con la mayor fidelidad posible, nada más conveniente que sentirlos en la propia carne. Decidió entonces efectuar la experiencia en sí mismo.

Demostrando iquebrantable voluntad y valor temerario, sin prestar oídos ni a las reflexiones de sus amigos ni a los consejos de sus maestros, el 27 de Agosto de 1885 se inoculó con sangre de un botón verrucoso. Grande fué la sorpresa para todos los que siguieron día a día la marcha de la experiencia, incluso para el propio Carrión, al observar, no la aparición de verrugas en los puntos escarificados, sino el cuadro clínico de la fiebre de Oroya,

La experiencia de Carrión permitió establecer definitivamente la identidad etiológica de la Verruga y la fiebre de Oroya. Esta no representaría otra cosa que la fiebre anemizante oue precede en algunos casos a la erupción de aquella, tesis que había sido adelantada por distinguldos clínicos. Como justo homenaje a su 
heroico sacrificio se designaron ambas modalidades de la misma dolencia con el nombre de Enfermedad de Carrión.

El ejemplo legado por el martir de nuestra medicina estimuló el entusiasmo de los médicos peruanos por descifrar los numerosos enigmas que encerraba aquella singular enfermedad, contrayendo el compromiso de honor de estudiarla con la mayor dedicación.

Han transcurrido desde aquella trágica experiencia cerca de setenta años durante los cuales el Cuerpo Médico del Perú celebra anualmente el día 5 de Octubre una reunión solemne en homenaje a Carrión, en la que se dan a conocer los progresos alcanzados en el estudio de la enfermedad autóctona.

Fácil es imaginar cuan copiosa literatura se ha acumulado y cuantos descubrimientos se han efectuato en los 14 lustros transcurridos. Analizarlos uno a uno sería tarea muy ardua. Sin embargo, no podemos sustraemos a señalar las principales conquistas científicas alcanzadas, pudiendo afirmarse que en el momento actual se conoce la enfermedad de Carrión con tal tiqueza de detalles que no va a la zaga de las dolencias mejor conocidas, quedando, no obstante, numerosas incógnitas por despejar.

No es nuestro propósito recargar con citas bibliográficas, que forzosamente serían incompletos, este breve resumen de carácter informativo. Los esfuerzos de la Escuela Médica Peruana se encaminaron primero hacia el conocimiento detallado de la clínica de la enfermedad y su distribución geográfica, sin descuidar las investigaciones históricas de cuyo conocimiento no se puede prescindir por ser los esfuerzos del pasado y los trabajos del presente los que permiten vislumbrar en el futuro.

El más alto exponente de nuestra medicina, en los últimos años, Emesto Odriozola, publicó el cño 1898 un volumen acerca de "La maladie de Carrión" magistral trabajo que es la monografía más completa y perfecta sobre la materia que se ha producido en el Perú y cuya lectura, pese a los años transcurridos, es imprescindible a todo aquel que se interese por el tema que tratamos. A esta obra clásica tendremos que referimos constantemente en lo que a la clínica se refiere.

Al finalizar el siglo XIX y durante los primeros lustros del actual, la atención de los médicos peruanos se orientó de preferencia al estudio de la anatomía patológica y la etiología de la verruga, 
completándose y perfeccionándose su conocimiento clínico, su distribución geográfica $\mathrm{y}$ epidemiología, habiéndose pensado ya en la posibilidad de que su transmisión se opere por intermedio de un insecto hematófurgo.

Aparecieron numerosas contribuciones sobre hematología de la fiebre grorve de Carrión; se estudiaron los principales caracteres histológicos del botón verrucoso y hasta se llegó a describir un gérmen como agente etiológico de la enfermedad.

Poco tiempo después dicho microbio fué identificado como un similífico lo que dió origen a una concepción dualista, según la cual la fiebre o anemia grave de Carrión no sería otra cosa que la asociación de una afección similtífica con la Verruga durante el períoda de más intensa anemia. Esta opinión fué muy discutida.

El año 1905 Alberto Barton descubrió en los hematíes de los enfermos de fiebre grave unos corpúsculos que designó con el nombre de "cuerpos endoglobulares" a los que consideró como los verdaderos y únicos agentes etiológicos de la enfermedad.

Entre tanto, continuaron los estudios hematológicos, estableciéndose que la anemia en la fiebre grave de Carrión era de tipo pernicioso, y que en la fórmula blanca se presentaban caracteres especiales que permitían orientar al clínico acerca de las posibilidades evolutivas en los diferentes casos.

Por entonces comenzaron a interesarse en el extranjero por la endemia peruana. Investigadores alemomes e italianos aportaron importantes contribuciones confirmatorias, en su mayor parte, de los estudios realizados por la Escuela Médica Peruana.

El Departamento de Medicina Tropical de la Universidad de Harvard envió a Sudamérica, con preferente destino al Perú una comisión de sabios para estudiar la verruga.

Al celebrarse en Lima, el año 1913, el V Congreso Médico Latino-Americano, VI Pan Americano, los médicos peruanos preseniaron numerosas e importantes investigaciones sobre la enfermedad de Carrión. La Comisión Norteamericana de Harvard, en nota preliminar hizo conocer las conclusiones a que había llegado en sus trascendentales estudios. Parci ellos, la verruga eruptiva y la fiebre grave de Carrión serían dos enfermedades diferentes: la primera, producido por un virus susceptible de transmitirse por inoculación a los cinimales; la segunda, no inoculable, debida a un organismo parásito de los glóbulos rojos para el que crearon el 
género Bartonia primero y Bartonella después, en honor a su descubridor, agregándole la designación específica bacilliformis en atención a su morfología. Quedó así consagrado definitivamente el descubrimiento de Barton. Con su autoridad científica, la Escuela de Madicina Tropical de Harvard, estableció un nuevo dualismo en la concepción de la enfermedad de Carrión, que fué rebatido por la Escuela peruana.

En aquella época se dió a conocer igualmente la existencia de un mosquito especial, la Titira (Phlebotomus Verrucarurn), propio de. las zonas verrucosas, al que se consideró, con sólidas pruebas, como el agente vector de la enfermedad de Carrión.

En los años sucesivos, los estudios tienen por rinalidad demostrar la unidad etiológica de la endemia peruana. Para lograrlo se efectúa gran número de investigaciones experimentales, precisándose los caracteres histopalológicos del verrucoma, en el que se descubre la existencia de la Bartonella, quedando definitivamente comprobada la tesis peruana sobre la unidad etiológica de la Verruga y la fiebre de Oroya que la trágica experiencia de Carrión había llevado al convenciniento de todos los médicos del Perú. Se pudo en fin, obtener la Bartonella en cultivo puro de la sangre de enfermos con flebre grave de Carrión, cuya inoculación reprodujo el botón verrucoso en los animales.

Conocidas las manifestaciones clínicas, los factores epidemiológicos, la ontomía patológica y la etiologia de la enfermedad, debía encararse el problema patogénica y la interpretación fisiopatológica de los principales desórdenes funcionales determinados por la bartonella en el organismo hur.ano.

Basándose en todos estos datos se delineó la primera concepción patogénica de conjunto de la erifermedad, según la cual se trata de una afección del sistema retículo endotelial que presenta dos fases: una primaria, hemática, caracterizada anatómica y bacteriológicamente por el parasitismo intenso de los hematíes por la bartonella, y que clínicamente se revela por una fiebre anemizante grave: la fiebre grave de Carrión o fiebre de Oroya de los antiguos clínicos; y una segunda fase, histioide, con parasitismo endotelial y reacción hiperérgica especial que conduce a la formación de verrugas.

Profundizando más aún los estudios, se descubre que es todo el sistema mesenquimal el interesado, el cual puede polarizar sus 
funciones según las necesidades: ora estimulando los elementos histioicitarios que captan y aniquilom las bartonelas para que el organismo se libere del gérmen invasor; ora determinando la proliferación angioblástica característica del verrucoma.

La morfología y caracteres tintoriales de la Bartonella son objeto de atentas investigaciones, llegándose a demostrar que en el glóbulo rojo no se trata de un cuerpo endoglobular sino simplemente epiglobular, y que su aspecto morfológico es Ricketziforme, con tendencias parasitarias endoteliotrópicas. Si a estos dos últimos caracteres se agrega la transmisión de la enfermedad por picaduras de insectos, y ciertos aspectos clínicos, se hace posible establecer relaciones añalógicas entre las Ricketziosis y la Bartonelosis humana.

La existencia de formas crónicas y recidivantes de la verruga, por una parte, $y$, por otra, la relativa facilidad de descubrir la bartonella por hemocultivo, indujo a practicar esta investigación en forma seriada en individuos aparentemente sonos pero procedentes de zonas verrucosas, lo que permitió demostrar la existencia de portadores asintomáticos que serían los verdaderos reservorios humanos del virus.

El extraordinario polimorfismo que afecta la bartonella: bacilar en los medios de cultivo y en la sangre periférica, Ricketziforme en los endotelios, y clamidozoica en los verrucomas, sugiere una nueva teoría patogénica basada en posibles mutaciones del agente productor, cuya acción patógena estaría condicionada por la modalidad morfológica que afecte: en tanto que bacteria en la sangre y los cultivos, porvocaría la fiebre anemizante grave de Carrión; en tanto que ricketzia parasitando los endotelios, produciría la fiebre grave de Carrión; y en tanto que virus, engendraría los verrucomas característicos. Todas estas mutaciones serían reversibles y los cultivos en medios artificiales darian siempre origen a la Bartonella baciliformis.

El estudio de las bartonelosis animales abre fecundas vías aplicables al mejor conocimiento de la fisiopatología del mal de Carrión. Solamente una especie, la Bartonella baciliformis es patógena para el hombre, mientras que existen numerosas y muy difundidas especies del género Hemobartonelas que parasitan a los animales en los que se observan variados cuadros clínicos, muchos de ellos semejantes a la bartonellosis humana. 
La distribución geográfica se amplía al descubrirse en el departamento de Nariño, en Colombla, la existencia de la enfermedad de Carrión bajo una forma epidémica solo comparable a la que ofreció la fiebre de Oroya en el Perú el año 1870, que produjo entre los médicos colombianos las mismas perplejidades que produjera entre nosotros mientras se construía el ferrocarril transandino. En el Ecuador, igualmente se han presentado casos típicos. La bartonelosis humana, en consecuencia ha dejado de ser una endemia limitada a zonas circunscritas del Perú, para extenderse en un amplio sector del lado occidental de la América del Sur.

La introducción de los antibióticos en el arsenal terapéutico ha puesto en manos de los clínicos un arma poderosi para el tratamiento de la enfermedad. Todos los agentes terapéuticos empleados con anteriorldad, incluso los más potentes quimioterápicos, no dieron resultados satisfactorios.

Los modernos inserticidas de otro lado, han probado su eficacia frente al Phlebotomus, permitiendo esperar que una campaña sanitaria coriveniente conducirá algún día a la erradicación del mal.

Hemos tratado de exponer esquemáticamente los progresos llevados a cabo en el conocimiento de la enfermedad de Carrión. Para facilitar su lectura hemos omitido deliberadamente consignar, dentro de lo posible, techas y nombres propins. Recomendamos a quienes se interesen por los aspectos históricos consultar las obras de Zárate ${ }^{1}$, Odriozola ${ }^{2}$, Patrón $^{3}$, Monge $^{4}$, Rebagliatr ${ }^{5}$, Fatacioli $^{6}$, VARGas FANO', y sobre todas ellas las de Valdizán ${ }^{8}$.

Consideramos de nuestro deber destacar un hecho: casi todas las observaciones en las que se sustenta la actual concepción de la Verruga, se han recogido en individuos adultos. Muy contadas son las publicaciones que atañen a la infancia no obstante ser los niños de las zonas endémicas los más frecuentemente atacados desde su más tierna edad.

La experiencia adquirida durante un cuarto de siglo de actividad pediátrica me ha permitido acumular numerosa casuística que. al darla a conocer, llenará en parte el vacio que significa el desconocimiento de la enfermedad de Carrión en las diversas etapas de. la infancia. 
En ninguna publicación pediátrica de las numerosas enciclopedias, tratados, manuales y revistas consultadas, hemos visto mencionada la enfermedad de Carrión. Solamente ${ }^{T}$ ULES CombY ${ }^{9}$ en su libro de Enfermedades de la infancia consigna la Verruga peruana, con datos muy anticuados.

Por estar dotados los niños de un vigoroso y activo sistema retículo endotelial, desarrollan la verruga con un curso casi siempre benigno. Pocas veces se observa en ellos el despetrar de microbismos latentes que cobran virulencia inusitada al amparo de la bartonelosis. En ellos, pues, la enfermedad de Carrión se manifiesta con gran pureza, sin tomar en préstamo síntomas ajenos, lo que permiłe describirla clínicamente en sus más genuinas manifestaciones.

Y como hasta el presente no se ha efectuado un estudio de conjunto sobre la Verruga en la Infancia, considero un deber dar a conocer este ensayo, en la confianza de despertar el interés de los pediatras por las investigaciones en el campo de la bartonelosis que sirvan para enmendar los errores y subsanar lís omisiones en las que seguramente he de incurrir.

\section{DISTRIBUCION GEOGRAFICA Y EPIDEMIOLOGIA}

Durante muchos años se sostuvo que la enfermedad de Carrión estaba circunscrita estrictamente a determinadas quebradas del Perú y que duronte el Incanato y las épocas preincaicas abarcaba otras zonias de la costa, como podía inducirse de la epidemia que contrajeron en Coaque los conquistadores del Imperio incaico.

Esta tesis fué sostenida por OdRrozol ${ }^{2}$ en su notable monografía aparecida el año 1898. En ella se consideraba a la verruga como una dolencia propia del Perú, limitada a estrechas regiones comprendidas en los Departamentos de Ancash, Libertad y Lima.

Posteriormente fueron describiéndose otros muchos lugares en los que la enfermedad autóctona existía en forma endémica. Muy nutridos han sido los aportes relativos a la geografía y epidemlología. Entre ellos se destacan por su trascendencia los trabajos de Antúnez ${ }^{10}$, Valdez ${ }^{11}$, Gómez ${ }^{12}$, Pérez Velásquez ${ }^{13}, F_{\text {atacioli }}{ }^{6}$, Lorente y Florez Córdova ${ }^{14}$, Weis ${ }^{15}$, Rebagliati ${ }^{16}, 17,18$ Giles $^{19}$, etc. quienes pusieron en evidencia zonas verrucosas diseminadas en 
enormes extensiones territoriales del país, comprendidas no sólo en las proximidades de la costa y de la sierra sino también en la selva.

En el año 1939, Pariño Camargo20, verificó la existencia de un foco endémico en Nariño, al sur de Colombia, y Hertig ${ }^{21}$ en Ecuador. La verruga, pues, es extiende endémicamente en una amplia extensión del occidente de la América del Sur que abarca desde $2^{\circ}$ de latitud Norte, hasta $13^{\circ}$ de latitud Sur.

Limitando nuestro trabajo a la repartición geográfica de la verruga en el Perú, opinamos, de acuerdo con ReBagliati ${ }^{17}$ que ha efectuado los estudios más completos sobre esta materia, que existen dos grandes regiones donde reina la enfermedad de Carrión: una occidental que comprende un gran número de quebradas tributarias de los ríos que desembocan en el Océano Pacífico; y otra oriental, cuyas zonas verrucosas confluyen hacia las hoyas de los ríos Marañón. Huallaga y Mantaro, ríos todos ellos que, juntando sus aguas en la selva del Perú, dan origen al Amazonas. De estas dos grandes regiones, la mejor estudiada y conocida es la occidental u hoya de las vertientes del Pacífico.

Los lugares en donde existe la verruga, cualquiera que sea su latitud o su altura sobre el nivel del mar, bien se trate de ambientes urbanos o rurales, ofrecen en general las mismas características orohidrográficas. Siempre son quebradas profundas, cercadas por altos y escarpados cerros, bañadas por ríos de poco caudal y bastante pendiente, de temperatura muy cálida durante el día, debida a la fuerte radiación solar y a muy escasas corrientes de aire que las refresquen, pero que en la noche se toman frías por las brisas de la cordillera. Gorbitz ${ }^{22}$, insiste mucho en el fenómeno de saturación del aire por la fuerte humedad reinante como característica de las zonas verrucosas. La vegetación es escasa. No muy pródiga la fauna de vertebrados, no así la de insectos, que es abundante, entre los cuales la "titira" (Phlebotumus Verrucarum) es constante.

Son tan numerosos y dispersos los focos en los que se ha señalado la existencia de la verruga en el país, que Weiss ${ }^{15}$ considera más conveniente y fácil precisar los lugares que, reuniendo las características que acabamos de apuntar, no sean zonas verrucosas, más bien que señalar una enorme relación de nombres de ciudades, pueblos, aldeas y rancherías en las que se ha ob- 


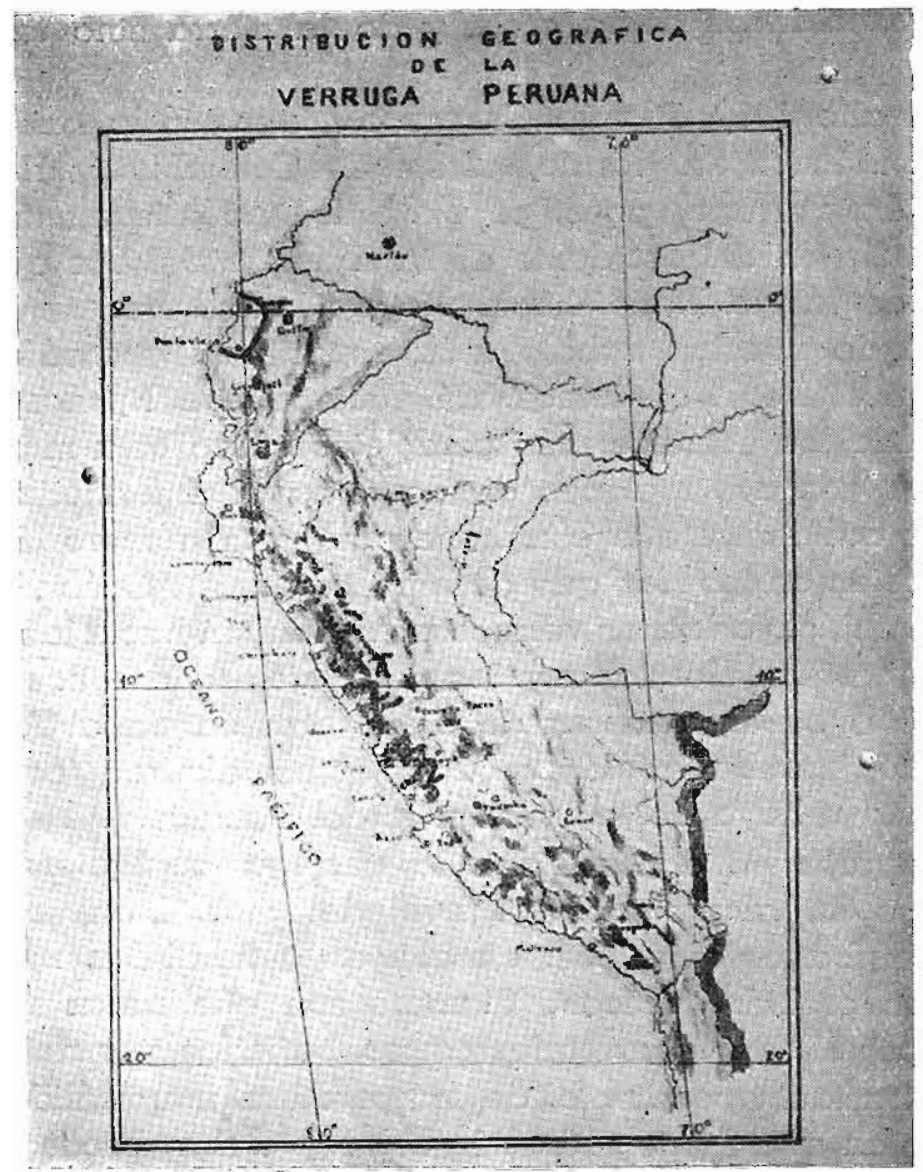

servado casos de enfermedad de Carrión, en muchos de los cuales "no se ha determinado con exactitud si los enfermos han adquirido la dolencia en el lugar mismo o han acudido a él después de haberse infectado en otra zona".

En las quebradas verrucógenas la enfermedad se presenta endémicamente todo el año, acentuándose como brotes epịdémicos en determinadas épocas. GómEz ${ }^{12}$ dió a conocer el importante hecho de que, según el régimen pluvial, los lugares en que existe la endemia aumentan su amplitud durante las fuertes lluvias, estrechóndose en la época de sequía. Esta observación inspiró la feliz expresión de Weiss ${ }^{15}$ de "halo epidémico". 
Los caracteres de la infección verrucosa misma varion un tanto según los lugares, predominando en unos las formas agudas, malignas, de alta gravedad; en otros, las formas leves, benignas, rápidamente eruptivas; $y$ en otros en fin se observa con mayor frecuencia las formas crónicas y recidivantes, siendo este tipo y el primero más frecuentes en el adulto, en tanto que el segundo se comprueba preferentemente en el niño.

Toda aquel que viaje por comarcas vermcosas, observa con bastante regularidad a niños víctimas del mal autóctono que discurren por las poblaciones mostrando su erupción sin manifestar mayor incomodidad. Al interrogar a los lugareños ¿por qué los adultos no son víctimas de la enfermedad?, casi tod'ús responden en la misma forma: "por que han pasado la verruga en la niñez". Algunos dejan constancia de que los adultos solo la adquieren cuando no han sido víctimas de ella en la infoncia. Estos datos los obtuvimos en una encuesta que practicamos el año 1930 en el pueblo de Surco.

Gómez ${ }^{10}$ fué el primero que hizo esta observación en su notable estudio sobre la verruga en la provincia de Yauyos, agregando que "los niños hacen siempre formas benignas quedando inmunizados para todo el resto de la vida". Weiss ${ }^{15}$ vá más allá aún, al afirmar que en las zonas endémicas los nativos se infectan en la primera infancia, mientras que quienes la adquieren en la región del "halo epidémico" lo hacen por lo general en las edades preescolar y escolar.

El estudio epidemiológico más importante ha sido efectuado por Hurtado, Merino y Pons ${ }^{23}$ en la pequeña aldea de Tomamesa, situada en la quebrada del Rímac a 62 kilómetros de Lima y a una altura de 1,513 metros sobre el nivel del mar. La investigación la llevaron a cabo en los 128 habitantes del lugar, de los cuales 60 eran nativos y 68 forasteros. De los primeros, 36 confesaron haber tenido la enfermedad y 6 presentaban la erupción típica. De los 35 que habían pasado la verruga 21 , o sea el $60 \%$, la contrajo en el primera año de vida; 13,0 sea el $37 \%$, en el segundo año, y solamente 1, o sea el $3 \%$ a los 21 años de edad.

De los 68 forámeos, 46 proporcionaron antecedentes de haber tenido verruga, o sea algo más del 67\%. De ellos, 42 la adquirieron en el lugar y sólo 4 en zonas alejadas. 


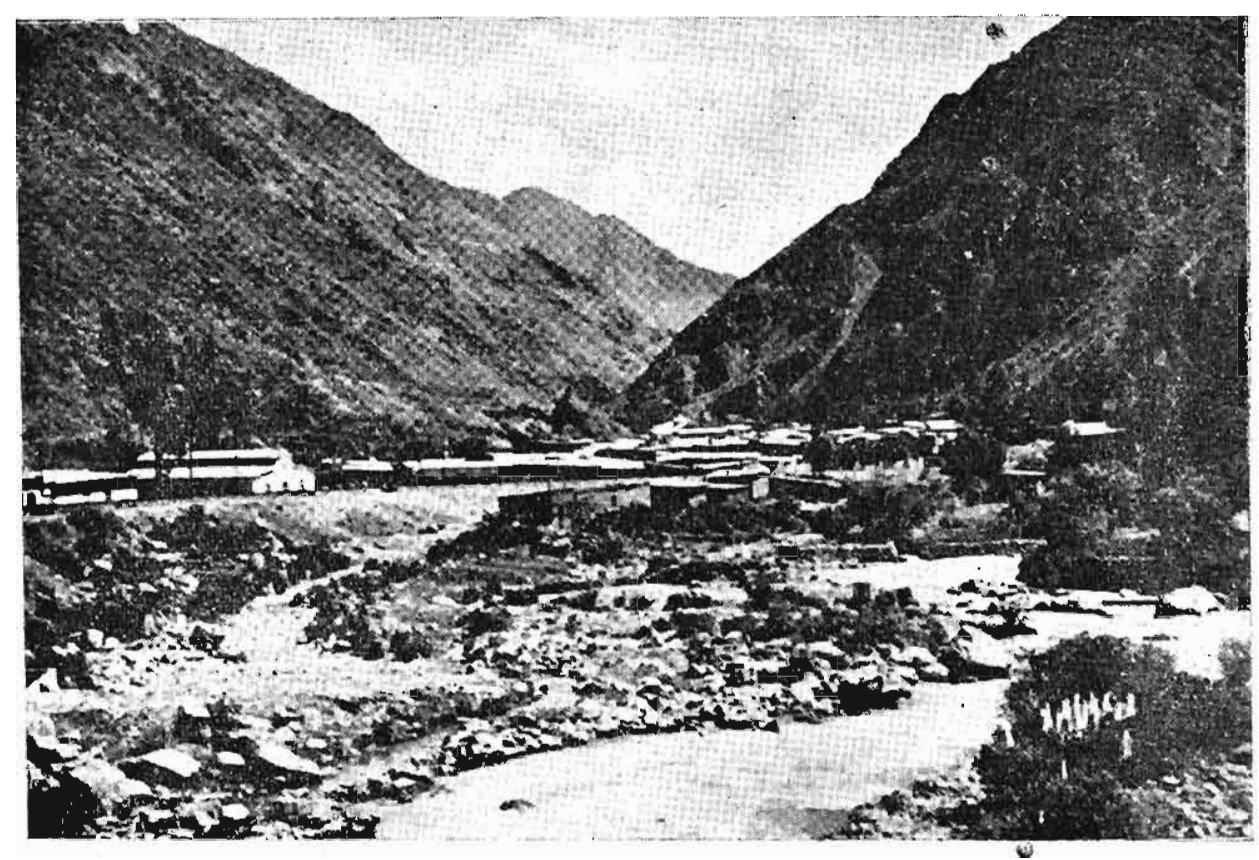

Zona verrucosa de la quebrada del Rimac.

PHLEBOTOMUS VERRUCARUM

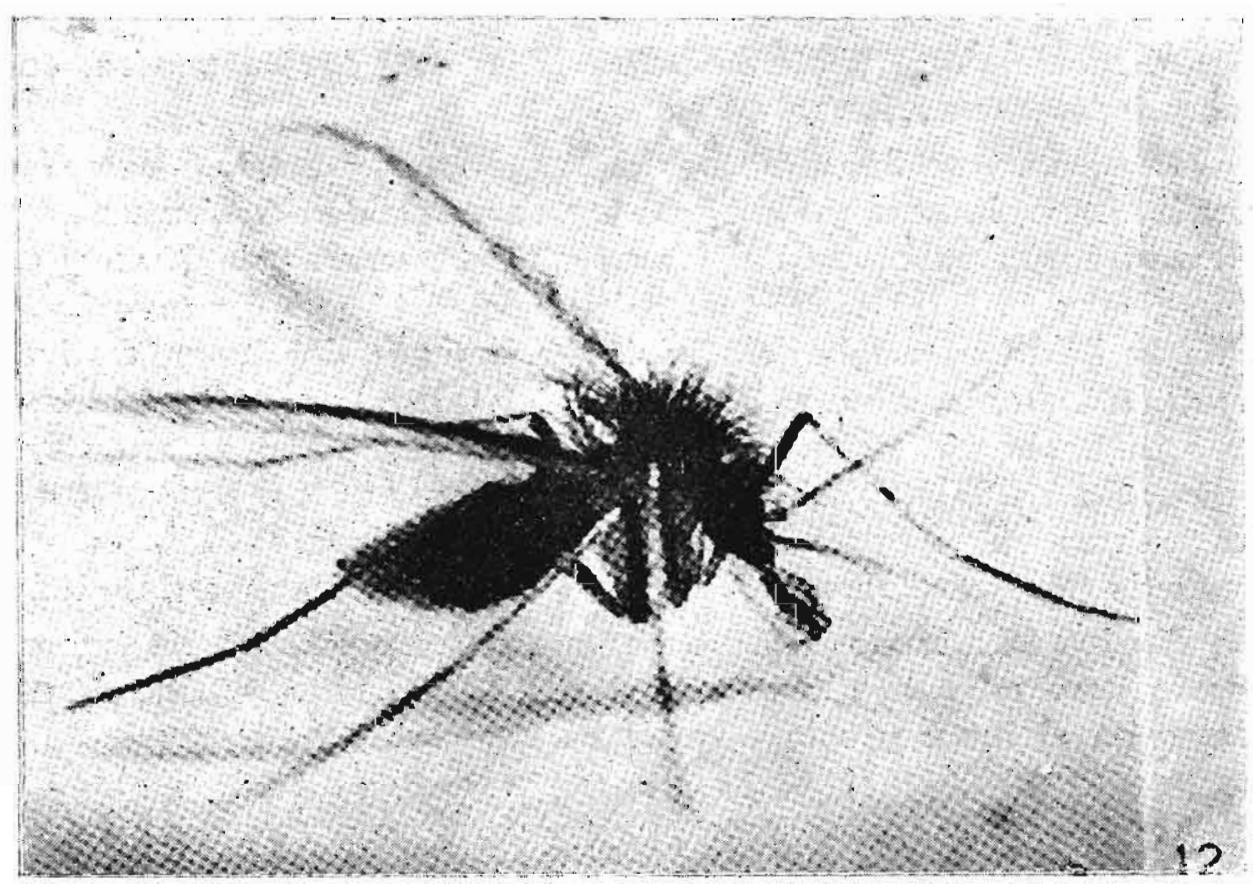

Agente transmisor de la enfermedad de Carrión. 
Practicaron estos investigadores, además de importantes estudios hematológicos, 53 hemocultivos en medios apropiados, habiendo comprobado la existencia de Bartonella Bacilliformis en 8 de ellos. De estos 8 hemocultivos positivos, sólo uno provenía de un sujeto que presentaba brote verrucoso. Los 7 restantes se obtuvieron de individuos aparentemente sanos; de ellos 3 en niños menores de 10 años.

Las observaciones que apuntamos demuestran en forma incontrovertible: 19 que la verruga en las zonas endémicas es una enfermedad de la infancia, y, $2^{\circ}$ la existencia de portadores de gérmenes, aparentemente sanos.

Mackehenie ${ }^{24},{ }^{25}$ basado en ciertas experiencias llevadas a cabo con plomtas oriundas de las zonas verrucosas, del género Jatropha ( $\mathrm{sp}$. Baciacantha y Macratha) en cuyo latex existen corpúsculos bartoneliformes, lanzó la opinión de que dichas plantas pudieran ser el principal reservorio del virus verrucoso. Esta opinión ha sido tomada con escepticismo por la mayor parte de los verrucólogos̀.

La enfermedad no es contagiosa aunque si inoculable, como quedó demostrado por la experiencia, de Carrión con material humano procedente de botón verrucoso, de Kuckzynski con cultivos puros de Bartonella, y de García Rosell quien accidentalmente, al practicar una transfusión samguínea, se inoculó sangre, de un enfermo de fiebre grave de Carrión, desarrollando tras un período febril la erupción verricosa característica.

La transmisión requiere el concurso de un vector intermediarío. ARCE ${ }^{26}$ fué el priməro en sostener esta tesis negando rotundamente el origen hídrico que había sido admitido hasta fines del siglo pasado. Prolijas investigaciones anamnésicas y la opinión de que el microbio productor de la enfermedad de Carrión tuviera analogías con los hematozoarios lo llevaron a afirmar que el vehículo transmisor debía ser un insecto alado, hematófago y que picara de noche. Basado en estas inducciones y en la presencia constante de la "titira" ( $\mathrm{Ph}$. Verrucarum) en todas las zonas verrucosas, el entomólogo norteamericano TowsEND ${ }^{27}$, le asignó papel transmisor de la verruga. Trabajos posteriores de Battisti$\mathrm{NI}^{28}$, NoGUCHI y colaboradores ${ }^{29}$ y sobre todo HeRTIG ${ }^{21}$ demostraron ampliamente la aseveración de Towsend. 


\section{ETIOLOGLA}

Hasta el año 1885, la Verruga peruana era considerada como una afección cutónea, dóndose como hecho demostrado que en algunas regiones existían quebradas cuyas aguas provocaban la enfermedad. Tan grande era el temor a las "aguas de verrugas" que refiere Valdizán ${ }^{30}$ que en las memorias de O'Connor, publicista $Y$ soldado que luchó denodadamente por nuestra independencia, se puede leer que los ejércitos libertadores fueron instruidos sobre el grave peligro que significabon tales aguas, prohibiéndose al ejército, no sólo beberlas, ni siquiera dejarse salpicar por ellas al pasar los arroyos. Tschudr ${ }^{31}$ decía que bastaba beber un solo vaso de esas aguas para adquirir la enfermedad.

Las primeras impresiones acerca de la posibilidad de manifestaciones extracutáneas de la verruga fueron entrevistas por EspiNAL ${ }^{32}$ al observar que los enfermos de fiebre de Oroya, en los pocos casos que sobrevivían, presentaban brote de verrugas. Afirmaba este clínico que la fiebre de Oroya era el síntoma precursor de la erupción, opinión compartida por distinguidos clínicos de la época.

El trágico resultado de la memorable experiencia de Carrión poniendo de relieve la unidad etiológica de ambas dolencias y su inoculabilidad, demostró la certera intuición clínica de Espinal, haciendo pensar en la posible existencia de algún agente microbiano productor de ia enfermedad.

Las pesquisas de los investigadores se encaminaron a la búsqueda del microbio. IzQuIERdo ${ }^{3 y}$ señaló la presencia de un bacilo ácidoresistente; FlóREs ${ }^{34}$ aisló unos "cocus" agrupados en cadeneta en cultivos de sangre de verrucosos. Ninguno de estos gérmenes respondió a los postulados de Koch.

En 1900, BARToN ${ }^{35}$, por cultivo de pulpa esplénica de cadáveres de sujetos recién fallecidos de enfermedad de Carrión, aisló un bacilo que consideró como el agente específlco de ella. Cuatro años más tarde, Biffi, TAMAYo y Gastiaburú ${ }^{36}$ comprobaron que el "bacilo de Barton" no era el gérmen patógeno de la verruga sino un microbio del grupo similtífico que, al complicarla, le comunicaba una fisonomía especial que no era otra cosa que la fiebre de Oroya o fiebre grave de Carrión, planteando en esta forma una concepción dualista. 
BARTON ${ }^{37}$, que se había propuesto encontrar el agente cousal de la enfermedad, trabajando tenaz y perseverantemente, descubrió en los hematíes de enfermos de fiebre grave de Carrión unos "cuerpos endoglobulares" en forma de bastoncitos cortos y delgados, que para él representaban el verdadero microbio patógeno. En estudios posteriores, el mismo BARTON ${ }^{38}$ precisó la morfología de dichos cuerpos endoglobulares, señalando los combios morfológicos que experimentan durante la evolución de la enfermedad y su relación con la anemia, afirmándose en los conceptos emitidos acerca del rol que desempañaban como los microbios específicos de la verruga peruana.

Mientras que todos los médicos peruanos concedieron a los "cuerpos endoglobulares de Barton" gran importancia diagnóstica, muy pocos los admitieron como los agentes productores de la enfermedad de Carrión. Un gran número los consideraron como restos nucleares.

La primera expedición de la Escuela de Medicina Tropical de Harvard, al visitir el Perú, abordó el estudio de la Verruga. Strong y sus colaboradores: Tyzzer, Brues, Sellards y Gastiaburú, después de dar $a$ conocer en una nota preliminar ${ }^{39}$ presentada al $\mathrm{V}$ Congreso Médico Latino-Americano (VI Pan Americano) las conclusiones de sus estudios, publicaron el año 1915, bajo el título "Report of first expedition to South America"40, un volumen profusamente ilustrado sobre los resultados alcanzados en las investigaciones que habian llevado a cabo. Dicho trabajo de carácter fundamentalmente experimental, es uno de los mayores aportes al conocimiento de la endemia peruana. Se consagra en él a los "cuerpos endoglobulares de Barton" carácter de seres vivos reputándolos como los verdaderos y específicos agentes determinantes de la fiebre de Oroya y los designan con el nombre de Bartonella bacilliformis (Strong 1913) en homenaje a su descubridor: Barton. En cuanto a la verruga misma, sostienen que es una enfermedad diferente, inoculable a los animales y producida por un virus. Strong y su escuela establecen el dualismo de la enfermedad de Carrión, bajo un aspecto diferente al de la concepción de Biffi y colaboradores ${ }^{36}$.

Desde su enunciación, esta nueva concepción fué rebatida por la Escuela Médica Peruana con poderosos argumentos clínicos, epidemiológicos y experimentales. La gran autoridad científica 

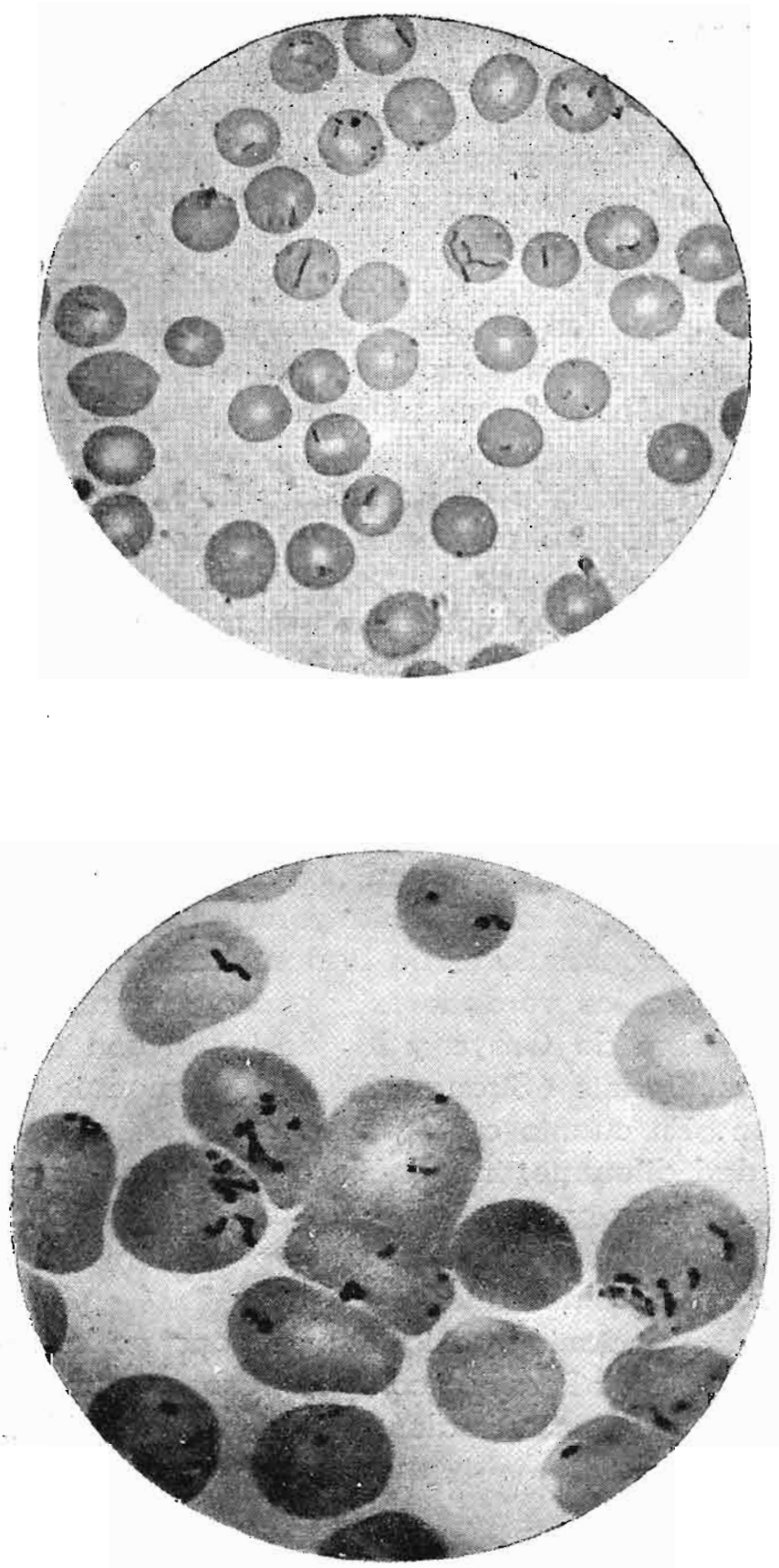
de Srtong y su Escuela y la difusión de su importante obra trajeron como consecuencia que en casi todo el mundo es admitiera que la verruga y la fiebre grave de Carrión erom dos entidades mórbidas diferentes.

Un hecho quedó definitivamente admitido: la Bartonella baciliformis como agente específico de la enfermedad de Carrión. Demostrar su presencia constante en el nódulo verrucoso, obtenerla en cultivo puro en las dos enfermedades y poder reproducirlas por inoculación experimental, demostraría el criterio unicista. Fueron estos los problemas que se propusieron resolver los médicos peruanos para comprobar la doctrina unicista.

La Bartonella bacilliformis se presenta en las láminas de sangre coloreadas por cualquiera de los derivados del Romanowski como bastoncillos alargados que se tiñen de una coloración rojiza - violeta, de una longitud aproximada de $2 \frac{1}{2}$ micras. Se les observa unas veces aisladas, otras, agrupadas, pudiéndose contar desde $1 \circ 2$ hasta $15 \circ 20$ elementos en un eritrocito. En los casos muy intensos, todos los hematíes pueden estar parasitados. StRONG ${ }^{40}$ señala como carácter tintorial una acentuación cromática en las extremidades. Los bacilos pueden ser rectos, incurvados - afectar la forma en "Y". En las preparaciones en f́resco se puede advertir movimientos lentos de progresión del gérmen dentro del glóbulo.

La forma bacilar precedentemente descrita es la admitida por Barton ${ }^{37}, 38$, Gastiaburú y Rebagliatr ${ }^{41}$. Strong y colaboradores $^{40}$, WeINMAN ${ }^{42}$ y muchos otros. Este aspecto morfológico experimenta modificaciones en los diversos momentos evolutivos de la fiebre anemizante grave de Carrión. Cuando tiende a declinar, las bartonellas afectam una forma ligeramente redondeada.

Con técnicas de coloración especiales, MackeHenie y Barristi$\mathrm{NI}^{43}$ pudieron poner en evidencia la presencia de bartonellas en los verrucomas, lo que comprobaron después MACKEHENIE y WeISS ${ }^{44}$ confirmando los resultados que había señalado ReBaglia Tí ${ }^{5}$ el año 1913.

Hercelles ${ }^{45}$ aseguró que la forma bacilar de la Bartonella solo se observa en la sangre periférica. En los tejidos y en los nódulos verrucosos afecta el tipo redondeado, interpretado por otros investigadores como forma degenerativa del gérmen y por él como 
su forma habitual, habiendo propuesto que se designe, con más propiedad, con el nombre de Bartonella cocoide.

MACKEHENIE ${ }^{48}$, empleando métodos de coloración muy diferenciada, encuentra que la Bartonella tiene la forma de una palanqueta con dos masas fácilmente coloreables en las extremidades, unidas entre si por un tenue filamento que le comunica un aspecto Ricketziforme. AlDANA ${ }^{47}$ considera que se trata de bacilos de coloración bipolar.

WEINMAN afirma que la Bartonella es extraordinariamente polimorfa, afectando en la sangre el aspecto preferentemente bacilar descrito por BARTON ${ }^{38}$, y en los nódulos verrucosos y endotelios vasculares el aspecto ricketziforme.

Se sostuvo hasta el año 1929 que la Bartonella era endoglobular. En aquella fecha los estudios de ALDANA 47 , demostraron que el gérmen no estaba situado dentro del hematíe, sino fuera de él adhiriéndose a su superficie, siendo en consecuencia un microbio epiglobular que en forma accidental y transitoria parasita al glóbulo rojo. Hurtado, Pons y Merino ${ }^{48}$, Wëinman ${ }^{42}$ y otros muchos han confirmado estas observaciones.

El notable trabajo de la escuela de medicina tropical de Harvard había puesto de manifiesto que la Bartonella parasitaba específicamente las células de los endotelios capilares donde encontraba apropiado albergue para reproducirse en gran contidad. Por este carácter Alzamorata la considera como un gérmen endoteliotropo y no como un hemoparásito.

Durante cerca de 20 años fueron infructuosos todos los esfuerzos encaminados a obtener la Bartonella en cultivos. BAtTistinis el año 1920 obtuvo sus primeros éxitos en este sentido, los que dió a conocer 5 años más tarde, época en la que Hercelles ${ }^{51}$ y su escuela alcanzaron análogos resultados con técnicas diferentes: mientras Battistini cultivaba la Bartonella en medios semisólidos, Hercelles los obienía en medios líquidos.

En los cultivos frescos las Bartonellas afectan la forma bacilar, $y$ en los medios envejecidos, la cocoide, lo que se atribuye a procesos degenerativos del microbio.

Los estudios bacteriológicos practicados por BATtistin ${ }^{52}$ y por AldanA ${ }^{47}$ para solo citar a los que más se han ocupado del asunto, demuestron que se trata de un gérmen aerobio estricto, cuya temperatura óptima de desarrollo es de $28^{\circ}$, requiriendo la oscuri- 
dad. El medio debe ser de reccción neutra o ligeramente alcalina ( $\mathrm{Ph} .6,8 \propto 8,2$ ). Se necesita, para cultivar con éxito la Bartonella, de medios enriquecidos con albúnimas, preferentemente sangre humana.

El microbio tiene una gran resistencia en los medios de cultivo, siendo en cambio muy sensible a la acción de los antisépticos y del calor. Carece de acción hemolítica, no liquefacta la gelatina, ni posee acción fermentativa sobre los azúcares. No es filtrable, pues no atravieza las bujías Berckefeld $\mathrm{V} \circ \mathrm{N}$.

Sus caracteres morfológicos y tintoriales son semejantes, sin ser idénticos, a los que presenta en la sangre periférica, afectando dos formas principales: Bacilar y cocoide. En los medios envejecidos, los elementos cocoides se reunen en zoogleas. No toma el Gram.

Desde las experiencias de Jodassohn y SeIfFert ${ }^{53}$, de Mayer Rocha Lima y Werner ${ }^{54}$, de Ribeyro, Arce y Mackehenie ${ }^{55}$ y Strong y colaboradores ${ }^{40}$ se sabía que la verruga era susceptible de reproducirse en la forma eruptiva por inoculación a diversos animales, partiendo del botón verrucoso, pero no se había logrado transmitirles la fiebre de Oroya.

Una feliz inoculación praciticada por BAtristini ${ }^{50}$ determinó en el mono (Macacus Rhesus) un cuadro anémico semejante al de la fiebre grave de Carrión, con presencia de Bartonellas en la sangre. El animal falleció 24 días después de la inoculación, comprobándose a la autopsia lesiones tuberculosas concomitantes.

Numerosas experiencias llevadas a cabo ulteriormente por Noguchr y colaboradores 53 , 57, 58, 59, partiendo de cultivos de Bartonellas, confirmaron los estudios experimentales anteriormente efectuados. Estos mismos investigadores lograron producir la bartonelosis en animales, por picadura de Phlebotomus Verrucarum infectados con cultivos de Bartonellas.

Como fruto anticipado de la segunda expedición al Perú de la Escuela de Medicina Tropical de Harvard, realizada el oño 1937, que presidió también Richard Strong y la integraron H. Pinkerton, D. Weinmon, M. Hertig y B. Bennet, dieron a conocer en una nota preliminar el resultado de sus investigaciones. De ese documento ${ }^{85}$ copiamos textualmente el siguiente párrafo: "El cultivo de la Bartonella de ambas formas de la enfermedad, aparentemente tienen una procedencia idéntica y ciertas observaciones preliminares 
de Ia histología y citología de las lesiones confirmon la idea que la Verruga peruana y la fiebre grave de Carrión son producidas por un mismo microorganismo". Con ésto, la doctrina, unicista de la Escuela Médica Peruana, tan tenazmente sostenida, desde el sacrificio de Daniel $A$. Carrión, quedó definitivamente consagrada en la ciencia.

Entre los factores etiológicos coadyuvantes, deben considerarse, la exposición a la picadura del Phlebotomus y la disposición especial del organismo para anidar la Bartonella.

La existencia de individuos infectados, sin manifestar enfermedad ni haber padecido jamás de ella, pone de manifiesto que se requieren condiciones especiales, aún desconocidas, para contraerla.

Los conocimientos clínicos y epidemiológicos que se poseen demuestran una tolerancia mejor de la raza india y una mayor labilidad de la blanca. Igualmente, la infección es menos severa en el sexo femenino que en el masculino, estando probada la receptividad del niño para adquirir la enfermedad, quĕ evoluciona en él en forma generalmente benigna.

\section{CARACTERES DE LA VERTUGA EN LOS NIÑOS}

Antes de abordar el estudio semiológico, nosográfico, clínico y teropéutico de la Enfermedad de Carrión en el niño, considero necesario señalar las experiencias en las que reposan nuestras descripciones.

Las fuentes de investigación en las que se basan las opiniones que sustento se refieren a un número bastante elevado de observaciones clínicas acumuladas en más de 25 años de intensa actividad en hospitales y en práctica privada, además de la autoobservación, por haber sido víctima de la endemia nacional que adquirí en el callejón de Huaylas.

Durante los 8 meses que duró la evolución de la verruga en mi caso, contraje ante mi mismo el compromiso de dedicar una parte de mis esfuerzos a su estudio, sobre todo porque, entonces, se estimaba a la Enfermedad de Carrión, como una dolencia estrictamente peruana.

Por dedicarme a la Pediatría, fué en este campo en el que encaminé mis investigaciones, recogiendo con la mayor atención 
y prolijidad posibles todas las observaciones de verruga peruana, estudiando preferente, sus modalidades clínicas y evolutivas en la infancia creyendo un deber darlas a conocer.

Durante el año 1930, llevé a cabo una serie de excursiones en la zona verrucosa del pueblo de Surco, a 2,030 metros sobre el nivel del mal y a 70 kilómetros de la ciudad de Lima, habiendo efectuado una serie de estudios y encuestas epidemiológicas que no fueron dadas a publicidad.

Lo que más llamó nuestra alención fué la gran cantidad de niños menores de 7 años que deambulaban por las estrechas callejuelas de la aldea exhibiendo sus brotes verrucosos, sin que aparentemente les produjera ningún trastorno.

Como datos estadísticos rigurosamente verificados, solo nos es posible presentar los compilados en el Hospital del Niño durante Ios años 1940-1948. Ellos comprenden 50 enfermos cuyas historias están archivadas en ese Nosocomio. En esos nueve años se prestó asistencia hospitalaria a 38,418 enfermos, excluyendo los de consultorius externos, cuyas cifras son mayores aún.

La incidencia de la enfermedad de Carrión entre los niños hospitalizados solo alcanza al 1,3 por mil ingresos, cifra muy baja debida:

18 A que la ciudad de Lima no es zona verrucosa;

$2^{9}$ A la benignidad con que casi siempre evoluciona la bartonelosis en la infancia; $y$

$3^{\circ}$ A que solamente se hospitalizan los casos graves: aquellos que presentan brote muy abundante o muy sangrante o los que, junto con la verruga, desarrollan alguna complicación intercurrente de cierta gravedad o los que ingresan con el cuadro de la fiebre grave de Carrión.

Se requlere, pues, de larga práctica para observar un número relativamente considerable de niños enfermos que puedan servir para hacer generalizaciones acerca de los caracteres y evolución de la enfermedad en la etapa de la infancia.

De los 50 enfermos, 29 fueron varones y los 21 restantes mujeres, lo que significa un predominio del sexo masculino que alcanza al $58 \%$ contra $42 \%$ de hembras.

En nuestro servicio del Hospital del Niño hemos visto verrucosos de todas las edades, desde 3 .meses hasta 12 años, según puede apreciarse en el siguiente cuadro: 


$$
\text { CUADRO NO } 1
$$

INCIDENCIA DE LA VERRUGA SEGUN LA EDAD

\begin{tabular}{lcc}
\hline \multicolumn{1}{c}{ Edad } & $N^{\theta}$ de entermos & Porcentaje \\
\hline Menores de 1 año & 7. & $14 \%$ \\
De 1 a 2 años & 7. & 14 " \\
D 3 a 5 años & 12. & $24 \%$ \\
De 6 a 12 años & 24. & $48 . "$ \\
\hline
\end{tabular}

De los 50 niños carriónicos atendidos, curaron o fueron retirados en buenas condiciones 42 , habiendo fallecido 8 , lo que arroja un índice de letalidad de $16 \%$, cifra inferior al término medio de la mortalidad de los niños hospitalizados por todas las demás carusas, la que alcanza al $19 \%$ de los asistidos. Este hecho, muy significativo, demuestra la benignidad de la enfermedad de Carrión en la infancia.

No obstante el reducido número de enfermos en las distintas edades vamos a analizar los índices de mortalidad.

$$
\text { CUADRO } \mathrm{N}^{\circ} 2
$$

MORTALIDAD POR VERRUGA EN FUNCION DE LA EDAD

\begin{tabular}{cccc}
\hline Edad & Hospitalizados & Muertos & Porcentaje \\
\hline Menores de 1 año & 7. & 1. & $14,3 \%$ \\
De 1 a 2 años & 7. & 1. & $14,3 \ldots$ \\
De 3 a 5 años & 12. & 2. & $16,6 \ldots$ \\
De 6 a 12 años & 24. & 4. & $16,6 \ldots$ \\
\hline \hline
\end{tabular}

Si tenemos en cuenta que el índice de letalidad de los niños de 0 a 1 año hospitalizados desde 1940 al 48, alcanzó la enorme cifra de $36,7 \%$ y que en los verrucosos de la misma edad fué tan sólo de 14\%, necesariamente debe admitirse que en los lactantes la mortalidad por verruga no es elevada.

Procediendo con igual criterio para los niños de 1 a 2 años, cuyo índice letal fué de $23 \%$, el de los verrucosos ton sólo es de $14 \%$. 
Con criterio estadístico podemos afirmar que la verruga, en esta edad, tiene una evolución forvorable aún que ofrece mayor mortalidad qu en primer año de vida.

El índice letal de los niños hospitalizados de 3 a 5 años ha sido de $12 \%$. La verruga evolucionondo en criaturas de 1déntica edad arrojó 16,6\% cifra superior a la media general. En fin, en los niños de 6 a 12 años, la mortalidad en el hospital fué de $20 \%$; en los verrucosos del mismo grupo fué solamente de $16,6 \%$.

Por consiguiente, la edad preescolar es la más peligrosa en la evolución de la enfermedad de Carrión. Comparando estas cifras con las del adulto, que son de $22,5 \%$ para los varones $y$ de $9,26 \%$ para las mujeres, con una media aritmética de $15,7 \%$, según los datos estadísticos proporcionados por ARANA ${ }^{\text {BO }}$ en los hospitales de la Sociedad de Beneficencia Pública de Lima resulta que la bartonelosis de los niños mayores de 5 años arroja una mortalidad un poco más elevada que la de los adultos, mientras que en los niños pequeños es menor.

No obstante que la verruga en las zonas endémicas es más frecuente en los niños que en los adultos; su estudio en qquella etapa de la vida no. ha despertado en los investigadores el debido interés, pese a que si se revisa cuidadosamente la casuística de las principales obras sobre la materia, se tropieza constantemente con casos ocurridos en la niñez. De las 7 observaciones de la tesis de Salazak ${ }^{61}, 2$ son de niños; en los opuntes dejados por Daniel Carrión, que fueron publicados por sus compañeros de promoción: C. Medina, E. Mestanza, J. Arce, M. Alcedán, R. Miranda y M. Montero ${ }^{62}$ sobre 9 historias clínicas, 4 son de menores de 14 años; ODRIOZOLA ${ }^{2}$, en su clásica obra, de las 17 observaciones que ilustran el texto, 3 corresponden a niños; en la obra de Strongto 4 de las 9 historias clínicas publicadas son de niños menores de 14 años, y de ellos 2 no habían alcanzado el segundo año de vida. Podríamos multiplicar los ejemplos, dejando constancia al mismo tiempo que ninguno de los verrucólogos ha sido pediatria. Lo dicho es suficiente para reforzar nuestra tesis sobre la verruga como enfermedad fundamentalmente infantil.

Contemplada desde un punto de vista general la marcha clínica de la enfermedad de Carrión en los niños, sobre todo de la primera infancia, se puede notar cierta semejanza con la verruga experimental: rareza del síndrome anemizante maligno que da in- 
dividualidad a la fiebre de Oroya, benignidad de las manifestaciones, evolución más precoz y constante de la erupción, y bajo índice de mortalidad.

En cuanto a la enfermedad misma, varía en función de la edad. Se han señalado casos de verruga congénita, cuyo curso depende más del estado de la madre o, mejor dicho del período evolutivo de la enfermedad durante la preñez, que de las condiciones reaccionales propias del niño.

Para mayor clóridad expositiva, describimos en primer término los caracteres de la verruga congénita, luego, las manifestaciones clínicas de la enfermedad en la primera y segunda infoncia ilustrando las descripciones con los casos más típicos que hayamos observado.

No trataremos de la enfermedad de Carrión en la adolescencia porque en esta etapa de la vida la marcha clínica es enteramente análoga a la que presenta en el adulto.

\section{VERAUGA CONGENITA}

En el notable estudio sobre verruga efectuado por SALAZAR ${ }^{61}$ el año 1858, llama la atención sobre la transmisión de la enfermedad por herencia, expresándose textualmente así: "El principio que determina la enfermedad no respeta edad, sexo ni raza, acomete una sola vez en la vida y se transmite por herencia como lo prueba un aobservación del Dr. Ríos en la que la madre atacada de verrugas murió después de dar a luz un niño en el que apareció pocos días después de su nacimiento dicha afección $\theta$ igualmente murió".

Odriozol ${ }^{2}$ cita una observación de Samuel García según lá cual una parturienta en plena erupción verrucosa dió a luz un niño que presentaba un brote análogo. Una de las verrugas, per: fectamente característico, asentada a nivel de la nalga.

La contribución más imporlante al conocimiento de la verruga congénita ha sido hecha por Malpartid ${ }^{163}$. Vamos a presentar sintéticamente dicha observación:

Una gestante joven contrajo la entermedad do Carrión. Al séplimo mes del embarazo presentó esscalofrio y liebre durante. Ics 10 días que precedieron a su carto prematurs. Durante el puerpuerio, la enferma se puso alarmantemente pá- 
lida. Un hemograma sfoctuado al quinto día puso de manifiesto la existencia de Bartonelas en la sangre, desarrollarido el cuadro clínico lípico de la fiebre grave de Carrión. Los hemalíes que a su ingreso a la. Malernidad alcanzaban la cifra de 4'180,000, descendieron diez días después a 1'160,000. La grarvedad de la enferma hacía temer un desenlace fatal. Sin embarigo; 'a las 48 horas de haberse tomado la muestra de sangre cuyo recuento acusó algo más de 1 millón de hemalies, la paciente comenzó a mejorar rápidamente. A los 18 días de iniciada la enfermedad, las bartonellas desaparecieron, los eritrocilos subieron a 3'550,000, con buen estado general.

Mientras la madre desarrollaba este cuadro clínico aqudo, el niño, prematuro de 2,800 gramos de peso y $46 \mathrm{~cm}$. de talla, parecía estar sano. Al $14^{\circ}$ día se le nola decaído y pálido. Un análisis de sangre puso en evidencía anemía intensa pues los hematíes solo llegaban a 1'830,000; con 27,000 leucacitos. El 90\% de los glóbulos rojos estaban parasitados por Bartonellas, pudiéndose contar hasta 13 elo menlos baciliformes en algunos hematíes. La palidez se acentuó al día s!guiente, apareció tinte ictérico en las conjunlivas, el niño entró en prolunda adinamia, con rechazo de alimentos y fiebre, falleciendo 48 horas después.

Este caso, único que se registra en la literatura médica nacional justificaría la afirmación de ODRIOzOLA ${ }^{2}$ de que "los recién nacidos en general, son gravemento atacados por la eniermedad; la fiebre grave de Carrión, sobre todo, es inexorable con ellos".

No ocurre lo mismo con los recién nacidos de madres que se encuentran en el período de regresión del brote. A este respecto: en mi práctica privada pude observar un caso que me cermite hacer esta aseveración.

En el año 1929 alendí dos niños procedenles de Caraz con enfermedad de Carrión en pleno periodo eruptivo. La madre, embarazada do seis meses, rambién presentaba brote de verrugas. El parto a férmino se realizó durante la regresión de la erupción sin ninguna incidencia, y el niño, de buen esiado general, nació indemne, no habiendo presentado manifestación alguna de Bartonelosis duranle sus tres primeros meses de vida, época hasta la cual lo pudimos seguir, perdiéndolo luego de visla porque la familia regresó a la ciudad de Caraz.

Las observaciones precedentes, aunque muy escasas, son bastante demostrativas: la enfermedad de Carrión se presenta en forma congénita en determinadas circunstancias. Durante el período peeruptivo (fase hemática de Weiss), cuando las fuerzas inmunobiológicas maternas aún no hon logrado domina̛r la infección, el recién nacido desarrolla el cuadro de la fiebre grave de Carrión, tal como se presentó en el caso de Malpartida ${ }^{63}$. Cuando la madre está en el período eruptlvo, el niño puede nacer con el brote correspondiente, como los casos de Ríos y Samuel García; en fín, si la madre está en el período de regresión del brote, el niño nace indemne, como lo hemos verificado nosotros. 
En lo que se refiere al mecanismo fisiopatológico de estas formas congénitas, creemos que la infección es transplacentarta, operóndose a través de minúsculas rupturas de las vellosidades placentarias, y el consiguiente pasaje do la sangre materna infectada al torrente circulatorio del feto.

\section{CONSIDERACIONES SEMIOLOGICAS}

Como elemento informativo previo al estudio nosográfico y clínico de la enfermedad de Carrión en la infancía, consideramos conveniente puntualizar los síntomas más constante que pueden servir para caracterizarla.

De acuerdo con las observaciones que sirven de base a este estudio, hemos establecido la frecuencia porcentual de los síntomas. No señalamos aquellos que se observan en menos del $50 \%$ de los casos por considerarlos, después de atento análisis, como síntomas dependientes de síndromes anatomoclínicoš de localización del proceso reaccional en determinado sector de la economía, en tanto que los que se presentan en mayor proporción constituyen un exponente de la respuesta general del organismo ante el propio proceso infeccioso. De acuerdo con este criterio, podemos esiablecer el siguiente cuadro:

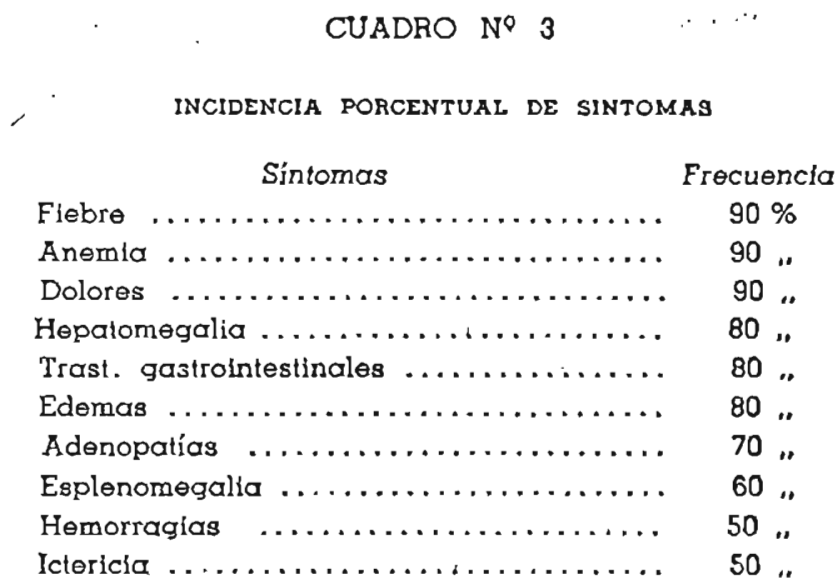

A este grupo de síntomas debe agregarse dos signos que tienen carácter patognóstico: la presencia de Bartonellas en la sangre 
o en los tejidos y la erupción verrucosa. Estos signos no siempre se descubren en el momento del examen pero, cuando se observan, definen la enfermedad, aún en ausencia de todos los otros.

Los demás elementos sintomáticos tienen un valor relativo, siendo de extraordinario interés el dato concemiente a la procedencia del enfermo, el que no debe omitirse en la anamnesis.

Como se aprecia en el cuadro $\mathrm{N}^{\circ} 3$, tres son los síntomas más constantes: fiebre, anemia y dolores. Esta triada sintomática no tiene nada de característica por observarse en un gram número de enfermedades.

La fiebre fué objeto de la mayor atención de los clínicos de fines del siglo pasado, baste señalar las denominaciches de "fiebre de Oroya", "flebre grave de Carrión", etc. Mimbela ${ }^{64}$ hizo un prolijo estudio de las curvas térmicas en la verruga sin poder señalar ningún tipo característico. Odrrozol a asevera que "la fievre ne manque jamais". En las formas agudas iniciales con gran anemia, suele ser elevada, mientras que en las formas leves se observan alteraciones febriles ligeras. Generalmente, las elevaciones térmicas, precedidas de escalofrío y malestar, son vespertinas con remisión matinal. En la mayor parte de casos son diarias, en otros interdiarias o irregulares. Desaparece cuando el brote verrucosa se constituye denifitivamente.

La anemla es constante, varjando de intensidad de acuerdo con la evolución de la enfermedad. Ligera y simple en los casos leves, es intensísima, tal vez es la enfermedad que produce más rápida desglobulización en los casos de período preeruptivo de marcha aquda, tomando el tipo pernicioso. Cuando la erupción es abundante, las hemorragias determinadas por escoriación de las verrugas, pueden determinar anemia de clerta gravedad.

De la misma manera que la flebrə embargó las actividades de los médicos a fines del siglo XIX, la anemia ha sido y continúa hasta la fecha siendo objeto de estudios muy cuidadosos, por ser el síntoma más importante de la fiebre grave de Carrión.

TAMAYo' ${ }^{65}$, el año 1898, dió a conocer las principales características hematológicas de la enfermedad de Carrión, poniendo de relieve la rapidez en el desarrollo de la anemia, las modificaciones en el volumen globular y la frecuencia de la leucocitosis. Hercelles ${ }^{66}$, por la misma época, llamó la atención sobre la microcitosis. 
Biffi y Gastiaburútir fueron los primeros en poner de relieve la existencia de hematíes nucleados: normoblastos y megaloblastos en la somgre periférica de los carriónicos. Algunos años más tarde, Gastiaburú y Rebagliati ${ }^{41}$ describen como elemento constomte en la anemia de los verrucosos, hematíes granulosos y normoblastos; y, en los casos de alta gravedad, la presencia de megaloblastos que interpretan como un retorno de la médula al estado embrionario. Clasifican como de tipo pernicioso progresivo la anemia de la enfermedad de Carrión. En el mismo trabajo señalan la presencia de Bartonellas en el período eruptivo.

Un ar̃o más tarde, MonGeres hace el primer ensayo sistemático de la hemakslogía de la enfermedad que nos ocupa, confirmando la existencia de normoblastos y megaloblastos según la intensidad de la anemia, y llamando la atención sobre la frecuencia de alraciones hemáticas consistentes en la presencia de anisocitosis, policromatofilia y eritrocitos granulosos en lạ.sangre periférica y aumento frecuente del valor globular. Como modificaciones leucocicitarias, encontró polinucleosis. En exámenes seriadoc pudo poner de manifiesto lo que llamó "crisis hemática". caracterizada por aumento de los monocitos y presencia de eosinófilos, como elementos precursores de la convalescencia y la proximidad del período eruptivo. Basado en estos hallazgos, dió las pautas para formular el heinodiagnóstico y el hemopronóstico de la enfermedad de Carrión.

El propio MONGE ${ }^{70}$, el año 1912, describió un elemento, el mielocito basófilo de protoplasma homogéneo en la sangre periférica. cuya presencia significa un signo de pronóstlco casi siempre fatal de la enfermedad.

Inspiróndose en los estudios hematológicos anteriores, ARCE ${ }^{71}$ define las repercusiones clínicas de la oligocitemia: en la forma maligna de la enfermedad, en la que la anemia es de tipo pernicioso y progresivo con presencia de megaloblastos como elementos característicos, mientras que en la forma benigna o eruptiva dichos elementos no suelen encontrarse en la sangre.

Por primera vez, WeIss ${ }^{72}$, el año 1925, se refiere al papel que juega el sistema retículo endotelial en la bartonelosis, indicando al mismo tiempo la frecuencia de complicaciones secundarias que no siempre se reflejom en las fórmulas sanguíneas, no obstante que, puede advertirse a menudo en tales casos cierto grado de leucocitosis. 
Monge y Weiss ${ }^{73}$, en un importante trabajo, precisan los caracteres de la anemia carriónica, cuyn evolución se realiza con impresionante rapidez $\theta$ intensidad siendo siempre de carácter fuertemente regenerativo, con presencia de elementos embrionarios de tipo megaloblástico. Se acompaña de reacción de la serie blanca constituida por leucocitosis leucemoide, o, mejor dicho, leucoanemia, pues se comprueban numerosos elementos blancos jóvenes o inmaduros, pudiéndose observar algunas veces lá presencia de células primordiales parenquimatosas indiferenciadas.

El estudio hematológico más completo ha sido efectuado por Hurtado, Pons y Merino48, del que se desprende que la anemía es frecuente y severa, de gran rapidez en su desarrollo en los casos agudos en los que:se comprueba notable destrucción globular $y, a l$ mismo tiempo, intenso esfuerzo regenenativo. Morfológ1. camente considerada es de tipo macrocítico e hipocrómico. Pese a la oligocitemia, la volemía se mantiene dentro de límites normales por aumento compensatorto del plasma.

En lo que a la fórmula leucocitaria se reflere, establecen que la "crisis hemática de Monge" corresponde al momento en que desaparecen las bartonellas do la sangre periférica al examen directo. Robustecen la opinión de WeIss ${ }^{72}$ en el sentido de la imposibilidad de fundamentar el pronóstico en la fórmula leucocitaria por el frecuente desarrollo de lesiones secundarias.

Afirman la existencla de bilirrubinemia, descrita anteriormente por Weiss ${ }^{72}$ y por GuZMÁn ${ }^{101}$ y demuestran la existencla de hipoclorhidria y en algunos casos aquilia gástrica de tipo verdadero.

Los resultados hematológicos obtenidos en nuestro servicio por Vilchez Lozada, Jefe del Laboratorio de nuestra clínica, concuerdan con los obtenidos por Hurtado y colaboradores. Las características hematológicas de la enfermedad de Carrión en los niños son semejantes a las que se observan en el adulto. La rapidez regenerativa, notable ya en el adulto, es mucho más vigorosa en el niño.

Durante la erupción, la anemia es discieta e hipocrómica. En los niños puede tornarse de clerta intensidad como consecuencia de hemorragias profusas debidas al desgarro y estallido accidental de las verrugas. 
Los dolores constituyen el tercer elemento casi constomte en la enfermedad de Carrión. Son precoces en su aparición. No respetan ni el día nt la noche, asentando de preferencia en las articulaciones, los huesos y las masas musculares. Unas veces son intensos, otras tolerables, pero slempre molestosos.

En los lactantes se manifiestan por intranquilidad, desasociego, llanto y trastornos del sueño, prestándose a confusión con el signo de Sisto de la lúes congénita. Los niños mayores describen sus sensaciones dolorosas que presentan los mismos caracteres que se observa en el adulto. Asientan de preferencia en las articulaciones de las extremidades en donde asumen el tipo reumatismal; en las masas musculares afectom los caracteres de calambres, aumentando de intensidad durante la noche. En algunos casos los dolores son erróticos, con predilección individual por ciertas regiones.

Al comienzo del brote, se intensifican a veces, para desaparecer cuando la erupción es abundante. La cefalalgia es la regla en los niños mayores.

En los casos leves, las manifestaciones dolorosas suelen pasar desapercibidas, lo mismo que la fiebre y la anemia, en cuyo caso la erupción es el único síntoma de la enfermedad. En los lactantes y niños pequeños, con mucha frecuencia se presentan estos casos.

Los fenómenos gastrointestinales son bastante comunes y precoces en su aparición, afectando en los lactantes el tipo de la dispepsia simple con su cortejo sintomático habitual: vómitos, elevación de temperatura, anorexia y dentención de la curva ascencional del peso. Otras veces, pero con menor frecuencia, desarrollan un cuadro de enterocolitis mucohemorrágica.

Estos fenómenos gastrointestinales son más discretos en los niños mayores, manifestóndose bajo la forma de vómitos, anorexia y estreñimiento. Estos síntomas que reputaban antiguamente como signos de embarazo gástrico febril, son de tal constancia que Arce ${ }^{25}$ decía, refirténdose a los adultos, "que los pacientes creyéndose "empachados" solicitan con frecuencia la administración de un purgante". Raro ha sido el niño mayor de 3 años, que hemos atendido, en quien la familia no haya comenzado el tratamiento con tal medicación.

El hígado suele estar hipertrofiado, algunas veces doloroso. OdRIOzol $\mathrm{A}^{2}$ ha verificado la hepatomegalia en casi todas sus ob- 
servaciones. Arce 25 afirma que en los casos exentos de complicación no se presenta hipertrofia hepática. En los niños, nosotros la hemos camprobado en la gran mayoría de verrucosos.

También son frecuentes los edemas. Durante la iniciación del brote, constituyen la regla, observóndose tormbién en el período preeruptivo. Asientan sobre todo en las extremidades inferiores, pudiendo comprobarse en las manos y párpados. Los pocos casos exentos de edema han sido aquellos que ingresaron a nuestro servicio en el período de regresión del brote.

Los infartos ganglionáres se presentan con bastante constomcia. Probablemente su incidencia es mayor que la que hemos señalado por omisión en consignarla en las historian clínicas que hemos revisado. Odriozola ${ }^{2}$ señala este síntoma como muy valioso en el diagnóstico diferencial con la malaria.

ARCE ${ }^{26}$ afirma que siempre ha encontrado infartados los ganglios, tanto en la forma benigna como en la verruga maligna. Es un síntoma precoz que se puede observar desde el período de invasión, cicompaña la enfermedad al principio del brote y desaparece gradualmente en el período de seca. Algunas veces se observa micropoliadenia generalizada; otras son ganglios regionales los que se infartom. Slempre son indoloros y sin reacción periadenítica.

No obstante negar ARCE$^{25}$ la existencia de megaloesplenia, por lo menos la mitad de nuestros enfermos la presentaron. En algunas de las historias recogidas por Strong ${ }^{40}$ se señala la existencia de esplenomegalia. En nuestro serviclo, Cachay Díaz estudió un caso de síndrome de Frugoni de origen carriónico. WeINMAN ${ }^{42}$ sostiene que duramte la erupción se reducen las dimensiones de! bazo.

Los enfermos presentan hemorragias diversas, siendo las más frecuentes las epístaxis y las petequias. Uno de nuestros pacientes presentó hematuria, sin compromiso renal. En pleno período eruptivo, las verrugas, por su constitución anatómica, sangran con gran facilidad.

En fin, la ictericia se observa en los casos de intensa onemia y algunas veces en el período eruptivo con anemias discretas. 


\section{ASPECTOS NOSOGRAFICO Y CLINICO DE LA VERRUGA EN EL NIÑNO}

La verruga en la infancia ofrece caracteres particulares, tanto por su benignidad cuanto por su rápida evolución hacia el brote. Pocas veces aiecta el tipo de la fiebre grave de Carrión. A medido que los niños crecen, la enfermedad va tomando los perfiles que presenta en el adulto.

Desde el punto de vista nosográfico, su evolución se opera en forma un tanto análoga a la de las enfermedades eruptivas, con la diferencia de que los períodos de invasión, brote y regresión son mucho más prolongados. Se puede considerar en la enfermedad de Carrión cuatro períodos: incubación, invasión o preeruptivo, erupción o brote y regresión o secá.

El peroído de incubación, como en casi todas las enfermedades, es silencioso, comprende el tiempo que se extiende desde la penetración del agente infeclante, la Bartonella, hasta su adaptación al organismo, momento en el que aparecer los primeros síntomas clínicos.

No es posible fijar con exaclitud la duración de este primer período. Para Odriozor. ${ }^{2}$ sería de 15 a 40 días; $A_{\text {RCE }}^{26}$ cree que puede extenderse desde 12 días hasta 8 meses. El criterio más seguro para fijarlo es el adquirido en las inoculaciones "in anima nobilis". Entre ellas podemos citar las siguientes:

1 ' Carrión, incculándose sangre de botón verrucoso, tuvo un período de incubación de 21 días;

$2^{9}$ García Rosell, par inoculación accidental de sangre de un enfermo de fiebre grave de Carrión, presentó los primeros síntomas a los 20 días; y

$3^{\text {? }}$ Kuczynski Godard, inoculándose cultivos virulentos, manifestó los primeros sufrimientos a los 17 días.

Por otra parte, las inoculaciones practicadas a animales, pueden también servir de criterio informativo a este respecto. Haciendo un promedio aritmético, la verruga experimental del animal tiene una incubación de 15 días.

Basándose en todos estos datos, puede admitirse con cierta exactitud que el períado de incubacićn de la verruga peruana es de 2 a 3 semanas, siendo este tiempo más constante en los niños que en los adultos en quienes puede prolongarse por mucho mayor tiempo. 
Los síntomas del período de invasión a preeruptivo son insidiosos y nada específicos algunas veces. En la primera infancia hemos atendido casos en los que han pasado completamente desapercibidos. He aquí un ejemplo:

Observación No 1.-El niño C. M. E. de 8 meses de edad. Historía clínica $N^{0} 131$ que procede de zonoverrucosa, ingresa a nuestro servicio sin haber presentado otra manilestación clínica que un llorido brole de verrugas, muy sangrantes, motivo por el cual solicitaron su hospitalizazión. Aparte de infartos ganglionares cervicales y crurales y discreta anemia cle 3'600,000 hematíes, toda su enfermedad consistia en el brole verrucoso que interesaba las extremidades, nalgas y cara. Las verrugas eran de lipo miliar. Fué dado de alta unas semanas más árde cuando las verrugas comenzaron a regresionar.

Otras veces, y esio es lo más frecuente, la enfermedad se anuncia con malestar, infronquilidad, llanto, anorexia, vómitos, diarrea, elevación de temperatura, palidez, sudores y irastornos del sueño. El desasociego, los gritos, el llanto y el insomnio contituyen las manifestaciones objetivas del dolor. En algunos enfermitos se pueden comprobar petequias en distintas partes del cuerpo, y epístaxis. Al examen clínico: palidez de piel y mucosas, infartos ganglionares, algunas veces hepatomegalia, con menor frecuencia megaloesplenia. El examen de sangre revela una onemia discreta de 3 a $3^{1 / 2}$ millones de eritrocitos y de 10 a 12 gramos de hemoglobina.

Dos eventualidades evolutivas pueden entonces presentarse: intensificación de la anemia o aparición de la erupción. En el primer caso, los enfermos decaen día a día, la fiebre persiste acompañándose de escalofrío y sudores, y lo que más alarma al clínico es la anemia rápidamente progresiva. Cuando adquiere cierta intensidad, el examen directo de la sangre permite descubrir la existencia de Bartonellas. Tal el caso śguiente:

Observación $\mathrm{N}^{\circ}$ 2.-A S. M. de 9 mesos, fuó hospitalizado el 12 de abríl de 1948 en la cama $N \$ 125$ de nuestro servicio. Historia clínica $N^{\circ} 12381$. Nacido a término y criado con lactancia materna 5 meses. luego lactancia mixta. Procede de Yungay. Ocho días antes de hospitalizarse presenta intranquilidad, fiebre, palidez, vómitos biliosos y orinas oscuras. Al examen: intensa palidez de piel y mucosas, poliadenia generalizada, hígado grande, gran esplenpmegalia (el polo inferior del bazo a $3 \mathrm{~cm}$. de la cresta iliaça), duro y homogéneo. Temperalura subísbril. Peso 7,800 gramos. 
Análisis de sangre: Hematíes 900,000. Leucocitos 45,600. Presencia de abundantes bartionellas de forma bacllar. Indice parasitario: $93 \%$. Polinucleares neltrófilos 80\%; Linfocitos 18\%; Monocltos 2\%. Normoblastos 30\%; Megaloblastos $1,5 \%$. Anisocitosis polkilocitosis y anisocromia.

Sometido a tratamiento con estreptomicina 4 días más tarde solo restan algunas escasas bartonellas cocoides en los hematies los que ascendieron a 2'800,000. Diez días después, desaparición completa de las bartonellas de la sangre y 3'240,000 glóbulos rojos. La cifra leucocitaria se normaliza, arrojando el recuento diferencial $4 \%$ de eosinófilos, $40 \%$ de neutrólilos; $36 \%$ de línfoclios y $20 \%$ de monocitos. Al proplo tiempo el bazo e hígado recobran sus dimensiones normales, persistiendo la poliadenia. El enfermo apirético y con buen estado general, es dado de alta $\sin$ erupción.

Estos casos corresponden a la fiebre grave de Carrión o fiebre de Oroya o verruga de forma maligna de Arce, fiebre anemizante grave de Carrión o fase hemática de la Verruga de Welss. Lo que más llama la atención en estos casos es la brusquedad de la anemia que, con la misma facilidad con que se establece, desaparece rópidamente cuando mejora el enfermo. La reparación hemática es tan rápida que Wiess 75 dice: "la remisión şanguínea se realiza con notable rapidez, tanto que al hacer los recuentos globulares diarios, cuando ella se inicia, da la impresión de que un freno que obstruía la hematopoyesis hubiese sido quitado bruscamente".

En los niños mayores, cuando la enfermedad asume este carácter, suele ser más grave. Consideramos de interés dar a conocer los sigulentes casos observados en niños maryores:

Observación $N^{\circ}$ 3.-I. A. C. 5 años. Ingresa a nuestro servicio el 9 de mayo de 1939. Historia clínica $\mathrm{N}^{\otimes}$ 466. Habitando una zona verrucosa, cae enfermo diez días antes de su hospitalización, con profundo malestar, escalofrío solemne con elevación de temperatura por encima de $39^{\circ}$ y remisión matinal $\alpha 37^{\circ} 2$, dolores ostecarticulares muy intensos y dífusos, cefalea pertinaz y vómitos biliosos. Día a día palidece en forma ostensible. Nada, absolutamente nada al examen físico. El examen de sangre da el siguiente resultado: Hematíes 800,000; Leucocitos 14,200 Polinucleares neutrófilos $78 \%$; Linfocitos 18 y Monoclos $4 \%$. Normoblastos $8 \%$. Anisocitosis y policromatofilia. Abundan:e bartonellas bacilares y cocoides. Permanece en nuestro servicio solamente tres días, en las mismas condiciones, siendo refirado por voluntad de los familiares para llevarlo a Anasmoryo (quebrada verrucosa vecina de Huaral), por ser creencla popular que los carriónicos curan en los lugares donde adquieren la enfermedad.

Observación $N^{9}$ 4.-F. M. de 7 años. Se hospitalizó en nuestro serviclo el 2 de setiembre de 1937. Historia clínica $N^{\circ}$ 132. Procede de Ancón pero una vemana anies de caer enfermo estuvo de visita en el caserío de Acos, quebrada 

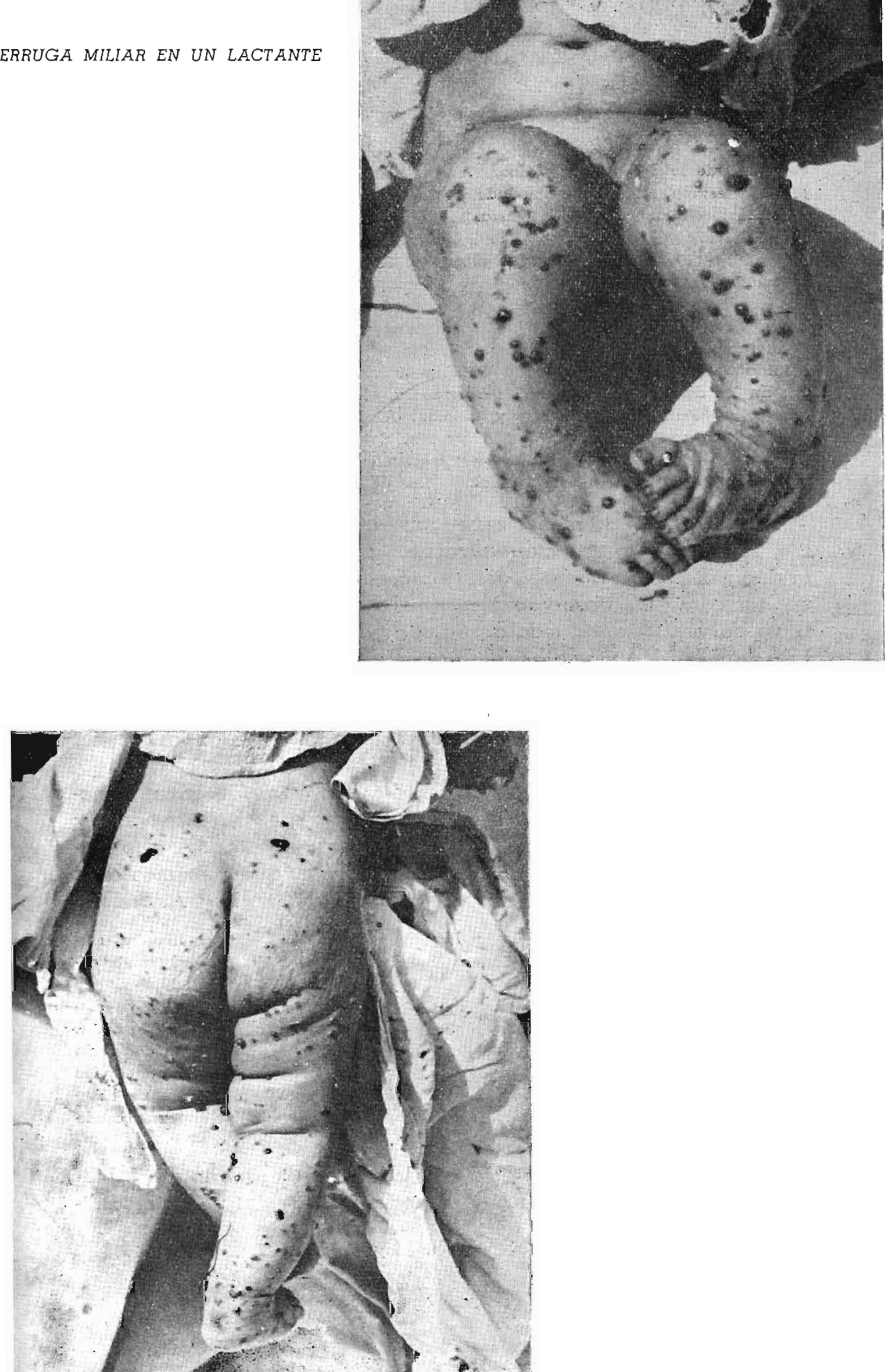
verrucosa de la provincia de Canta. A su regreso, donde solo permaneció 7 días, el niño estaba intensamente pálido y demacrado, presentando 4 días después escalofrío, cefalalgia, fiebre y epístaxis. La temperatura se eleva diariamente en las tardes a cerca de $40^{\circ}$ para remitir ligeramente en las mañanas, durante todos los días que precedieron a su hospitalización. Al examen, el niño está muy pálido. anhelante, las conjuntivas subicléricas, los párpados edematosos. Micropoliadenia cervical y supraclarvicular, lengua seca y saburrosa, ligeras hepato y esplenoraegalia. Al examen de sangre: 1'100,000 hematies y 5,400 leucocitos. Gran cantidad de Bartonellas baciliformis. Indice parasitario $80 \%$. $2 \%$ de megaioblastos. Hemoalobina 6,78 gramos. Reacción de Widal negativa.

En los días sucesivos el enfermo empeora, el hígado y el bazo aumentan do tamaño, presenta diarrea profusa y edemas. Albúminas plasmáticas 5,70 gramos. Serina 2,62 gramos. Globulina: 3,08 gramos. Orina: 0,60 gramos de albúmina y presencia de kiobilina. Los hematies descienden hasta 917,000, el paciente se agrava, falleciendo en anasarca a los 16 días de hospitalizado.

En los casos de menor severidad, después de un tiempo variable, sobreviene la erupción verrucosa. El lapso comprendido entre la anemia intensa que a veces se presenta en el período preeruptivo, tal como las observaciones que acabamos de señalar, y el brote de verrugas, ha sido designado por OdRIozol ${ }^{2 i}$ con el nombre de periodo intercalar, el que, según nuestras observaciones, se prolonga tanto más cuanto más intensa es la anemia y más grave el estado general. Weiss ${ }^{15}$ lo señala con el nombre de fase histioide sin erupción macroscópica, siendo extraordinariamente rico y polimorfo en síntomas clínicos.

Es precisamente en este momento evolutivo de la enfermedad cuando la situación del enfermo asume mayor gravedad y cuando las complicaciones suelen ser más frecuentes. A este respecto vamos a presentar un interesante caso que debemos a la cortesía de nuestro distinguido colega y amigo Dr. Luis A. Suárez.

Observación $N^{0}$ 5. - La niña R. M. T. de 11 meses de edad ingresa al servicio del Dr. Suárez del Hospital del Niño el 2.5 de mayo de 1946. Historía clínica $N^{\circ} 2589$. Cuatro meses presentó un cuadro anemizanle fébril acompañado de Iraslornos dispépticos que curó. El 10 de mayo nuevamente fué acomelida de dispepsia con vómilos, fiebre, anemia y signos de deshidratación. Peso: 7,450 gramos. Análisis de sangre: Hematíes 2,300,000. Sin Barlonellas. Mejora de la dispepsia tóxica y desarralla pielitis, a la que sucedió una bronconeumonia, enfermedades que curaron con tratamientos adecuados. En plena convalescencia, hace un brote verrucoso en los primeros días de Julio, siendo dada de alta en buenas condiciones al finalizar el mes de Agosto.

En esta historia se aprecia claramente la exiraordinaria labilidad de los carriónicos durante el período intercalar. Esta modali- 

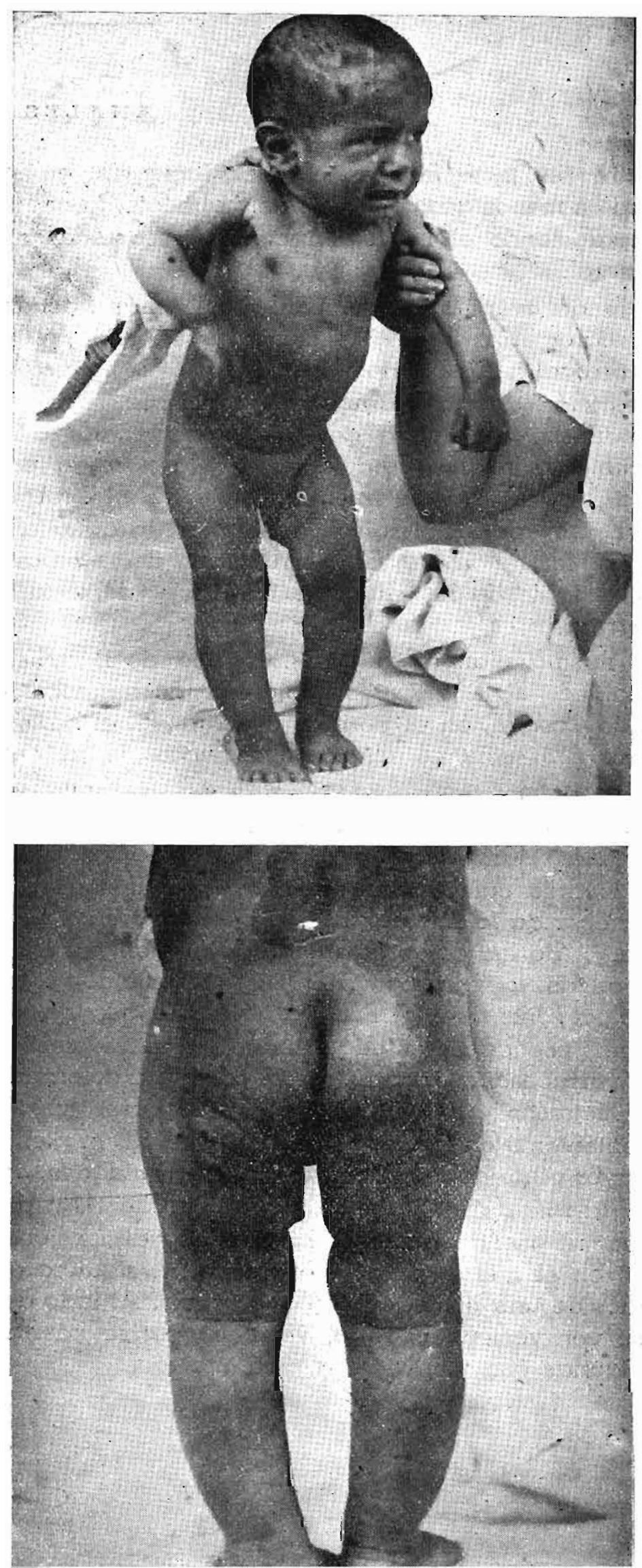
dad evolutiva es poco frecuente en los lactantes, en los que la enfermedad es menos accidentada habitialmente, la anemia menos intensa, apareciendo el brote con cierta precocidad y con buen estado general.

La segunda eventualidad con mucho la más frecuente en los niños, se caracteriza por el pasaje del período preeruptivo al brote de verrugas. El período preeruptivo, o de invasión, termina con la aparición de los granulomas verrucosos que constituyen el tercer período, o eruptivo de la enfermedad de Carrión. Un carácter clínico distingue completamente la verruga peruana de todas las fiehres eruptivas: mientras en éstas el brote se revela por exacerbación de los síntomas generales, en aquella sucede lo contrario: la aparición de los verrucomas tiene lugar con una mejoría apreciable de los síntomas clínicos y del estado general de los enfermos.

De la misma manera que la presencia de Bartonelias en la sangre establece el diagnóstico etiológico inconmovible de la enfermedad de Carrión, en el período preeruptivo, el brote de verrugas constituye el síntoma clínico inequívoco de la enfermedad.

Sobre la piel levemente edematizada en un punto circunscrito, aparece una pequeña mácula rosada, de forma circular, de un color aiso más claro que las petequias comunes, que tiende a crecer y elevarse como una pequeña papulita semiesférica roja, la que al crecer da la impresión, según la pintoresca comparación de SalazkR ${ }^{61}$ " de las gotas de rocío que se ven por las mañanas en las hojas de las plantas". En su crecimiento, sobrepasa el tamaño de la zona de piel sana que la circunscribe, lo que les da un aspecto pseudopediculado siendo en realidad sesiles las eflorescencias verrucosas. Toman poco a poco una coloración roja intensa, son lustrosas y fluctuantes, indoloras y pruriginosas. Asientan preferentemente en las zonas descubiertas de la piel, localizándose la mayor parte de las veces en las extremidades, en su zona distal y en la raíz de los miembros y en la cara. Su distribución es simétrica, no siendo todas de las mismas dimensiones por no encontrarse en el mismo período evolutivo, ni siquiera en lugares determinados de una misma región anatómica. Al lado de máculas rosadas, se ven vesiculitas rojas, verrugas perfectamente desarrolladas y algunas con tendencia a marchitarse. 
A medida que crecen se hacen más vasculares, distendiendo fuertemente las delgadas capas epidérmicas que las recubren. Es en este moinento que se hacen más pruriginosas. El escozor que provocan induce a rascarse, con lo que se erosionan y sangran, provocando hemorragias, a veces de bastante consideración.

En atención a sus dimensiones, se les designa con los nombres de miliares cuando su diámetro es inferior a $1 \mathrm{~cm}$., nodulares a las que tienen un tamaño comprendido entre 1 y $3 \mathrm{~cm}$. y mulares cuando superan este diómetro.

El tipo que tan sumariamente hemos descrito corresponde a la verruga miliar, la más frecuente, cuya localización es cutónea. Las verrugas nodulares son subcutómeas y se manifiestan desde un principio como eminencias a nivel de la piel, más ostensibles al tacto que a la vista. La piel conserva en un principio su aspecto y color normales, después toma una coloración rosada o violácea. Es sensible al tacto pudiendo prestarse a confusión con el eritema nudoso.

Como ejemplo de verrugas miliares podemos señalar los siguientes casos:

Observación $N^{9}$ 6.-J. R. E. de 3 años ingresa a nuestra servicio en agosto del presente año. Ha sido una criatura enfermiza pues ha padecido de trastornos dispépticos sarampión, bronconeumonía y varicela. Su enfermedad data de hace 6 meses en que, estando en una zona verrucosa de Caraz, presentó un cuadro consistente en flebre continua, pérdida de apetíto, decaimiento y palidez con orinas ascuras. Hasta un mes antes de su hospitalización ha tenido períodos alternativos de mejoría y empeoramiento, hasta que le aparece un abundante brote de verrugas miliares, algunas confluentes, localizadas a nivel de las cuairo extremidades. Fuera de palidez discreta de las conjuntivas, el examen clínico no pone de relieve nada digno de anotarse; llene 3’800,000 hematies con 6.400 leucocitos sin mayor alteración de la fórmula leucocitaria. Toda la enfermedad la constituye el brote.

No siempre la erupción es tan exuberante. A veces es discreta:

Observación No 7.-R. S. R. de 9 meses ingresa a nuestro serviclo el 2 de Junio del presente año. Historia clínica $N^{\circ}$ 12619. Procede del callejón de Huarylas, de donde vino hace cerca de un mes. Solo ha padecido de piodermitis. Algunos días antes de su ingreso presenta fiebre discreta, notándose la aparición de una erupción que sangra al contacto. La niña es pálida. Nada de importancia al examen físico; en las dos mejillas presenta verrugas mlliares. En los miembros inferiores se aprecian también verrugas miliares y nodulares, asentando las primeras, de preferencia, en la región glútea, y las segundas en las plernas. Se 
trata con penicilina, notándosie aue las verrugas disminuyen de tamaño y palidecen. Fué dada de alta por curación el 22 de Agosto.

Algunos nódulos que asientan en el tejido celular subcutóneo son duros y dolorosos, con tendencia a desorrollarse con mayores dimensiones; distienden la piel $y$ adquieren una forma globulosa e irregularmente esférica que crece como verdaderos tumores, constituyendo las verrugas mulares que se localizan de preferencia a nivel de las grandes articulaciones: rodilla y codo.

Nuestro- colega el Dr. Morey, Jefe del servicio de cirugía del Hospital del Niño, nos ha proporcionado dos interesantes observaciones, que agradecemos. Se trata en ambas de verrugas mulares que demandaron intervención quirúrgica.

Observación $N^{\circ}$ 8.-La enlerma A. L. M. de 6 años de edad fué llevada al desartamento de cirugía del Hospital del Niño, el año 1911 por presentar una tumoración irregularmente esférica de color rojo intenso, fluctuante e indolora a la presión, localizada en la rodilla izquierda, de, $6 \mathrm{~cm}$. de diársetro que no impide la marcha y cuya explcración permite comprobar que no es adherente a los planos profundos. La investigación anamnésica pone en evidencia que la niña nrocede de una zona verrucosa y que unos meses antes de su hospitalización estuvo enferma con fiobre, dolores osicoarticulares, cefaleas, palidez infensa y malestar general. El cuadro f́ebril era irregular. En el mes de febrero apareció un nódulo subcutáneo, indoloro, pero molesio, que asentaba en la rodilla y que con el correr del tiempo fué creciendo hasta llegar a hacer hernia al exterior alcanzando las dimensiones anoladas. Dicho tumor al exámen clínico e histológico reunía los caracteres de la verruga mular, habiendo requerldo de la exéresis que f́í ejecutada por el Dr. Morey con todo éxito.

La erupción verrucosa no sólo se localiza en la piel, también puede presentarse en las mucosas, habiéndose descrito algunas veces verrugas en la mucosa nasal y bucal. Con menor frecuencia en la conjuntiva y la córnea, comprometiendo el ojo. Tuvimos ocasión de atender un caso de estos el año 1931, en el servicio de niños del Hospital "Arzobispo. Loayza". Delgado Connejo publicó la historia de un enfermo con verrugas en la mucosa vesical.

La localización laríngea también ha sido señalada, habiendo observado un caso de éstós en nuestro servicio el año 1948, cuya historia es como sigue: 
IVERRUGA MILIAR CONFLUENTE DE LAS EXTREMIDADES
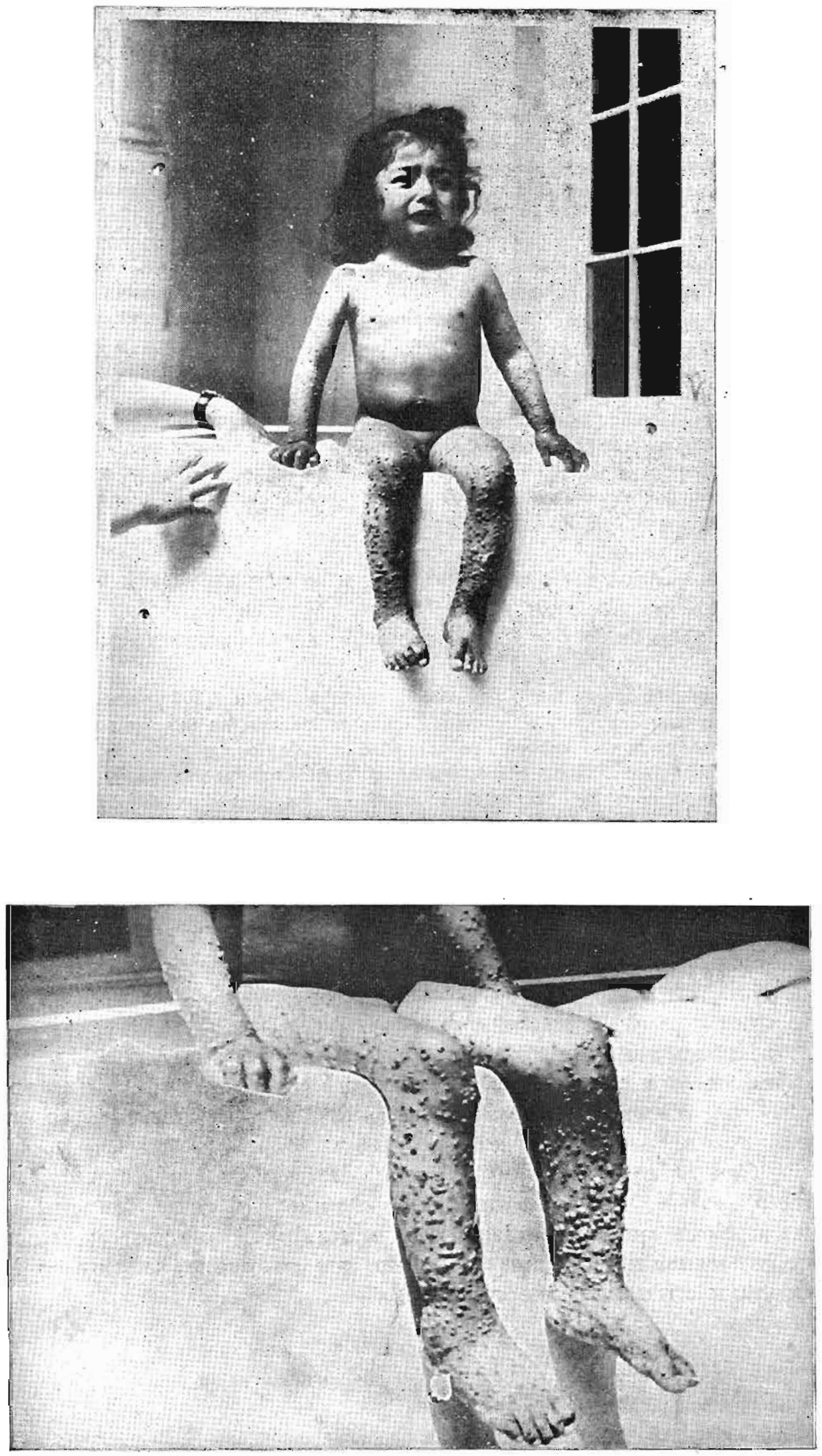
Observación N? 9.-La niña Y. C. de 9 años, ingresó a nuestro servicio el 23-VII-48. Historia clínica $N^{2}$ 11073: Procede de zona verrucosa de Ancash. No se tiene datos precisos del desarrollo de la enfermedad. Cinco diras antes de hospitalizarse hace una erupción verrucosa en el cuello, nalgas y extremidades dislales de los miembros. Al examen: Adenooatía cervical e inguinal discretas, pero dolorosas al tacto, palidez, edema de las extremidades. Nada al exámen estetoacústico, pese a que la enferma tiene tos bitonal. Anemia de 3 millones sin ostensible modificación leucocitaria. Tuberculina positiva. Infiltración hiliobasal derecha a la radiografía. La los se hace pertinaz durante su permanencia en el servicio, aparece disfonía y presenta accesos paroxísticos de cianosis con disnea y esiridor laríngeo. Al examen laringoscópico, tumoración roja, del tamaña de un garbanzo, no ulcerada, movible y pediculada, implantada en la banda aritenoepiglótica derecha. Practicada la exérésis de la tumoración, nuestro patólogo Dr. Mori Chávez comprueba que se trata de un verrucoma laríngeo.

Las disfonia, la tos y las crisis asfícticas desaparecieron y la enferma, en buenas condiciones, fué dada de alta. No obstante tratarse de una niña tuberculosa, la verruga evoluciono favorablemente.

En los niños pueden presentarse erupción universal, fenómeno en verdad excepcional. Se cita en la literatura médica nacional el caso observado por CAMpodónICo ${ }^{77}$, cuyo resumen es:

Niño de $21 / 2$ meses con buen estado nutrilivo. Peso: 5,500 gramos. Procede de la zona verrucosa de Cocachacra. Llama la atención su intensa palidez y la erupción de verrugas miliares ceneralizadas a toda la superficie de la piel y mucosas accesibles: bucal, nasal, ocular, etc. Al examen: hepato y esplenomegalia. Temperatura $38^{\circ}$. El enfermo falleció a los diez días de hospitalizado.

A la autopsia se comprobó erupción verrucosa universal: todos los tejidos de la economía, sin excepción alguna, presentaban la erupción característica. El bazo, anotó Campodónico, parecía "un saco lleno de verrugas".

Este caso, único, pone de manifiesto a la luz de los conocimientos actuales el vigor reaccional del sistema retículo endotelial del niño, y la posibilidad, negada por algunos observadores, de la aparición de verrugas internas.

La erupción verrucosa se presenta en brotes sucesivos, pudiéndose ver que cuando un primer brote se marchita, aparece otro con las mismas características. No todas las verrugas se encuentran en el mismo estado de desarrollo.

Con la aparición del brote mejoran todos los síntomas; se restablece el apetito, la anemia se atenúa y el estado general se torna cada día más satisfactorio, entrando el enfermo en franca convalescencia. El único elemento que se puede señalar es la acentuación de la hipocromia. 
VERRUGA MULAR DEL CODO
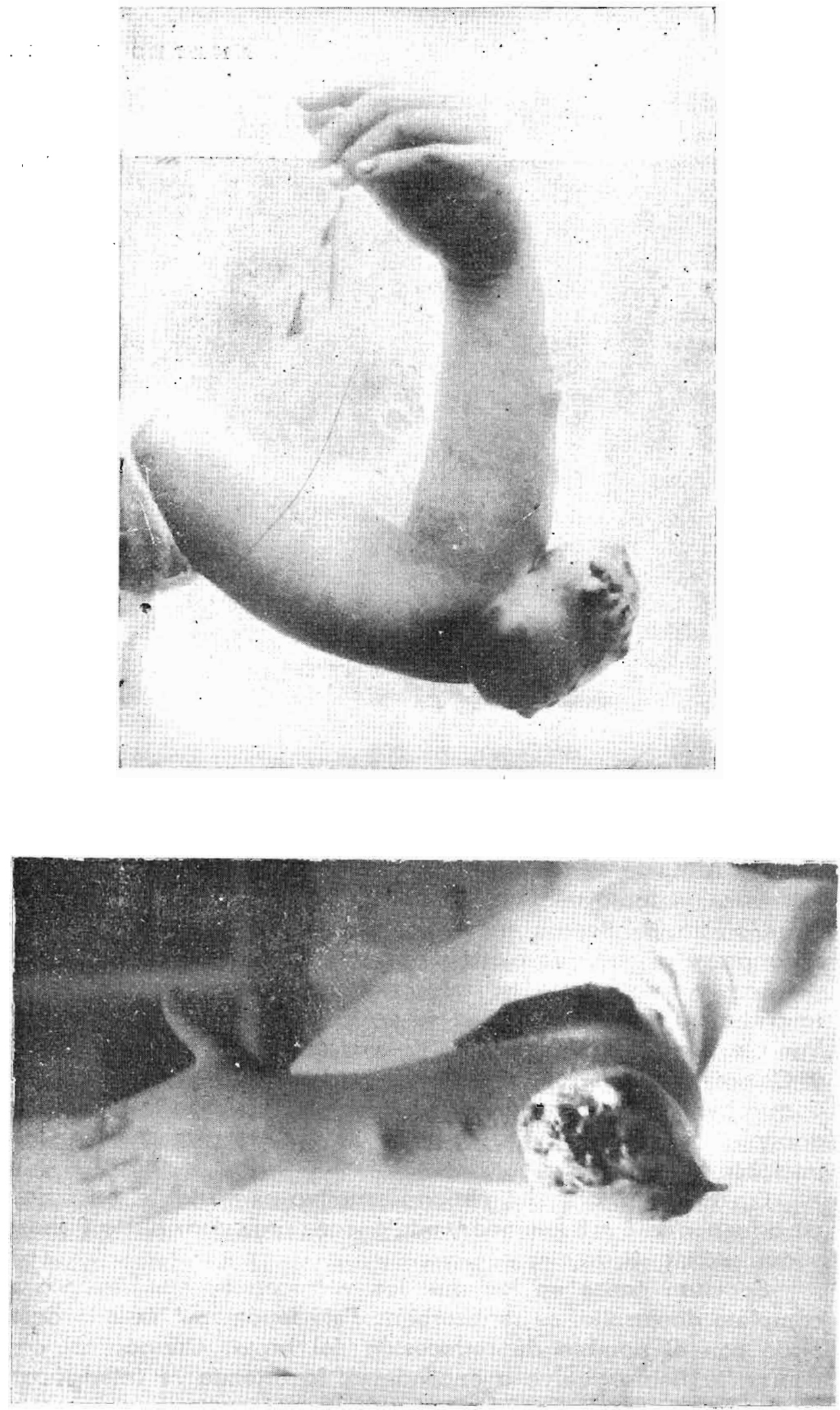

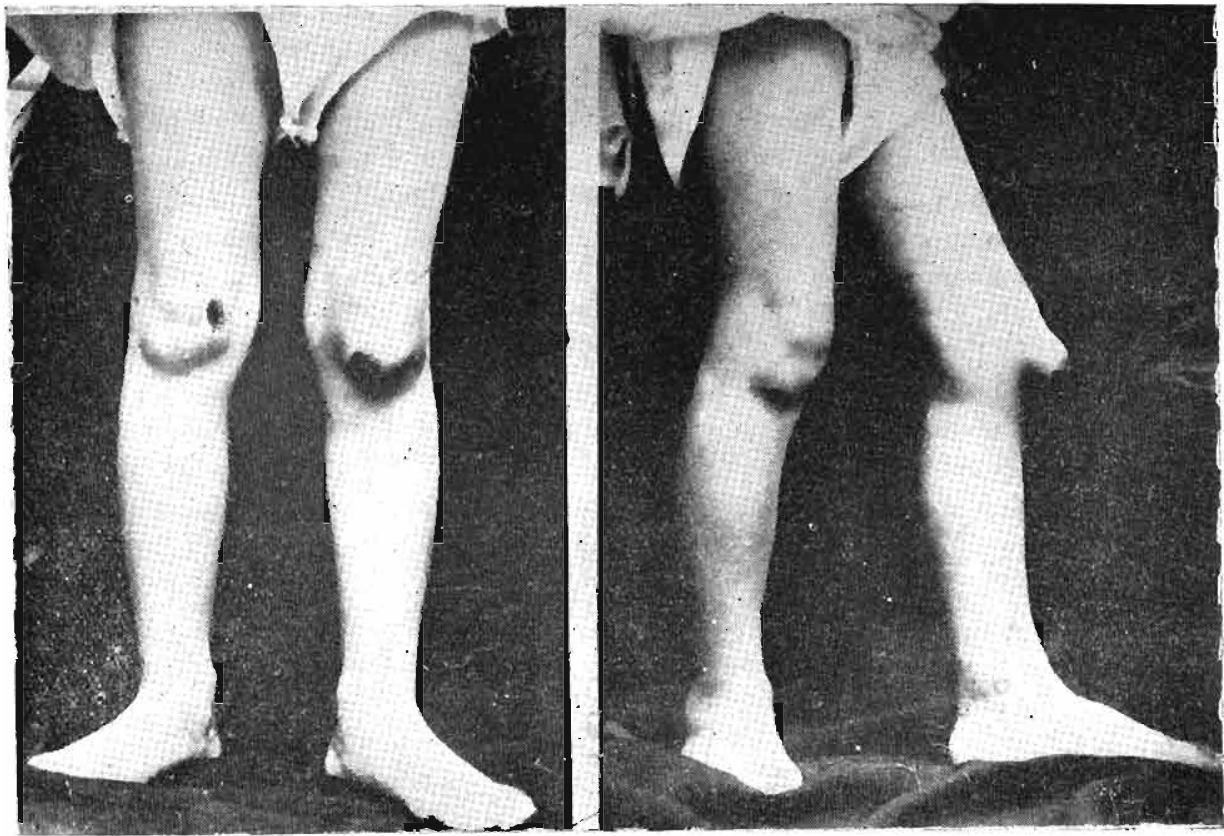

En cuanto a las verrugas mismas, cuando no se erosionan accidentalmente y sangran, llegadas a su madurez, se marchitan, empalidecen, reduciéndose de tamaño para desaparecer sin dejar huella. Algunas se reabsorben; otras se hacen un poco más consistentes, un tanto córneas, al propio tiempo se reducen y caen; otras, en fin, se ulceran, recubriéndose de una costra grisácea que desaparece al cabo de cierto tiempo.

Las verrugas pueden infectarse como consecuencia de la rascadura. Esta eventualidad se ve en los niños en quienes uno que otro verrucoma es asiento de infección local supurada. BifFI y Carbajal ${ }^{73}$ hicieron un estudio bacteriológico de un caso de verrucomas supurados en los que demostraron la existencia de un germen, probablemente del grupo salmonella, asociado a otro microbio fluorescente.

La duración total del período eruptivo es variable, en ningún caso menor de 6 a 8 semanas, pudiéndose prolongar hasta 6 meses y aún más.

Se citan casos en los que los verrucomas, sin llegar a su completo desarrollo, se reabsorben. Este lenómeno ha sido designado con el nombre de retrocesión del brote. Cuando tal cosa ocurre, la fiebre vuelve a encenderse, la anemia se intensifica y 
el enfermo presenta nuevamente manifestaciones análogas a las del período preeruptivo, de mucho mayor gravedad, pudiendo desarrollar el cuadro de la fiebre grave de Carrión, con intensa anemia, muchas veces mortal. Señalamos esta eventualidad en ctención a informaciones proporcionadas por algunos de nuestros Maestros y colegas, sin haber tenido ocasión de verificarlas personalmente en nuestra práctica pediálrica.

Antúnez ${ }^{10}$, Rebagliati ${ }^{18}$, Weiss ${ }^{7 \theta}$ y olros señalan casos de evolución crónica. En los niños, la enfermedad suele ser casi siempre de marcha aguda o subaguda, muy excepcionalmente crónica. Por regla general, un ataque de enfermedad de Carrión les confiere sólida inmunidad para el resto de la vida.

\section{COMPLICACIONES}

En el proceso evolutivo de esta enfermedad, de curso relativamente largo, se presentan diversas complicaciones; unas dependientes de la gravedad que asume la anemia; otras ligadas a los procesos reaccionales del organismo durante el período preeruptivo; otras, en fin, motivadas por el asiento del brote verrucoso o por la evolución especial del verrucoma.

Ocurre, por otra parte, que se presentan complicaciones de. terminadas por asociaciones fatológicas, o mejor dicho, por contaminancias evolutivas con otras entidades que, al entremezclar sus cuadros sintomatológicos, dan matices especiales a la enfermedad de Carrión. Entre estas asociaciones se destacan el paludismo, las infecciones por Salmonellas, las disenterías, el despertar de tuberculosis latentes que entran en actividad al amparo de la anergia que provoca la bartonelosis, $y$, en los niños, no es raro observar la evolución conjunta de la verruga y el sarampión o de aquella y la coqueluche.

En los casos de anemias agudas e intensas las complicaciones obedecen a fenómenos de anoxia anémica y no a perturbaciones de la dinámica circulatoria, por el hecho, demostrado por HuRtado yं colaboradores ${ }^{48}$, de la no existencia de hipovolemia. El deficiente aporte de oxígeno modifica, como es de suponer, el fisiologismo general de la economía. En este sentido, el polimorfísmo sintomático que puede presentarse escapa a toda descripción nosográfica sintética, siendo la clínica la que muestra la individualidad de los 
casos y son los clínicos quienes deben referirlos a su verdadera causa.

En cuanto a los procesos reaccionales del períndo preeruptivo, se observon alteraciones múltiples susceptibles de determinar sindromes clínicos diversos que aparentemente no encuaaran en la sintomatología propia de la enfermedad de Carrión.

Las reacciones degenerativo-exudativas descritas por WeIss ${ }^{15}, 75$ de las que nos ocuparemos más adelante, pueden presentarse a nivel de las serosas como lo han señalado Odrrozol ${ }^{2}$ y ARCE $^{28}$. GONZÁlez OLACHEA ${ }^{B 0}$ describió un interesante caso de proceso pleural con derrame de origen verrucoso; Qumoga y MENA ${ }^{\text {B1 }}$ hace muchos años señalaron reacciones meningoencefólicas; Gó MEz ${ }^{12}$, artritis exudativas, etc.

Esas mismas reacciones suelen generar cuadros clínicos desconcertantes. Tal cosa ocurrió con un enfermo de nuestro servicio que presentó un sindrome de Frugoni, estudiado por nuestro diligente y culto colaborador de la Cátedra, Dr. CACHAY Díaz ${ }^{74}$. Consideramos de interés dar a conocer la historia:

Observación $N^{8}$ 10.-M. R. de 5 años. Historla clínica $N^{9} 783$. Ingresa al servicio en enero de 1941 por presentar una enorme tumoración que llena el lado izquierdo del abdomen. Niña pálida, blen consfituída y lúcida. Llama la atención la asimetría del vientre que se presenta distendido al lado izqulerdo por la presencia de una enorme esplenomegalia. Sangre: 3'100,000 hematíes con 3,000 leucocitos sin alteración de la fórmula.

El estudio del caso llevó a Cachary Díaz al díagnóstíco de sindrome de Frugont o esplenomegalia tromboflebítica. Pensándose operarlo en buenas con. diciones, el $1^{\circ}$ de Abril, sin que nada lo hiclera prever, el bazo comenzó a reducirse espontáneamente, apareciendo al slguiente día un brote de verrugas que en los días sucesivos se transformó en una florlda erupclón. El bazo recobró sus dimensiones normales, saliendo la enferma de alta 4 semanas después del brote.

Dentro de los pocos casos publicados de enfermedad de Carrión en los niños, merece señalarse el de CHREM ${ }^{22}$ quien estudió un enfermo que presentó ictericia obstructiva y sindrome de hipertensión portal, que, para nosotros, obedece al mismo meconismo fisiopatológico que el caso anterior, con diferente localización. Weiss ${ }^{15}$ cita casos clínicos en adultos que semejaron trombosis de las cuatro extremidades, determinados por reacciones exudativoproliferativas a nivel del conjuntivo de todo el paquete vásculo nervioso de las regiones correspondientes. 
En nuestra opinión, todos los casos de neurobartonelosis compilados y descritos por LAstres ${ }^{83}$ no son otra cosa que este tipo de reacciones cuando asientan en distintos lugares del neuroeje o del sistema nervioso periférico.

Como complicación de las verrugas mismas, se observa la supuración. frecuentemente en forma aislada, o raramente generalizada, como el caso publicado por BIfFI y CARBAJAL ${ }^{78}$.

Teniendo el carriónico emborgado su sistema defensivo retículo endotelial, se hace más vulnerable a otras enfermedades. Como el paludismo reina en los mismos lugares donde existe la endemia nacional, la asociación de estas dos enfermedades se ve a menudo, determinando por intrincamiento siftomatológico cuadros febriles de difícil interpretación.

En los niños menores de 2 años, la asociación con enterocolitis disenteriforme es común. Se trata en estos casos, casi siempre, de asociación de la enfermedad de Carrión con Shigellas o Salmonellas. Por fortuna, estas asociaciones que en el adulto son de extraordinaria gravedad, evolucionan en el niño con relativa benignidad.

Tal vez si en esto estriba una de las principales diferencias entre la verruga de los niños y la de los adultos. El dessarrollo simultáneo de bartonelosis con infecciones por gérmenes del grupo tifo-coli fueron conocidas desde los primeros lustros del presente siglo. Ribeyro ${ }^{118}$ que aisló por hemocultivo en gran número de enfermos el bacilo paratífico B. llegó a preparar una vacuna partiendo de la hipótesis de que era este el gérmen que comunicaba la malignidad a la fiebre grave de Carrión.

Recientemente L. A. Aldana ${ }^{84}$, basado en estudios clínicos y bacteriológicos, demuestra en primer término que los similtíficos de la verruga son gérmenes del grupo Salmonella. Cuando se asocia la verruga con salmonellosis en el período preeruptivo el cuadro clínico correspondería a la fiebre de Oroya, fiebre grave de Carrión. Bartonelosis complicada o Salmonellosis carriónica. En casos de no existir esta complicación, si la anemia es intensa, el enfermo desarrollaría la anemia grave de Carrión. Los casos de evolución benigna serían la enfermedad de Carrión, simplemente.

Otra asociación frecuente es con la tuberculosis. En niños que han tenido una primoinfección y en quienes la tuberculosis se enćientra al estado de latencia, puede ella entrar en actividad como consecuencia de la anergia verrucosa. En estas condiciones se 


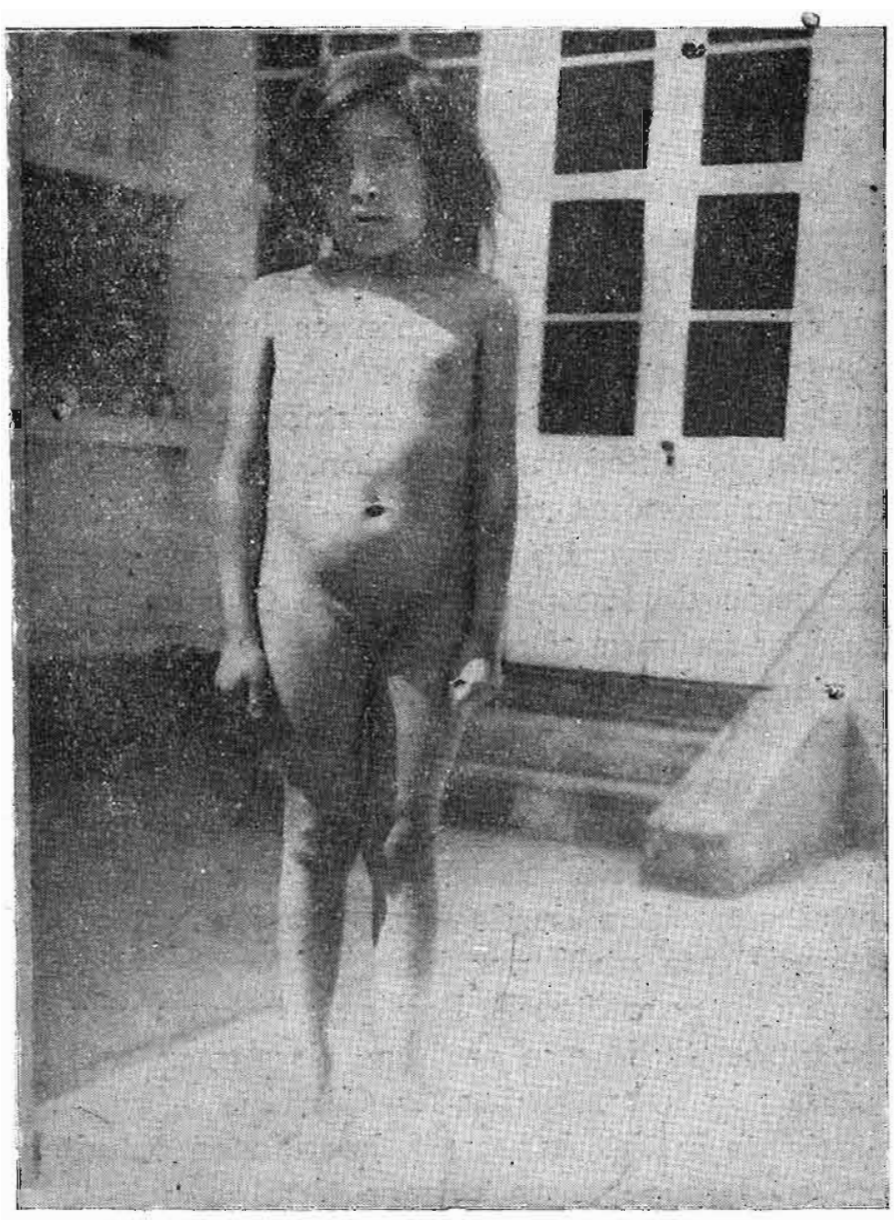

presenta con frecuencia una diseminación hematógena de la tuberculosis, sucumbiendo los enfermos de granulia. Este fenómeno lo hemos observado algunas veces. Como paradigma podemos señalar el siguiente caso:

Observación $N^{\circ} 11 .-H . S$. de 5 años, ingresa a nuestro servicio el año 1944. Historia clínica $N^{\circ}$ 1766. Inicia su enfermedad 8 días antes de hospitalizarse con dolores óseos intensos, náuseas, escalofrío, fiebre vesperal de $39^{\circ}$ que remite en las mañanas, acentuada palidez y anorexia. Procede de una zona verrucosa de Ancash. Al exámen gran adinamia, facies de profundo sufrimiento. La piel y mucosas son tan pálidas que pareden exsangües, taquicardia, micropoliadenia generalizada, hepatomegalia. Análisis de sangre: 825,000 hematirs; 15,800 leucocitos, 2,6 de hemoglobina. $19 \%$ de normoblastos y $1 \%$ de megaloblasios, 


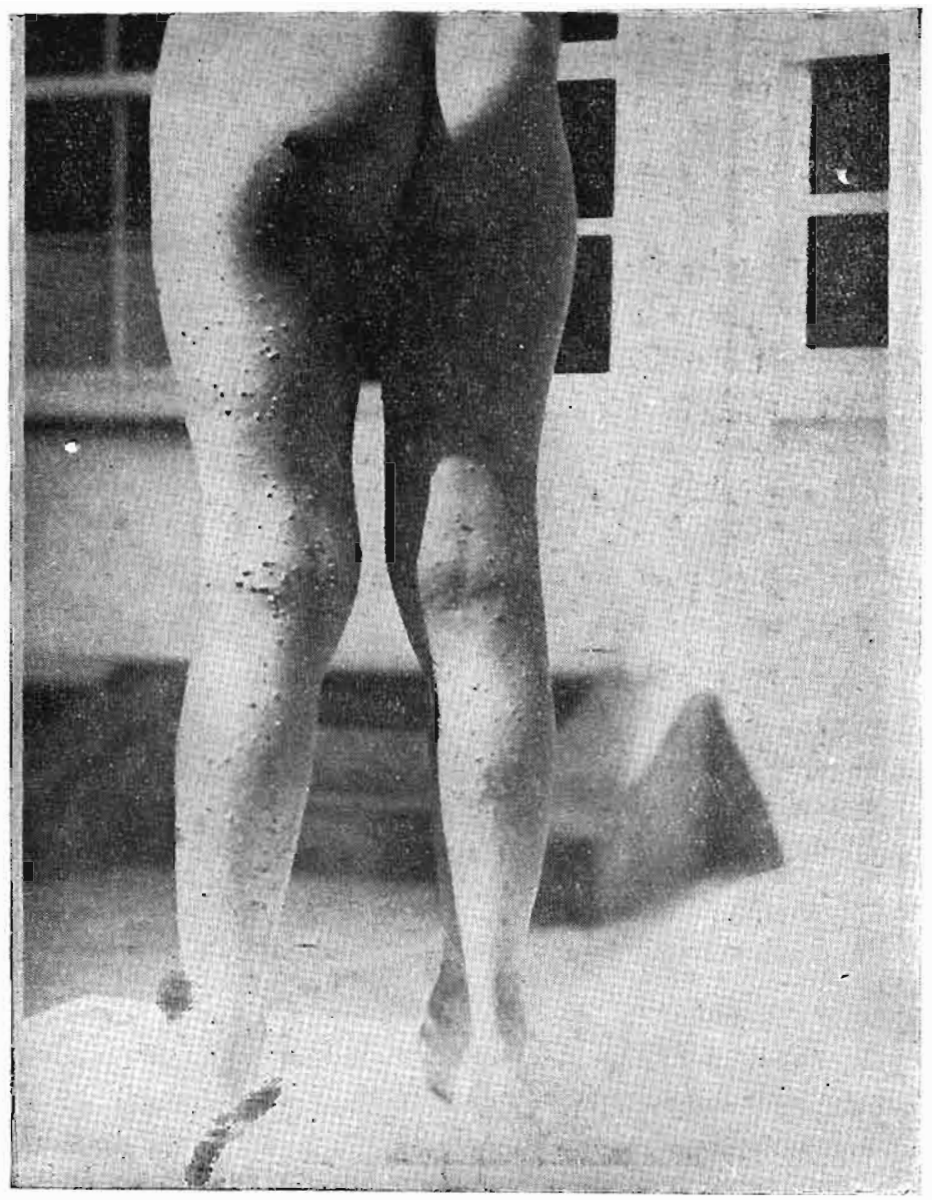




\section{VERRUGÁS MILIARES DE LAS EXTREMIDADES EN LA MISMA ENFERMA}

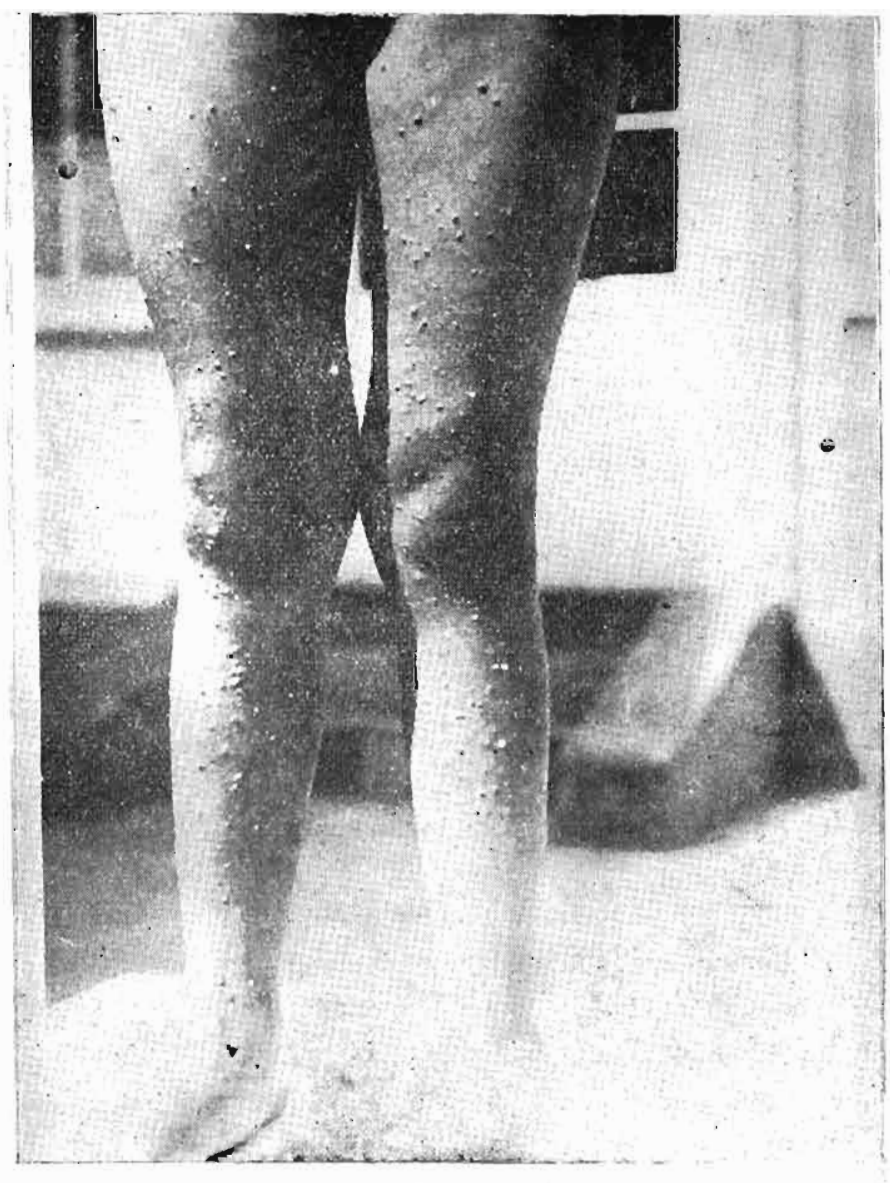


gran cantidad de reticulocitos. Neutrófllos $66 \%$; Linfocitos $33 \%$; Monoctos $1 \%$. Abundantes bartonellas bacilares y cocoldes. Prueba tubercalina negativa.

Después de una ligera mejoría bajo la acción de la penicllina, se agrara al $5^{0}$ día de hospitalización. Aporrecen: edemas palpebrales, esplenomegalia y numerosas petequias, falleciendo 3 días después.

A la necropsia: granulia pulmonar, plelltls, hígado en dégeneración grasosa y derrame pericárdico.

No siempre las cosas tienen una evolución tom grave. En la observación N 9 hemos relatado la historia de una enferma tuberculosa latente que, teniendo un verrucoma laríngeo, la fimatosis no entró en actividad. Debemos dejar establecido el hecho de que esta enferma, durante el período preeruptivo, no presentó los caracteres de la fiebre anemizante grave de Carrión.

También hemos tenido ocasión de observar la asociación de verrugá con sarampión y con coqueluche y las complicaciones broncopulmonares de estas enfermedades. Uno de los casos más interesantes se presentó en el servicio del Dr. Guillermo Filomeno, a quien expresamos nuestro agradecimiento por haber puesto a nuestra disposición la documentación clínica cuyos principales caracteres vamos a describir suscintamente.

Observación N No 12.-El 27 de Agosto de 1948 ingresó al servicio de infectocontagiosos el niño S. C. de 14 meses de edad y 7,500 gramos de peso. Su entermedad se inició 3 meses anles con tos quintosa. En los días que precedieron a su ingreso al servicio tuvo tos y disnea. Al exarnen clínico se comprueba palidez de piel y mucosas, verrugas miliares en la cara y extremidades, estertores diseminados en ambos campos pulmonares, gran hepatomegalia, punta de bazo, mícropoliadenia generalizada.

Análisis de sangre: 2 millones de hematíes; 8.600 leococitos con 2 eosinófllos، 39 neutrófilos, 53 linfocitos y 6 monocitos. Anisocitosis $\theta$ hipocromia. No hay bartonellas al examen directo. Curva vertical de la velocidad de sedimentación que alcanza a $60 \mathrm{~m} / \mathrm{m}$ a la hora. Orina normal. Diagnóstico: Coqueluche y verruga.

Después de experimentar cierla mejoría, a fines de setiembre presenta elevación de temperamento en las tardes. Presencia de hematozoario. Mejora con tratamiento antipalúdico. El brote verrucoso sigue su curso normal. En octubre desarrolla sarampión, empeora su estado nutritivo. El sarampión se complica de bronconeumonía a focos múltiples, y el enfermo fallece.

Este caso, extraordinariamente interesante, pone en evidencia la notable baja de las defensas orgánicas del verrucoso distrófico por hipoalimentación, en quien evolucionaron conjuntamente 
con la enfermedad de Carrión, en el lapso de 2 meses: coqueluche, paludismo, sarampión y bronconeumonía.

No es esta evolución complicada la habitual. La observación Ni 7, lo comprueba elocuentemente: el enfermo A. R. de 7 años que ingresa con un discreto brote verrucoso, contrajo en el servicio sarampión que dió un "coup de fouet" a las verrugas, que crecieron con lozanía.

Es extraordinaria la resistencia de los niños verrucosos para soportar las más diversas complicaciones.

\section{ANATOMIA PATOLOGICA}

La rareza con que fallecen enfermos de verruga sin presentar infecclones sobreagregadas, hace difícil el estudio de las lesiones que caracterizan la enfermedad de Carrión, por considerarse como manifestación anatomopatológicas de ella alteraciones dependientes de las infecciones espúreas.

Por ser la erupción verrucosa lo más característico de la enfermedad, la atención de los patólogos se encausó en los primeros tiempos, hacia la búsqueda de verrucomas en los distintos órganos y tejidos profundos, sin obtener resultados satisfactorios; habiendo sido necesario electuar gran número de investigaciones y estudios experimentales, para poder definir las características anatómicas e histológicas de la enfermedad de Carrión.

Para poder hacer una exposición ordenada y metódica de la patología seguiremos el mismo orden que nos hemos trazado en la descripción clínica, señalando las principales lesiones que se encuentran durante los períodos evolutivos de la enfermedad: incubación, invasión o período preeruptivo, brote y regresión.

En lo que al período de invasión se refiere, ya hemos dicho que clínicamente es asintomático. Anatómicamente tampoco se han descubierto alteraciones que indiquen con certeza la puerta de entrada.

Del gran número de estudios experimentales que se han llevado a cabo se desprende que en la verruga no hay chancro de inoculación. En este sentido, la auloexperiencia de KUCZYNSK $\Gamma^{86}$ y el estudio anatómico de las lesiones efectuado por MACKEHENIE ${ }^{87}$, ofrecen singular importancia. 
Kuczynski se inoculó repetidas veces en los antebrazos troumatizados previamente, con cultivos virulentos de bartonellas obtenidos de enfermos que habícn sucumbido de fiebre grave de Carrión. En el punto de la inoculación, al igual que en la experiencia de Carrión, lo único que pudo advertirse fué las huellas de las inoculaciones, y subjetivamente sensación de escosor. MacKEHENIE ${ }^{87}$, al ocuparse de la evolución de los verrucomas, deja constancia de que después de la latencia (incubación) pudo demostrar propagación por vía linfática desde el granuloma aparecido en uno de los puntos de inoculación hasta los grupos ganglionares correspondientes. Este mismo fenómeno que había tenido ocasión de comprobar en estudios experimentales anteriores llevados a cabo con Jiménez Franco , le permitió concluir que la Bartonella incita la proliferación del conjuntivo ambiente hasta alcanzar los ganglios homolaterales. En todo el trayecto de las vías linfáticas correspondientes se pueden apreciar cordones tumefactos que siguen esas mismas vías. La aparición ulterior de verrugas en regiones anatómicas muy alejadas de los sitios de inoculación, observadas en Kuczynski, le hacen colegir una diseminación hemática ulterior.

La difunsión linfática de la infección concuerda con el hecho clínico de observarse infartos ganglionares en los enfermos durante el período preeruptivo, sea que desarrollen o no el cuadro anemizante agudo febril de las formas malignas de la enfermedad de Carrión.

En el período de invasión o preeruptivo, tiene lugar la colonización de la bartonella en las células endoteliales. Desde el punto de vista anatómico, el hallazgo característico de la enfermedad de Carrión, como dice Weinman ${ }^{42}$, es la presencia de células endoteliales en cuyo citoplasma prolifera exuberantemente la Bartonella. Estos elementos fueron puestos en evidencia por Strong y colaboradores" 40 . Aldana ${ }^{20}$, sugiere que se les llame "células de Strong", las que se encuentran extraordinariamente difundidas durante el período preeruptivo, descubriéndose en los ganglios linfáticos, hígado, médula ósea, bazo, riñón, cópsulas suprarenales, páncreas, testículo, corazón, pulmones, hipófisis, vellosidades intestinales, etc., es decir, prácticamente, difundidas en el organismo entero.

Se trata de células endoteliales dentro de cuyo citoplasma se encuentra una cantidad enorme de elementos pequeñísimos de 
aspecto bisomático, coloreables con los derivados del Romanowsky que no son otra cosa que Bártonellas. En algunos casos, como dice STrong ${ }^{40}$ las células están extraordinariamente dllatadas por los gémenes que obstruyen la luz vascular.

El hallazgo de los gérmenes dentro de las células endoteliales es difícil, por sus exiguas dimensiones, sus peculiares afintdades tintoriales y por su breve trónsito en estos elementos. Con tales dificultades tropezó ALDANA ${ }^{47}$, quien estuvo a punto de pensar que Strong no había encontrado verdederos gérmenes sino granulaclones debidas $a$ "artificios de preparaclón o degeneraciones celulares". El "hallozgo de estas células endoteliales parasitadas tienen el mismo valor que la comprobación de los verrucomas o de las Bartonellas en la sangre.

En lo que se refiere a las alteraciones post-mortem que se presentan en los órgonos y tejidos de la economía, se han llevado a cabo importantes estudios.

Destacan en primer término los trabajos de Hercelies ${ }^{90}$, quien dió a conocer las alteraciones que había comprobado en los diversos órganos. Extractamos los aspectos más importantes que ha señalado dicho investigador.

El bazo se presenta aumentado de volumen, congestionado, con focos hemorrágicos, infartos y signos evidentes de hiperfunción, tanto en su actividad destructiva cuanto en la productiva de elementos sanguíneos, notándose hiperplasia folicular y metaplasia eritropoyética.

Considera a los ganglios linfáticos como los principales órganos en los que se hace la fijación de los gérmenes productores de la enfermedad, señalando su hipertrofia habitual y lesiones de adenitis descamativa, además de infartos y hemorragias.

Describe en la médula ósea dos clases de lesiones: proliferativas, como respuesta a la anemia, y degenerativas, por trastornos vasculares. CARVALLO ${ }^{91}$ en un estudio sobre el mismo asunto que puede considerarse como clásico, señaló la transformación de la médula amarilla en roja, con hiperplasia de todos los elementos a predominio de normo y megaloblastos $y$ sus antecesores los megalocitos, y en la serie blanca intensa reacción neutrófila con tendencia mielocítica. Además, proliferación histiocitaria y megacariocítica y acentuada actividad fagocitaria, lo que a la luz de 
los nuevos conocimientos denota hiperactividad retículo-endotelial de los órganos hematopoyéticos.

En el hícado, llama la atención el predominio de alteraciones vasales y sanguíneas: dilataciones venosas, éstasis, infartos y hemorragias. Hace también Hercelles una descripción con gran riqueza de detalles de las alteraciones en los distintos aparatos, órganos y tejidos.

Estas importantes comunicaciones constituyeron en su época los estudios anatómicos más completos de la enfermedad de Carrión. Muchos de los puntos tratados inducen al estudioso en el momento actual a serias meditaciones.

WeIss ${ }^{75}$, valiéndose de biopsias cutáneas practicadas a enfermos durante el período preeruptivo, cuando ha concluído la profunda anemia y han desaparecido las bartonellas de la sangre, o sea, clínicamente, el momento biológico comprendido entre el término del periodo preeruptivo y el comienzo del brote; describe una serie de modificaciones estructurales de inmenso interés teórico y práctico que demuestran los esfuerzos que realiza el organismo para librar la batalla final de la infección, que culminan con la erupción verrucosa.

A esta etapa, que Weiss llama período histioide sin erupción macroscópica, corresponde una serie de alteraciones que esquemáticamente consisten en neoformaciones capilares, destrucción de endotelios vasales, formación de trombos y hemorragias intersticiales, etc. Un fenómeno importante que ocurre en los precapilares es la proliferación adventicial, entrevista por Hercelles ${ }^{90}$ y designada por MACKEHENIE" con el nombre de "reacción adventicial de Weiss". Este fenómeno se opera de preferencia en territorios perivasculares lo que, al determinar irregularidades de calibre, entorpece la circulación.

Las importantes comprobaciones de $\operatorname{STRONG}^{40}$ y WEISS ${ }^{75}$ demuestran en forma incontrovertible que el ataque y la defensa en la enfermedad de Carrión se opera en el sistema retículo endotelial.

Los estudios de ALDANA ${ }^{89}$ ratifican y complementan los de su Maestro Hercelles, poniendo de relieve el difundido parasitismo de la Bartonella en los órganos y los tejidos, con la circunstancia de que los gérmenes no atacan las. células parenquimatosas, sino el conjuntivo que las envuelve y los vasos que las irrigan. 

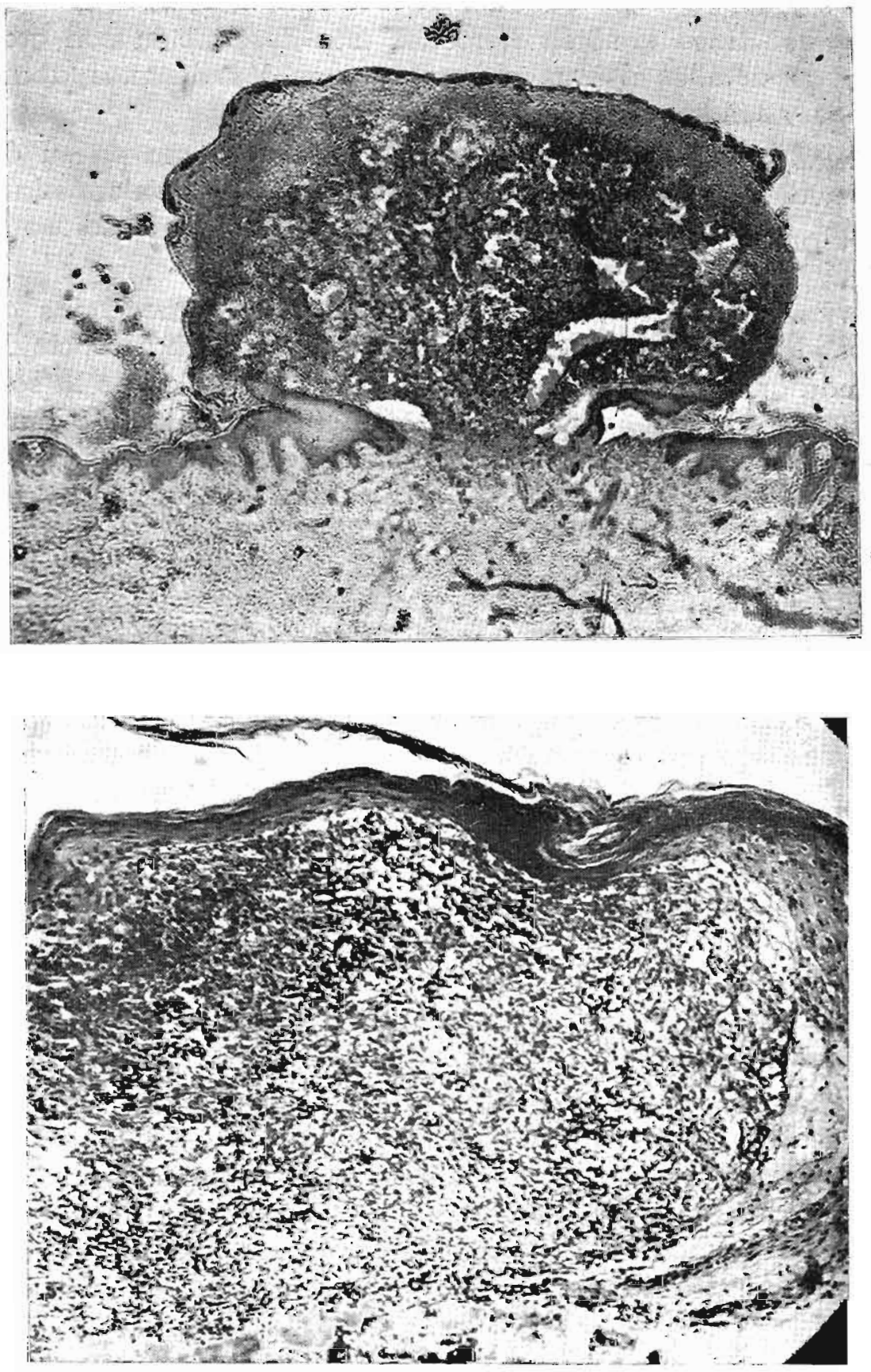


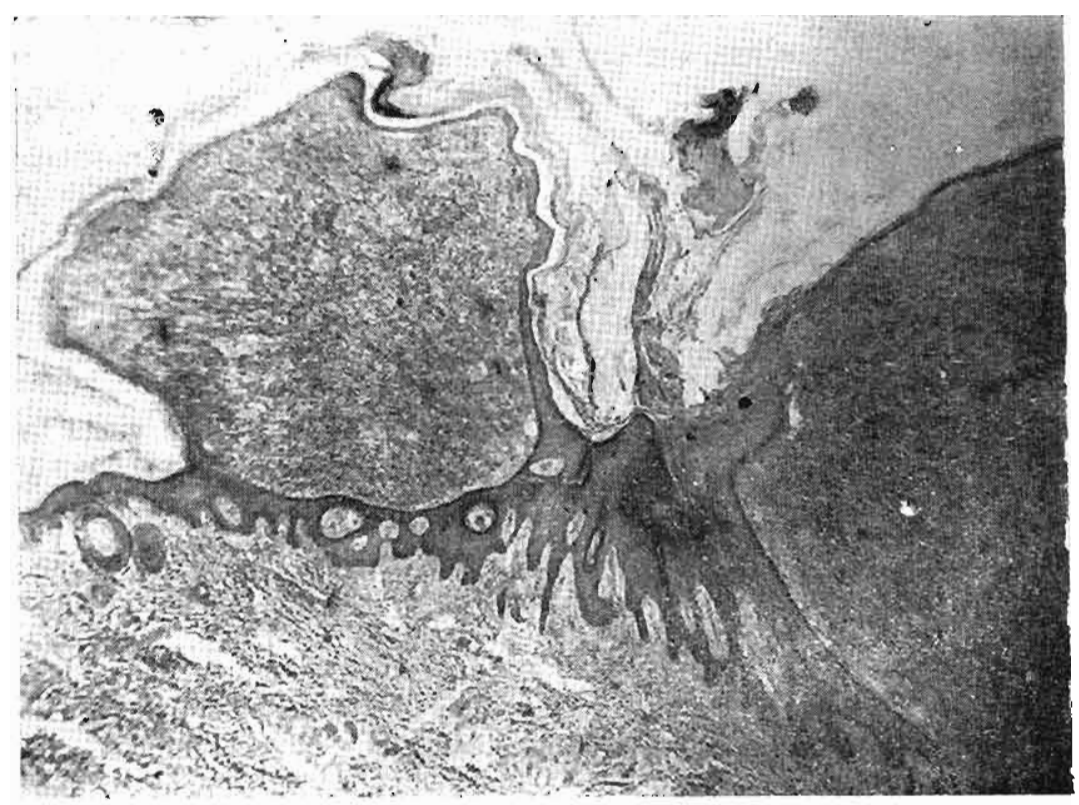

Con amplio criterio interpretativo, MACKEHENIE ${ }^{92}$ asigna como sede de la lucha entre la noxa y el organismo los tejidos de origen meserquimal. Gracias a las potencialidades múltiples de este sistema, es que polariza sus actividades, ora captando, fijando y destruyendo las bartonellas y los hematíes parasitados por ellas, ora recobrando aptitudes hematoyéticas ancestrales produciendo hemohistioblastos, ora encamina su acción vasogénica creando angioblastos. El mesénquima interviene así, de principio a fin de la enfermedad, destruvendo los gérmenes, compensando la anemia y engendrando los granulomas.

Convencido del importante rol que desempeña el ganglio linfático, Hercelies ${ }^{93}$ practica biopsias ganglionares, comprobando que al lado, de la gran cantidad de bartonellas existentes en los senos linfáticos y dentro de las células endoteliales, existen alteraciones del órgano mismo que recaen en el folículo y en los senos linfáticos. En el primero, descubren hemorragias centrofoliculares determinadas por trombosis, lo que altera la textura reticular del órgano. En cuanto a los senos linfáticos, es allí donde encuentran la mayor cantidad de bartonellas, a tal punto que considera este fenómeno de tal fidelidad que recomienda las biopsias ganglio- 
nares como elemento de valor diagnóstico comparable sólo al hallazgo de bartonellas en la sangre periférica.

Tanto en los ganglios linfáticos como en todos bs tejidos de la economía, el sistema retículo endotelial prolifera mostrando su actividad por signos de eritrofagia, metaplasia eritroide, neoformación capilar y presencia de depósitos de hemosiderina. En algunas zonas se puede apreciar obstrucciones vasculares e infartos subsecuentes.

Reacciones semejantes se comprueban en el bazo cuya armazón conjuntiva denota proliferación del retículoendotelio, con existencia de los mismos fenómenos de eritrofagia, trombosis venosas, infartós y depósitos de siderina.

Ya hemos dicho que uno de los órganos que presenta mayor parasitismo es el riñón, en el que, según ALDANA 47 , los gérmenes pueden ponerse en evidencia en el tubo urinífero, mas no en el glomérulo. En el parénquima renal, las alteraciones son discretas: ligera infiltración grasosa de las células del tubo. En el tejido intersticial no difieren de las que se presentan en los demás órganos.

El hígado siempre se afecta. Habitualmente está hipertrofiado, pudiendo señalarse marcada proliferación de las células de Kupfer que contienen en su interior hematíes, leucocitos y bartonellas. Hay adiposis de grado variable en la célula hepática, dilatación de los canalículos biliares y zonas de necrosis alrededor de las venas centrolobulillares.

Mucho menos marcadas son las lesiones de las vísceras torácicas. Pinkerton y Weinman ${ }^{94}$ señalan la existencia de petequias en el músculo cardíaco. STRoNg y colaboradores ${ }^{40}$ encontraron estas mismas alteraciones a nivel del pulmón y la pleura.

En los centros nerviosos, Mackehenie y Alzamora ${ }^{95}$ describen lesiones caracterizadas por proliferación adventicial que asientan a nivel de los vasos y el tejido glial.

En el período eruptivo, la lesión característica es la verruga misma. Estas eflorescencias que en la actualidad son bien conocidas desde el punto de vista estructural, llamaron siempre la atención de los investigadores. VÉLEZ ${ }^{96}$ fué el que hizo la primera descripción de ellas, señalando que se forman a expensas del 
cuerpo papilar y que sólo pueden asentar a nivel de la piel. Más tarde, Hercelles ${ }^{87}$, hace una descripción del nódulo el que cree debido a una proliferación periarterítica a cuyo alrededor se establece un lóbulo. EscomeL ${ }^{98}$, considera que se forman trombosis microbianas que dan origen a la proliferación periarterítica de "células verrucosas" nacidas a expensas del conjuntivo, lo que determina la neoformación verrucosa. Sucesivamente, aparecen nuevos estudios de Mayer, Rocha Lima y Werner ${ }^{54}$, de STrong ${ }^{40}$, de Ribeyro, Arce y Mackehenie ${ }^{55}$, etc.

De toda esta serie de trabajos se desprende que el verrucoma es un granuloma circunscrito muy vascular que asienta en zonas edematizadas del tejido conjuntivo, determinado per la bartonella baciliformis, cuya presencia es constante. Está constiłuído por acentuada proliferación angioblástica, con la consiguiente formación de neovasos. En algunas zonas se notom elementos histiocitarios e infiltraciones leucocitarias.

A medida que envejecen, toman un aspecto angiomatoso; aparecen fibroblastos, la irrigación sanguínea disminuye, el verrucoma palidece, se originan trombosis vasculares, luego se infiltra de células eosinófilas, sus elementos constitutivos entran en degeneración, la verruga disminuye de dimensiones, terminando por desaparecer, si antes no se ha reabsorbido sin dejar huella alguna.

Tales son, sintéticamente expuestos, los principales hechos anatomopatológicos adquiridos. De ellos se desprende que la enfermedad de Carrión tiene como asiento el sistema retículo endotelial.

\section{INVESTIGACIONES BIOQUYMICAS}

Los primeros estudios biocquímicos de la verruga fueron efectuados por García Godos ${ }^{29}$ quien, al estudiar la orina de los carriónicos pudo comprobar la existencia de marcado descenso de la relación azotúrica, lo que implica alteraciones funcionales hepáticas.

Monge ${ }^{100}$ llamó la atención acerca de la naturaleza hemolítica de la ictericia que presentan algunos enfermos de verruga. GuzMÁN BARRón ${ }^{101}$, por medio de la reacción de van der Bergh prac- 
ticada en verrucosos con o sin ictericia, pudo verificar que la bilirrubina indirecta era fuertemente positiva en los casos de anemia intensa, señalando también la positividad de la diarzoreacción de Ehrlich y de la de Moritz Weiss, afirmando igualmente la existencia de urobilina urinaria. Estos estudlos confirmaron la existencia de un componente hemolítico en la anemia de la fiebre grave de Carrión, tal como lo había señalado Monge algunos años antes. Iguales resultados obtuvieron HURT ADO y colaboradores $^{48}$. La gran destrucción globular, por una parte, y la disminución de la excreción de bilirrubina por la célula hepática, por otra, no sólo demuestran la naturaleza hemolítica de la anemia sino también perturbaciones en el funcionalismo hepático.

Conocida la relación que existe entre el descenso de la cantidad de colesterina sanguínea y las anemias y el rol que desempeña esa sustancia en los fenómenos de inmunidad y alergia, GUZMÁn BARRón ${ }^{102}$ llevó a cabo investigaciones sobre el comportamiento de la colesterina en la bartonelosis, encontrando hipocolesterinemia en los casos de intensa desglobulizaclón, sin que exista paralelismo entre el grado de anemia y la proporción de colesterina. En el período eruptivo, en cambio, el tenor de colesterina aumenta, sobre todo en los enfermos que han presentado intensa anemia.

La cantidad de ácidos aminados en la sangre ha sido determinada por Pons y URTEAGA ${ }^{103}$ quienes comprobaron en un enfermo con grave anemia carriónica, aumento de la aminoacidemia, en concordancia con los resultados obtenidos experimentalmente en el perro. Esta alteración denota también profundas perturbaciones en la actividad hepática.

Entre las constantes biológicas orgónicas, la proporción de las albúminas plasmáticas y la relación serina-globulina, se modifican al estado patológico. Merino ${ }^{104}$ puso en evidencia un descenso constante del cuociente serina-globulina. En el período preeruptivo existe hipoproteinemia total moderada, con hiposerinemia marcada hecho que 'explican' la frecuencia de los edemas, 'mientras que en el período eruptivo hay tendencia a la hiperproteinemia, con hiposerinemia moderada y manifiesta hiperglobulinemia.

De significativo valor para la interipertación de la anemia son los caracteres de la secreción gástrica, que ha sido estudiada. por GuZMÁn BARRón ${ }^{105}$ y por HuRtado y colaboradores ${ }^{48}$. Estos 
estudios colnciden en que existe hipofunción secretoria gástrica, caracterizada por hipoclorhidrla, anaclorhidria y en algunos casos se puede observar aquilia verdadera.

En un reducido número de nuestros enfermos, hemos comprobado que las pruebas de floculación de insuftciencia hepática: Hanger, timol y oro cololdal, dan resultado positivo.

DeLGado Febres ${ }^{106}$ al efectuar investigaciones sobre metabolismo pigmentario, ha podido comprobar un considerable aumento del urobilinógeno fecal, superior en más de 20 veces a la cifra normal, en enfermos durante el período preeruptivo con anemia grave y presencia de bartonellas en los hematíes. En todos ellos las pruebas hepáticas de floculación dieron resultados positivos, análogos a los que nosotros mismos hemos comprobado. Durante el período eruptivo, la excreción de urobilinógeno fecal urinario, permanece dentro de límites normales lo que demuestra, en forma directa, que en la génesis de la anemia de la enfermedad de Carrión existe un severo componente hemolítico.

\section{PA TOGENIA.}

En lo que se refiere a la patogenia de la enfermedad de Carrión, Espina ${ }^{32}$ fué el primero en considerar la unidad etiológica de la fiebre grave de Oroya y la verruga peruana, opinión que compartían distinguidos clínicos de fines del siglo pasado: Salazar, Alarco, Flores y otros. Fué Avendaño ${ }^{107}$, el año 1885, quien dió la primera interpretación patogénica después de la trágica experiencia de Carrión, al decir que la fiebre de Oroya no era otra cosa que el período anemizante febril, que en los casos de alta gravedad precede a la erupción verrucosa. Esta tesis reinó entre los médicos peruanos durante muchos años.

En 1927, WeIss ${ }^{75}$ dió a conocer una concepción patogénica que, a despecho de las críticas y de los años transcurridos, constituye la doctrina verrucogénica que cuenta con el mayor número de adeptos en el país.

Estableció denifitivamente, sobre bases conatómicas y clínicas, que la verruga es una enfermedad retículoendotelial cuyo desarrollo se opera en dos fases: una hemática, con presencia de bartonellas en la sangre, y la otra histloide, fruto de la reacción 
del retículoendotelio frente al agente cousal, que termina con la formación de los granulomas verrucosos.

El fin de la fase hemática se anuncia por la crisis hemática de MONGE ${ }^{60}$ la destrucción hemática se detiene; las bartonellas desaparecen de la sangre al examen directo, y aparece la fórmula leucocitaria con monocitosis y eosinofilia, fenómenos que corresponden a la fórmula de inmunidad de Schilling ${ }^{103}$, la que cronológicamente fué descrita por Monge en la verruga, algunos años antes de que el sabio hematólogo alemán diera a conocer sus importontes investigaciones.

En la fase histioide se presentan dos posibilidades: presencia - ausencia del brote macroscópico. La primera comprende a la erupción verrucosa misma; la segunda corresponde a la serie de fenómenos clínicos que Odriozol ${ }^{2}$ desginó con el nombre de período intercalar.

Inspirándose en analogías evolutivas y clínicas con el reumatismo, considera Weiss que en la erupción verrucosa entran también en juego dos elementos descritos por KLINGE ${ }^{109}$ : 19 un estado exudativo-degenerativo, con caracteres semejantes, más no idénticos, a los que preceden a la formación de los nódulos de Aschoff (edema local, infiltración, focos hemorrágicos y lesiones degenerativas o destructivas); $y, 2^{\circ}$ un proceso proliferativo que se desarrolla a expensas de los angioblastos. Mientras en la enfermedad reumatismal predomina el factor exudativo degeneratvo, slendo discretas las manifestaciones proliferativas, en la enfermedad de Carrión ocurre el fenómeno contrario: las manifestaclones exudativas son discretas, y exuberantes los fenómenos proliferativos que pueden llegar en ocasiones a producir inmensas verrugas mulares.

Basado MACKeHENie ${ }^{110}$, 111, 112, en el asiento mesenquimal de la enfermedad, en el aspecto ricketziforme de la bartonella y en algunos caracteres clínicos semejontes existentes entre la verruga y los tifus, sugiere que la enfermedad de Carrión debe salir del aislamiento nosológico en el que se le ha querido situar, para ser incorporada a la gran familia de los tifus. Paz Soldám basado en estos puntos de vista, definió la verruga como un "tifus anemizante y botonoso". Esta tesis, no obstante ser muy sugestiva, no es seguida por la mayoría de clínícos y patólogos del país. 
Para Alzamora ${ }^{114}$ la fiebre de Oroya sería la bartonelosis aguda, caracterizada por abundante pululación del microbio en la sangre. El esfuerzo reaccional del organismo obligaría al gérmen a radicarse en los elementos endoteliales, perdiendo la cptitud para determinar procesos de marcha aguda, pero sí capaces de originar una enfermedad benigna cuyo corolario sería la erupción verrucosa. Entre estos dos tipos reaccionales extremos existiría una gama de formas intermediarias.

En una serie de trabajos realizados por AldanA ${ }^{89}$ basados en estudios bacteriológicos y anatomoclínicos, interpreta la génesis de la enfermedad de Carrión en forma completamente diferente a todas las anteriores. Para él, la Bartonella sería un microbio mutante, susceptible de actuar frente al organismo humano bajo tres aspectos diferentes, cada uno de los cuales estaría dotado de actividad patógena distinta.

Una de sus formas, es la bacilar, la otra, ricketzial, tomando la tercera los caracteres de virus. La primera se observa como parásito transitorio y epiglobular en los casos de anemia grave de Carrión; la segunda, ricketziforme, es la que se observa en el período que precede al parasitismo hemático, cuando el gérmen se muestra fundamentalmente endoteliófilo; la bartonella virus correspondería a las inclusiones clamidozoicas descritas por $\mathrm{MA}$ YER, ROCHA LIMa Y WeRneR ${ }^{54}$ en la verruga misma, encontrándose como tal durante el período eruptivo de la enfermedad.

La bartonella asumiría todas estas mutaciones, de carácter reversible, como consecuencia de las interacciones entre el germen infectonte y el organismo que se defiende de la noxa tratando de destruirla. Pero en los medios de cultivo, la bartonella siempre tendría sus típicos caracteres baciliforme o cocoide.

Nosotros, situámdose en el terreno clínico y apoyados en las investigaciones bacteriológicas, anatomopatológicas, bioquímicas y fisiopałológicas precedentemente expuestas, consideramos la enfermedad de Carrión como una entidad cíclica, de marcha subaguda generalmente, con tendencia a la cronicidad algunas veces, que evoluciona en cuatro períodos perfectamente definidos: Incubación, que se extiende desde el momento de la picadura del insecto transmisor hasta la aparición de los primeros síntomas clínicos; invasión o preeruptiva, cuyos límites se extienden desde el fin de la incubación, hasta la aparición de las primeras manifestaciones eruptivas; 
erupción, que comprende el brote característico, hasta el comlenzo de la regresión, que constituye el cuarto y último período de la enfermedad. Como en todo cuadro nosográfico, las fronteras de cada uno de los períodos evolutivos no slempre son fáciles de precisar en la verruga.

El periodo de incubación es silencioso y se caracteriza por la difusión primaria del gérmen en el organlsmo, la que se opera por vía linfática, como lo admiten ReBagliati ${ }^{18}$, MACKEHENIE $^{87}$ y muchos otros, basándose en las experiencias de KuczYNSKI ${ }^{86}$. La tendencia endoteliotropa de las bartonellas y su avidez de oxígeno las hacen invadir los endotelios capilares y linfáticos donde anldan proliferando rápida $\theta$ intensamente.

El segundo período corresponde a la fase hemática de Welss; en él, las células endoteliales distendidas al máximo por la exuberante proliferación del microbio, estallarian dentro de la luz de los vasos, diseminando la infección por vía hemalógena. En este período, el sistema retículo endotelíal, aún no ha logrado establecer sus defensas en forma adecuada para destruir el gérmen. Muy verosímilmente, la difusión hemática no es una verdadera septicemia sino, más bien, una serie de descargas bartonelémicas.

En estas condiciones pueden ocurrir dos fenómenos: o las descargas bartonelémicas son masivas debido a una gran proliferación microbiana, dando origen a la fiebre anemizante grave de Carrión; o las bacteriemias son paucimicroblanas, en cuyo caso la anemia es discreta, el estado general de los enfermos satísfactorio y el mecanismo inmunobiológico sigue su curso normal hacia el brote o erupción, como es la regla en los niños.

Los hematíes cargados de bartonellas son captados por el sistema retículo endotelial. A esta hematofagla inicial sigue un proceso de digestión o lisis de los hematies parasitados, lo que determina la anemia por hematofagia y hemolisis, tanto más intensa cuanto mayor es el parasitismo hemático y la hematofagia consiguiente.

En el determinismo de cada uno de los dos aspectos clínicos, juegan importante papel el estado constitucional del enfermo, les virulencia del microbio y la coexistencia de enfermedades infecciosas latentes que se manifiestan en forma activa gracias a la disminución de la resistencia orgónica, producida por la propia bartonelosis. 
El tercer período, o eruptivo, está constituido por el brote verrucoso, exponente de inmunidad y término del ciclo activo de la lucha entresel microbio y el organismo. El período de regresión - seca no es otra cosa que la desaparición de los granulomas del organismo, y la restitución completa al estado de salud.

No quiere decir esto que todas las bartonellas desaparezcan completamente al término del ciclo nosológico de la enfermedad. El organismo puede continuar albergóndolas durante un tiempo indeterminado, fenómeno biológico bien conocido en gran número de enfermedades. El establecimiento de la inmunidad solo significa una potencialidad adquirida por el ser vivo, que lo hace refractario a las agresiones de un microbio determinado, pudiendo este último continuar como huésped inócuo para el organismo inmune, el que se transforma así en portador de gérmenes y fuente de diseminación de la enfermedad. A esta ley de patología general, también está sometida la entermedad de Carrión.

Vamos a detenemos muy brevemente a analizar el mecanismo fisiopatológico de algunos de los síntcmas de la Verruga, a la luz de las recientes adquisiciones.

Ya hemos señalado el mecanismo de la anemia. Los edemas obedecen a hiposerinemia que trae como consecuencia la ruptura del equilibrio onkótico. La hiperglobulinemia, traduce una hiperactividad retículo endotelial. Así se desprende de los trabajos de Whipple ${ }^{114}$. Es probable que sea la fracción gamaglobulina la que debe estar fuertemente aumentada, por el rol que juega en los mecanismos inmunitarios. Desgraciadamente, no se han efectuado estudios electroforéticos que pudieran haber aclarado el punto. La misma significación que la hiperglobulinemia nos parece que tiene la hipercolesterinemia del estado preeruptivo.

Nos inclinamos a pensar que la fiebre se debe a dos factores: la infección propia de la bartonelosis y la liberación por hemolisis de gran cantidad de núcleos pirrólicos de acción piretógena.

Los estudios bioquímicos y los hallazgos anatomopatológicos descritos a nivel del hígado demuestran evidente perturbación orgónica y funcional de la glándula hepática. Precisamente, la elevada proporclón de globulinas plasmáticas, con descenso de la seroalbúmina, indica incapacidad de la cédula hepática para efectuar la síntesis de la serina. Igual significación de insuficiencia 
funcional hepática tiene la hiperbilirrubinemia y la disminución del coeficiente azotúrico.

En lo que respecta a los demás síntomas: gastreintestinales, nerviosos, respiratorios, etc. obedecen a la infección y muchos de ellos a la anoxia anémica, demostradas ambas ampliamente en las numerosas investigaciones realizadas.

Ciertas manifestaciones desconcertantes, tales como el síndrome de Frugoni y la ictericia obstructiva, para solo señalar las que han sido descritas en los niños y a las que nos hemos referido, tienen por substratum anatómico reacciones proliferativas que, sin llegar a la producción del granuloma específico, obedecen a proliferaciones adventiciales que, pueden constituir obstáculos mecánicos y dificultades de la hemodinámica capaces de provocar los más variados síndromes clínicos.

Las múltiples manifestaciones nerviosas que, con el nombre de neurobartonelosis, han sido descritas en gran número de casos de verruga tienen idéntico mecanismo patogénico.

\section{DIAGNOSTICO}

En el período eruptivo no existe problema diagnóstico en la enfermedad de Carrión: el enfermo la exhibe. Tampnco presenta dificultades en el período preeruptivo cuando hay intenas omemia, pues el análisis de songre revela al existencia de Bartonellas.

Los tropiezos se encuentran cuando los enfermos llegan en apirexia o subfebriles, pálidos, con trastornos gastrointestinales, dolores y desinejoramiento del estado general. En tales condiciones el clínico se siente perplejo, pues la enfermedad de Carrión puede confundirse con cualquier infección de marcha tórpida, según el predominio de alguno de los síntomas iniciales.

No existe ningún síntoma clínico en el período preeruptivo que sirva de elemento de certeza. La procedencia del enfermo es tam solo un dato presuntivo. Las características hematológicas tampoco definen la enfermedad.

Las momifestaciones dolorosas carecen de especificidad. En el lactante se confunden fácilmente con las de la sífilis congénita, sobre todo si se aprecia esplenomegalia, anemia $\theta$ infartos ganglionares, debiendo recurrirse a la serología y a la radiología para 
disipar las dudas. En los niños mayores inducen a error cuando asumen tipo reumatismal.

La pluralidad sintomática ocasionada por lo irregular del asiento proliferativo adventicial, a lo que hemos hecho referencia precedentemente, da origen a los más variados cuadros clínicos, siendo la sagacidad del práctico la que puede referirla a su verdadera cousa. La aparictón del brote disipa todas las dudas.

Sería necesario recorrer gran parte de la patología para poder mostrar todos los errores susceptibles de cometerse, pues la enfermedad de Carrión puede pasar confundida con un sinnúmero de dolencias.

El cirterio realmente seguro para poder afirmar la naturaleza de la enfermedad es la comprobación de su agente causal: la Bartonella baciliformis. Esta solo se encuentra, lo repetimos, al examen directo cuando la anemia es muy intensa. Indirectamente, puede comprobarse su existencia por medio del hemocultivo. Fué TORREAlba ${ }^{115}$ quien por primera vez dió las pautas a seguirse con tal fin, señalando que los resultados positivos alcanzan al $85 \%$ de los casos en los que no se encuentra la Bartonella al examen directo de la sangre.

Las investigaciones de Hurtado y colaboradores ${ }^{23}$ en Tornamesa han puesto de manifiesto la existencia de portadores crónicos y de infectados aparentemente sanos en la proporción de $13 \%$ de los individuos estudiados en aquella zona verrucosa. Estos hallazgos no restan importancia al hemocultivo como medio seguro de diagnóstico en los casos dudosos, toda vez que en quienes se efectúa el hemocultivo es en sujetos con síntomas clínicos de enfermedad de Carrión. El resultado positivo en tales condiciones significaría enfermedad en plena evolución.

La biopsia ganglionar, recomendada por Hercelles como medio de diagnóstico precoz, sería un procedimiento complementario y muy seguro en caso de abrigarse dudas, puesto que no solo permite comprobar la presencia de bartonelas, sino también poner en evidencia lesiones anatomopatológicas de gran valor. 


\section{PRONOSTICO}

Evolucionando la enfermedad de Carrión en los niños, en forma rápida hacia la erupción, no siendo la anemia grave tan frecuente como en el adulto, y siendo las complicaciones mucho mejor toleradas, el pronóstico de la verruga es benigno en la infancia.

Durante la diseminación hemática en el período preeruptivo, es cuando la enfermedad ofrece mayor gravedad. Sin embargo, aún es mucho mejor soportada por los niños con cifras hemáticas de 1 millón de eritrocitos que por los adultos.

La razón fundamental del mejor pronóstico de la verruga en la infancia obedece a que los niños poseen un vigoroso sistema retículo endotelial que los libera con cierta facilidad del parasitismo hemático, y las pérdidas sanguíneas se compensan con gran celeridad gracias a su activo sistema hematopoyético.

En lo que a complicacicnes o asociaciones con otras enfermedades se refiere, la mortalidad en los niños es mucho menor que en las demás etapas de la vida. Mientras que en el adulto Hurtado y colaboradores ${ }^{48}$, señalan el $62 \%$, cifra que para Alzamora ${ }^{113}$ es de $88 \%$ y que JimÉnez Franco ${ }^{116}$ hace elevar a $96 \%$, en los niños solo alcanza al $45 \%$ según nuestras estadísticas.

No hemos tenido ocasión de observar la retrocesión del brote. Parece que ciertas enfermedades, en vez de hacer retrogradar la erupción la estimulan. Este fenómeno fué patente en la observación No 7 en la que la aparición de sarampión durante el período eruptivo de la verruga, lejos de provocar la retrocesión, avivó el brote verrucoso.

No es de extrañar el diferente pronóstico que tiene la enfermedad de Carrión en función de la edad. Ya hemos dicho, y éste es nuestro convencimiento, que, siendo la verruga una enfermedad de la infoncia, cuando se presenta en la edad adulta es de mucho mayor gravedad, fenómeno fácil de advertir en casi todas las enfermedades infecciosas y eruptivas. La verruga no puede hacer excepción a esta regla.

El pronóstico varía según la procedencia de los individuos. Los nativos de las zonas verrucosas son más resistentes que los forasteros. Este fenómeno es aplicable tanto al niño cuanto al adulto.

La raza autóctona soporta mejor la enfermedad de Carrión que el mestizo, y este mejor que el blanco. Por consecuencia, al es- 
tablecer el pronóstico, deben tomarse en cuenta estos factores cuya interpretación no puede ser otra que la adquisición de cierto grado de inmunidad, mayor resistencia, o mejor aptitud defensiva racial adquirida a través del tiempo.

El sexo también influye en el pronóstico. En el hombre la enfermedad es más severa que en la mujer, y la mortalidad mucho mayor.

La coexistencia de la verruga con tuberculosis activa o evolutiva, sobre todo cuando ambas coinciden en la diseminación hemática, es de alta gravedad. En tales casos, la muerte suele ocurrir casi siempre por granulia pulmonar, o generalizada, o por meningitis tuberculosa, fenómenos que hemos podido comprobar numerosas veces en la mesa de autopsias.

En el período eruptivo, el pronóstico siempre es bueno en los niños. La enfermedad es más molestosa que grave, pudiendo provocar pérdidas sanguíneas de consideración pero que no comprometen la vida de los enfermos.

La introducción de los antibióticos, como veremos más adelante, ha hecho cambiar en parte el criterio pronóstico de la enfermedad de Carrión.

TRATAMIENTO

Hasta los primeros lustros del siglo actual, solamente se empleaban medicamentos sintomáticos en el tratamiento de la verruga, sin obtener otro resultado que demostrar su ineficacia. Huérfanos de remedios efectivos, los clínicos antiguos confiaban más en la "vix medicatrix natura" que en los agentes terapéuticos que esgrimian contra la enfermedad de Carrión, empleándolos, sin duda, con la fundada esperanza de que la psicoterapia farmacológica, comunicara alientos a los enfermos en los momentos de mayor grorvedad.

Se emplearon después agentes de acción fisiopatológica, los que, al producir cierta tregua en la marcha, muchas veces inexorable de la enfermedad, gozan aún en la actualidad de indicaciones cabales en determinados casos.

Cuando la anemia del período preeruptivo asume gravedad, las transfusiones sanguíneas, sigulendo las directivas trazadas por 
Muñoz Barata117, ham mostrado real eficacia. En los niños, esta terapéutica ha proporcionado notables resultados.

Pero cún cuando el proceso anémico se supera, los pacientes, sobre todo adultos, sucumben con frecuencia, víctlmas de enfermedades espúreas que, al complicar la verruga en el momento de mayor peligro, le hacen asumir gran malignidad. A este tho clínico se refería $A_{R C E^{26}}$ al hablar de verruga maligna como una forma "hipertóxica, violenta y casi slempré fatal de la enfermedad de Carrión".

La índole de este trabajo sólo nos permite dar a conocer muy a la ligera almunos enscryos terapéuticos, basados en consideraciones etiopatogénicas. Al observar Ribeyrolls en un gran número de casos la asociación de la verruga con infección a paratífico $B$, recomendó el uso de vacuna ontiparatífica a fin de despertar la inmunidad contra estos gérmenes de asociación secundaria.

Los sorprendentes resultados alcanzados con la quimioterapia en el tratamiento de ciertas enfermedades provocadas por protozoarios, indujeron a ARCE ${ }^{119}$ a ensayar el salvarsan, partiendo de la hipótesis que la verruga debía ser producida por algún protozoario. Los resultados se tradujeron en una mejoría del cuadro anémico, sin ejercer acción alguna sobre el presunto protozocrio.

La observación clínica, al poner en evidencia que la aparición del brote significa el período terminal del ciclo de la Bartonella en el organismo, con el consiguiente establecimiento de Ia inmunidad, hizo concebir a algunos clínicos la idea de emplear revulsivos cutóneos que estimularan la erupción: fricciones de la piel, con trementina, sinapismos, etc. Bernales ${ }^{120}$ recomendó la terapéutica citotofiláctica por medio de inyecciones endovenosas de cloruro de magnesio. Todos estos métodos tuvieron que ser abandonados por no dar ningún resultado.

Los ensayos de Roca y Boloña 121 con el empleo de glicerina, por felices que haýan sido algunos de sus resultados, sólo pueden tomarse como elementos coadyuvantes en el tratamiento, y carentes de especificidad.

Un producto quimioterápico estiboarsenical preparado en Leverkusen con el nombre de Bayer 386, o S. D. T., de acción efectiva en las bartonelosis animales, fué ensayado por ManriquE ${ }^{122}$. Un 
apreciable historial clínico demostró resultados alentadores, los que no fueron ton satisfactorios en manos de NIETO ${ }^{123 .}$

La intraducción de los antibióticos en la terapéutica movió a los investigadores peruamos a aplicarlos en el tratamiento del mal autóctono, con resultados muy alentadores. Fué en nuestro servicio que se hizo el primer ensayo en el país, por medio de penicilina, por nuestros asistentes Drs. Cachay Díaz y VÍllehez ${ }^{124}$, desgraciadamente en un enfermo que ingresó "in extremis". Por la misma fecha, Merino125 fué afortunado, en su primer ensaryo; habiendo sido desde entonces que comenzó a difundirse esta terapéutica en la enfermedad de Carrión.

Aldana y Tisnado 128 investigaron la acción dé la penicilina en cultivos de Bartonellas demostrando que poseía notable acción bacteriostática y antibiótica. A determinada concentración impide el desarrollo de la Bartonella, y en dosis menores afecta la morfología del gérmen.

Gran número de clínicos hicieron conocer los resultados que obtuvieron con la nueva droga. En nuestro servicio del Hospital del Niño, pudimos comprobar que la penicilina a la dosis diaria de 200,000 unidades, produce una rápida desaparición de la Bartonella de la sangre periférica y una mejoría efectiva del cuadro hemático. La acción del antibiótico en el periodo eruptivo no es tan eficaz. Sobre estos puntos estan de acuerdo todos los que han empleado penicilina.

Siendo la verruga una enfermedad cíclica, sostenemos que si la penicilina fuera un agente específico efectivo, debería detener la marcha de todo el proceso en cualquiera de sus períodos, Ia que no ha podido demostrarse toda vez que en gran número de observaciones se ha podido comprobar que la desaparición de la Bartonella de la sangre y la mejoría del enfermo, no implica la supresión del periodo eruptivo.

También se ha usado la estreptomicina, cuya eficacta, según nuestra experiencia personal es más espectacular aún que la de la penicilina. Hemos observado casos de fiebre grave de Carrión con un parasitismo hemático de $90 \%$ reducirse al $15 \%$ en las primeras 24 horas del empleo de estreptomicina, desapareciendo por completo 48 horas más tarde al mismo tiempo que la anemia mejora y el enfermo se recupera. La dosis empleada ha sido de 1 gr. diario. En lo que se refiere a la erupción, los resultados son análogos a los que se advierten con la penicllina. 
Battistini More, MUÑoz P. y Tisnado 127 han comprobado que la estreptomicina está dotada también de propiedades bacteriostáticas y antibióticas sobre los cultivos de Bartonellas.

Un reciente trabajo de Aldana, Zubiate y Contreras ${ }^{128}$ da a conocer la observación de un enfermo que, tratado con dosis insuficientes de estreptomicina, creó una resistencia del gérmen al antibiótico que demandó el empleo de penicilina para obtener la curactón.

Sintetizando nuestra experiencia terapéutica con estos aritibióticos, nos permitimos recomendar el empleo de ellos en dosis altas, precozmente administradas y usadas en forma prolongada.

También hemos usado la cloromicetina, gracias a las facilldades y consejos que nos brindó el Dr. Payne mientras estuvo de tránsito entre nosotros. Desgraciadamente, sólo la pudimos emplear en enfermos en períado eruptivo. Este antibiótico sintético lo hemos ensayado en dos formas de aplicación: supositorios de 400 miligramos tres veces al día, y cápsulas de 250 miligramos a la dosis diaria de 50 miligramos por kilo de peso. En el reducido número de enfermos en que hemos experimentado, observamos que la vía rectal es menos efectiva que la oral.

Bajo la acción de la cloromicetina las verrugas palidecen, se marchitan y tienen tendencia a la desecación. A las 24 horas de administrar el antibiótico ya se nota el cambio de coloración. Cuando se suspende el tratamiento, vuelven a ingurgitarse y revivir. Uno de nuestros enfermos a quien bajo la acción de la cloromicetina oral, le desapareció su brote comenzante, a los tres días de interrupción del tratamiento presentó un nuevo brote que no pudimos combatir por hebérsenos terminado la droga. Consideramos que sería conveniente forzar la dosis los primeros días y luego montenerla por una semana en la cantidad de 50 miligramos por kilo. Para nosotros, se trata de un valioso agente terapéutico que debe ser ensayado en el período preeruptivo.

Creemos que debe darse preferencia en el tratamiento a la estreptomicina y a la cloromicetina porque estos antiblóticos, a la vez que actúan sobre la Bartonella, son de notoria eficacia sobre los gérmenes del grupo Salmonella, los que, en el adulto sobre todo, asociando sus éfectos con los de la enfermedad de Carrión, comunican a esta inusitada gravedad. 
La aplicáción de antibióticos en el tratamiento de la verruga significa el más efectivo progreso terapéutico alcanzado hasta Ia fecha.

PROFILAXIA

Desde el punto de vista profiláctico, en el proceso de la verrucogénesis deben tomarse en consideración tres factores: la fuente o reservorio del virus, el agente transmisor y el individuo sano. Por otra parte, las zonas endémicas, desde el punto de vista de la distribución geográfica de la enfermedad, son hien conocidas, lo que limita o circunscribe las medidas sanitarias a tomarse.

Los tres factores primordiales a los que acabamos de hacer alusión constituyen los eslabones de una cadena que, al romperse uno solo de ellos, se logra evitar la difusión de la enfermedad.

Está plenamente demostrado que el ser humono es el reservorio del virus, pudiendo albergarlo en las siguientes condiciones:

19 Los individuos clínicamente sanos, que nunca han dado manifestaciones de enfermedad de Carrión y que sin embargo están infectados;

$2^{\circ}$ Los sujetos portadores de gérmenes que, habiendo tenido la enfermedad, han curado, pero continúan teniendo bartonellas en su organismo, en forma semejante a lo que ocurre en otras enfermedades infecciosas; y.

39 Los enfermos en proceso evolutivo.

El agente transmisor, como ya lo hemos dicho, es un insecto alado, hematófago, cuya hembra pica de noche y que encontrómdose muy difundido en las zonas endémicas, es conocido con el nombre de "titira" o Phlebotomus verrucarum.

El tercer elmento es el hombre sano. Aún no se ha podido prejarar vacunas específicas que produzcan inmunidad activa. Por consiguiente, no existiendo ningún procedimiento preservativo que haga refractario al hombre sano contra la infección bartonelósica, la profilaxia debe dirigirse sobre los otros elementos que intervienen en la génesis de la enfermedad.

La esterilización bacteriológica de las fuentes de infección constituídas por los seres humanos, portadores crónicos, infectados o enfermos, es cuestión, prácticamente, irrealizable en la actualidad. 
Es muy difícil determinar la cantidad de individuos infectados en las zonas endémicas y aún en el supuesto de que tal cosa pudiera realizarse, el aislamiento de ellos sería una abra casl imposible de llevar a cabo.

Sólo resta como elemento para poder realizar una campaña activa de profilaxia la lucha contra el insecto transmisor. Campañas sanitarias de esta índole se han llevado a cabo con óptimos resultados en otras enfermedades igualmente transmisibles por picadura de insectos. Baste recordar la erradicación de la fiebre amarilla en Río de Janeiro y en Panamá, las campañas antimaláricas y antiexantemáticas, etc. Los poderosos insecticidas actuales, y entre ellos D. D. T., son muy activos contra el Phlebotomus, según lo han podido demostrar Hertig ${ }^{129}$ y Gorbitz ${ }^{22}$.

La lucha contra el Phlebotomus Verrucarum presenta ciertas dificultades, por no conocerse con exactitud el clclo vital natural del insecto. No obstante ésto, se deberá procurar su aniquilamiento al estado adulto con una campaña continuada de dedetización en las zonas endémicas, la que deberá ser centrífuga, teniendo en cuenta la ampliación de esas zonas verrucosas en función de los regímenes pluviales.

Mientras la lucha contra el vector no se realice en tal forma, son de recomender ciertas precauciones de aplicación inmediata, de acuerdo con los conocimientos epidemiológicos. El individuo sano debe eludir la permanencia en las zonas verrucosas después de las 5 de la tarde, y si no le fuera posible hacerlo por circunstancias especiales, usará de repelentes, cuya acción es breve y transitoria.

Los mosquiteros y telas metálicas, no son muy recomendables. Las pequeñas dimensiones del Phlebotomus demandarían usarlos de mallas muy tupidas que en la práctica resultan incómodos.

El conocimiento que se tiene hoy día de la enfermedad de Carrión, en lo que se refiere a su etiología y epidemiología como a su tratamiento y profilaxia, han llegado a tal grado de progreso que podemos abrigar la esperanza de que en un tlempo relativamente breve, se podrá hacer desaparecer la Verruga de la faz de la tierra.

Cuando los médicos peruanos haryamos conseguido tal cosa, entonces habremos cumplido el compromiso contraído con Carrión quien, la víspera de su muerte, recomendó a un estudiante de 
primer año de medicina que perseverara en la obra que estaba segando su vida, con las siguientes solemnes palabras: "oún no he muerto, amigo mío, ahora les toca a Uds. terminar la obra ya comenzada, siguiendo el camino que les he trazado".

\section{BIBLIOGRAFIA}

1.-Zárate Agustín de: Historia del Perú. Madrid 1862:

2. - Odriozor E Ennesto: La Maladie de Carrion ou la Verruga Peruvienne. Georges Carré et C. Naud. Ed. Paris 1898.

3.-Patrón Pablo: La verruga de los conquístadores del Perú. La Crónica Médica. No 65. Lima 1889:

4.-Monge Carlos: La entermedad y la muerle de Carrión. Anales de la Fac. de Med. $\mathrm{N}^{0}$ extraordinarlo. Lima 1925.

5.-Rebagliati Raúl: Enfermedad de Carrión. Verruga peruana. Flebre de Oroya. Dalos históricos. Actualidad Médica Peruana. No 1. Lima 1935.

6. - Fataciolr D.: Apuntes para la historia y la endemoepidemiología de ld enfermedad de Catrión. An. Hosp. $\mathrm{N}^{0} 7,8$ y 9. Lima 1929.

7.-Vhagas fano A.: La Verruga peruana a través de la historia. Tesis de la Fac. de Medicina. Lima 1938.

8. - Valdizh Hermilio: Apuntes para una bibliografía perluoma de la enfermedad de Carrón. An. de la Fac. Med. No extra. Lima 1925.

9.-Comby Jules: Traité des Maladies de l'enlance. $7 \mathrm{me}$ ed. Vigot freres Ed. Paris 1928.

10. - Antúnez DÁmaso: Distribución geográfica de la verruga en el departamento de Ancash y algunas particularidades clínicas de la entermentad. Actas y trabajos del V Congreso Médico Latinoamericano (VI Panamericano). Tomo V. Lima 1914.

11.-Vhldez C: Una nueva zona verrucosa en el departamento de Cajamarca. Actas y lrabajos del V Congreso Médico Latinoamericano (VI Panamericano). Tomo V. Lima 1914.

12. -Gómez MÁximo: Epidiemiología de la enfermedad de Carrión en las provincias de Yauyos y Cañele. Ac. y trab. del V Cong. Med. Lalinoam. VI Panamericano. Lima 1914.

13. - Pérez Velízquez N: Contribuclón al estudio de la geogralía médica del Dept. de Cajamarca. Act. y trab. del V Congr. Med. Latinoam. Lima 1914.

14.- Lorente Sebastian y Flores Córoova Raúl.: Estudios sobro geograíla médica y patología del Perú. Lima 1915.

15.-Weiss PEDro: Contribuclón al estudio de la verruga peruana o enfermedad de Catrión. Rev. Med. Latinoamericana. Ne 214. Buenos Alres 1933.

16.-Rebagliatt Rafli Geografía de la Verruga peruana. An. de la Fac. de Med. Lima 1937.

17.-Rebaglatr R: Sisiemalización geográlica de la Verruga peruana. An. de Acad. de Clencias Exact. Físic. y Nat. Lima 1939. 
18.-Rebagliati R: Verruga peruana. (Enfermedad de Carrión). Ed. Torres Aguirre. Lima 1940.

19. -Giles Alberto: La enfermedad de Carrión en la Hoya del Huallaga. La Reforma Médiça. Lima 1947.

20. - Patiño Camargo: la barlonelosis en Colombia. La Relorma Médica $N^{9} 313$ Y 314. Lima 1939.

21.-Hertig Marshall: Conferencia en el inst. Nacional de Higiene. Bol. Inf. de la Asoc. Med. Per. Daniel A. Carrión. Lima 1938.

22.-Gorbitz Gmo.: Bases del control sobre la verruga. Edit. P. T. C. M. Lima 1947.

23. - Hurtado A. Merino C. y Pons J: Informe del Dept. de mediclna experimental del Inst. Nac. de Higiene. Lima.

24. -Mackehenie D.: Plantas resorvorios de virus. Contribución de la fitopatogénesis peruana. La Reforma Médica No i62. Lima 1933.

25.-Mackehenie D.: Algunas disquisiciones sobre la Bartonella do la Jatropha Macrantha. La Reforma Médica N 207. Lima 1937.

26. - Arce Julián: Contribución al estudio de la patología nactonal. La enfermedad de Carrión o Verruga peruana. Biblioteca de los An. de la Fac. de Med. Lima. 1920.

27. - Towsend J: La fitira es transmisora de la verruga. La Crónica Médica No 588. Lima 1913.

28.-Battistini T.: Esludios sobre la Verruga peruana. La acclón Médica. Lima 1929.

29.-Noguchi hideyo, Shanon C. Tilden E. B. y Tyler J. R.: The Insects vectors of Carrio's disease. The Journal of Exp. Med. 1929.

30.-Valdizḱn Hermilio: Apuntes para la historia de la verruga peruana. An. Fac. de Med. N' extra. Lima 1925.

31. -Tschudi: Citado por Odriozola.

32.-Espinel: Cilado por Odriozola y Arce.

33.-Izquierdo: Citado por Odriozola y Comby.

34. -Flores Ricardo L.: Citado por Odriozola.

35. - Barton Alberto: El germen patógeno de la entermedad de Carrón. La Crónica Médica $\mathrm{N}^{0} 301$ y 302. Lima 1901.

36.-Biffi U., Tamayo M. y Gastiaburú J. C.: Apuntes sobro la bacterlología de la enfermedad de Carrión. La Crónica Médica N 406 y 407. Lima 1905.

37. -Barton Alberto: Cuerpos endoglobulares en la sangre verrucosa. Gaceta de los hospitaies $N^{\circ} 46$. Lima 1905.

38.-Barton Aiberto: Descripción de elementos endoglobulates hallados en los entermos de llebre verrucosa. La Crónica Médica No 481. Lima 1909.

39.-Strong R., Tyzzer E., Brues C ., Sellards A. W., y Gastiaburú J.: Informo preliminar de la primera expedición a Sudamerica del Dept. de mellicina tropical de la Universidad de Harvard. Act. y trab. del V Congr. Med. Latínoam. VI Panamer. Vol. V. Lima 1914.

40. -Strong R., Tyzzer, Brues, Sellards y Gastiaburu: Report of tirst expedition to Soulh América 1913. Combridge 1915.

41.-Gastiaburú J. y Rebagliati R.: Sobro la hemalología y la ellología de la enfermedad de Carrión. La Crónica Médica N ${ }^{\circ} 501$. Lima 1912. 
42. -Weinman Dand: Infectious anemias due to Bartonella and related red cell parasites. Transactions of the Amerlcan Phllosophical Soclety Philadelphla 1944.

43.-Mackehenie D. y Battistini T.: Contribución al estudio de la verruga peruana. Arch. de la Asoc. Per. para el prog. de la Clencia. Lima 1922.

44.-Mackehenie D. y Weiss P.: Contribución al estudio de la verruga peruana. Gaceta médica peruana $\mathrm{N}^{\circ}$ 18. Lima 1926.

45. - Hercelles Oswaldo: El gérmen de la verruga pervana. Anales de la Fac. de Medicina. Lima 1926.

46. - Mackemenie Daniel: Patología de la enfermedad de Carrtón. Academía Nacional de Medicina. Lima 1932.

47. - Aldana Luis: Bacteriología de la entermedad de Carrión. Tesis de la Fac. de Medicina. Lima 1929.

48. - Hurtado A. Pons J. y Merino C.: La anemia de la entermedad de Carrión (Verruga peruana). An. Fac. de Ciencias Médicas. Lima 1938.

49. - Alzamora Victor: Enfermedad de Carrlóni ensayo etiopatogénico. An. Fac. Cienc. Med. Lima 1940.

50.-Battistini T.: Contribución al estudio de la Verruga peruana. An. Fac. de Med. $N^{0}$ extra. Lima 1925.

51.-Hercelies O.: Nota preliminar sobre cultivo del germen de la verruga peruana. Comunicación presentada a la Facultad de Medicina. Lima 1925.

52. - Battistini T.: Contribuctón al estudio de la verruga peruana. Cultivo de la Barlonella baciliformis. A.n. Fac. de Med. No 4, 5 y 6 . Lima 1927.

53.-JaDassonn y SeIfFert: Citados por Rebagliati,

54. - Mayer Martin, Rocha Lina $\mathrm{H}$. y Werner H.: Untersuchungen über Verruga peruviana. Münchener Med. Osch. 1913.

55.-Ribeyro Ramón, Arce Julián y Mackehenie Daniel: Estudio experimental de la enfermedad de Carrión. La Crónica Médica Ne 596. Lima 1913.

56. -Noguchi H.: La eliología de la Verruga peruana y de la thebre de Oroya. La Crónica Médica. Lima 1929.

57. - Noguchi H., Shannon C., Tilden E. B. y Tyler J. R.: Nuevos estudios sobre la enfermedad de Carrión. La Acción Médica No 121. Lima 1930.

58.-Noguchi H.: Verruga in the dog and the donkey. The Journ. of Exp. Med. 1929.

59.-MAYer M. y KiKuTh W.: Zur Aetiologie und Einhell der Vertuga peruviana. Arb. n. Gebiet d. Auslandskunde. Vol. 26.

60.-Arana Sialer: Estadística hospitalaria. Lima.

61.-Salazar Tomas: Historia de las verrugas. Gaceta Médica de Lima $N^{0} 38$ y 39. 1858.

62.-Medina C., Mestanza E., Arce J., Alcedan M., Miranda J., Montero M.: La Verruga peruana y Daniel A. Carrión. Lima 1886.

63.-Malpartida A.: Embarazo y enfermedad de Cartón. La Reforma Médíca No 272 y 273 . Lima 1937.

64.-Mimeela P. S.: La curva térmica en la enlermedad de Carrión. La Crónlea Médica No 213. Lima 1887.

65. -Tamayo Manuel O.: Hematología de la entermedad de Carrión. La Crónica Médica No 235. Lima 1898. 
66.-Hercelles O.: Injerto de paludismo con la enfermedad de Carrión. La Crónica Médica $\mathrm{N}^{\circ} 236$. Lima 1898.

67.-Birfi Ugo y Gastiaburú Julio C.: Sobre las hemoaglutininas de la sangte humana y la hematología de la entermedad de Carrión. La Crónica Médica $N^{8} 344,345$ y 346 . Lima 1903.

68.-Gastiaburú J. C.: Estudios sobre la enfermedad de Camión. La Crónlca Médica No 572. Lima 1912.

69.-Monge Carlos: Algunos puntos de la hematología de la entermedad do Carrión. La Crónica Médica N $\mathrm{N}^{9} 525$ y 526. Lima 1812.

70.-Monge Carlos: El mielocito basófilo homogéneo en la entormedad do Carrión. La Crónica Médica No 572. Llma 1913.

71. - Arce Julikin: La anemía de la flebre grave de Carribn. La Crónica Médica No 597. Lima 1913.

72.-Weiss Pedro: Una comunicación sobre Verruga peruana. Gaceta Médica Peruana No 17. Lima 1925.

73. - Monge Carlos y Weiss P.: A propos de l'hematologio de la Maladio de Carrion ou Verrue peruvienne. Rev. Sudamericaine de Medecine et d Chirurgie $\mathrm{N}^{\circ}$ 6. Paris 1930.

74.- Cachay Dfaz Horacio: Sindromo de Frugonl ocasionado por la enfermedad de Carrión. Rev, del Hosp. del Niño. Lima 1941.

75. - Wexss Pedno: Hacia una concepción de la Verruga peruana. An. de la Fac. de Med. Lima 1927.

76. -Delgado Cornejo l.: El brole de verruga en la vejiga. Rev. Méd. Per. No 73. Lima 1935.

77.-Campodónico Esteban: Caso interesante de Verruga o Verruga infecclosa. La Crónica Médica No 147. Lima 1895.

78. mbiffi U. y Carbajai G.: Sobre un caso de enfermedad de Carrión con verrucomas supurados. La Crónica Médica No 379. Lima 1904.

79. - Weiss Pedro: Verruga peruana. Dermatolagía y Sifillgratía. Pedro Castello. Ed. Cultural S. A. La Habana. Cuba 1945.

80. -Gonzalez Olachea M.: Un proceso pleural verrucoso en el curso de una verruga crónica. Rev. Méd. Per. N 58 y 59. Lima 1933.

81.-Quiroga y Mena R.: Verruga cerebral. La Crónica Médica. Lima 1889.

82.-Chres Lé́n: Revista Peruana de Pediatría. Lima 194.

83. - Lastres Juan B.: Los Neurobatonelosis. Sindromes neuropsíquicos de la enfermedad de Carrión. Verruga peruana. Ed. Médica Peruana S. A. Lima 1945.

84.-Aldana L. Antonio: Contribución al estudio de las complicaciones de la enfermedad de Carrión. Rev. de la Sanidad de policía Ne 50. Lima 1949.

85.-Strog R. Pinkerton H., Weinman D., Hertig M., Bennett B.: Nola preliminat del trabajo de la expedición de la Universidad de Harvard en el Perú en 1937. La Reforma Médica No 267. Lima 1937.

86. -Kuczynski Godard Max: Autoexperiencia del Prot. Kuczynsk1. La Reforma Médica N? 267. Lima 1937.

87.-Mackehenie D.: Esludio de un noduloma verrucoso. La Reforma Médica $\mathrm{N}^{9}$ 275. Lima 1838. 
88.-Mackehenie D. y Jménez Franco J.: Acerca del mosaico de poderes de la Bartonella baclliformis. La Reforma Médica Ne 217. Lima 1935.

89. -Aldana Lus: Estados biológicos de la Bartonella. Separata de la Rev. de la San. de policía. Lima 1948.

90. - Hercelles O.: La Anatomía patológica de la Verruga. Act. y trab. del V Congr. Méd. Latinoam. (VI Pamamer.). Tomo II. Lima 1914.

91.-Carvallo Constantino J.: La médula ósea en la enfermedad de Cambón. La Crónica Médica $N^{\circ} 531$ al 536. Lima 1911.

92.-Mackehenie D.: Mesénquima y enfermedad de Carrión. Imp. Víctor Larco Herrera. Măgd. Perú. 1930.

93.-Hercelles O.: La bartonella en los tejidos y en los órganos. Rev. Méd. Per. $\mathrm{N}^{\circ}$ 78. Lima 1935.

94.-Pinkerton y Weinman: Citodos por Weinman.

95.-Mackehenie D. y Alzamora C. V.: Las lesiones anatómicas del sislema nervioso en la enfermedad de Carrión. La Reforma Médica No 419. Lima 1939.

96. -Vélez Armando: De las verrugas. Gaceta Médica de Lima No 110. 1861.

97. - Hercelles O.: Ligeros apuntes sobre la histología patológica de la Verruga peruana. La Crónica Médica N²87 al 290. Lima 1900-1901.

98.-Escomel Enmundo: Anatomie Pathologique du verrucome de Carrion. An. Dermatologie et Syphil, Paris 1902.

99.-Garcta Godos M.: Contribución al estudio de la orina en la entermedad de Carrión. La Crónica Médica No 447 al 449. Lima 1907.

100.-Monge Carlos: Las icterias hemolíticas en patología tropical. La Reforma Médica $\mathrm{N}^{0}$ 2. Lima 1915.

101.-Guzmán Barrón Aleerto: La reacción de van den Bergh, homoaglulininas y hemolisinas en la enfermedad de Carrión. La Crónica Médica Ne 753. Lima 1926.

102. -Guzmán Barrón A.: El sindtome humoral sanguíneo en la enfermedad do Carrión. Y Colesterina. Rev. Médica Per. Ne 31 y 32. Lima 1931.

103.-Pons Julio y Urteaga O.: Vatiaciones de la aminoacidemía en enfermośs de verruga peruana $y$ en perros infectados con Barlonella Canis. A.ct. Ac. de Ciencias ex. fisc. y nat. Lima 1939.

104.-Merino César: Las seroproteínas en la enfermedad de Carrión. Tesis de la Fac. de Med. Lima 1939.

105.-Guzmán Barrón A.: La secreción gástrica y el factor intrínseco en la enfermedad de Carrión. Act. Méd. Per. No 12. Lima 1939.

106. -Delgado F. E. y Merino C.: Melabolismo pígmentarlo en la enfermedad de Carrión. Conf. Inst. Sanitas. Dic. 1946.

107. - Avendaño Leonidas: Daniel A. Carrión. La Crónica Médica N²2. Lima 1885.

108. -Schilling Vfctor: El cuadro hemático y su valor en la clínica. Ed. Labor. Madrid 1931.

109.-Klinge F.: Utber rheumatismus. Klinischen Wochenschrlft. Berlin 1920.

110. - Mackehenie D.: Verruga peruna y la tamillia tifo exantemático. An. Fac. de Med. Lima 1935. 
111.-Mackehenie D.: La enfermedad de Cartón o Verruga peruana y los tlíus exantemáticos. La Rel. Méd. $N^{0} 199$ y 203. Llma 1934-1935.

112.-Mackehenie D.: Verrue peruvienne et typhus exanthematique. Rev. Sud-Am. de Medecine et Chirurgie. Paris 1934.

113. - Alzamora C. V.: Contribuclón al estudio de la bartonelosis humana. Ann. de la Fac. de Med. Lima 1942

114.-Whipple H. G.: Protelns productions and exchange in the Body including Hemoglobin, plasina, proteins and cells proteins. Am. Journ. of the Med. Sc. 1938.

115. - Torrealba FÉlix: Valor diagnóstico del hemocultivo en la verruga peruana. Tesis Fac. de Med. Lima 1928.

116. - Jmánez Franco J.: Mortalidad e intercurrencla en la entermedad de Corrión. La Ref. Méd. N` 205. Llma 1938.

117.-Muñoz Bafata Carlos: Consideraciones generales sobre la transfuslón de sangre y su aplicación en la entermedad de Carrión. Tesla de la Fac de Med. Lima 1943.

118. -Riseyro Ramón E.: Verruga peruana y parallio $B$. La Crónica Médica $\mathrm{N}^{0}$ 834. Lima 1932.

119. -Arce Julián: El 606 en la llebre grave de Carrlón. La Crónica Médica $\mathbf{N}^{0}$ 560. Lima 1912.

120.-Bernales Sergio E.: La lerapia cilotlláctico en la Verruga peruana. Anales Hospitalarios. Lima 1929.

121. -Rocca y Bolo $\vec{N}$ Pedro: Tratamiento de la llebre grove de Carrín. La Refor. Mód. No 432. Lima 1944.

122. -ManRique Belisario: El problema terapéutico de la llebre anemizante grave de Carrión. La Rel. Méd. No 265 al 278. Lima 1937-1938.

123. -Nieto Domingo: Contribución al esludio de la Verruga en el depatamento de Ancash. Yungay 1938.

124.-Cachay Dfaz H y V́llchez L. I.: Vlemes Médlco del Instlluto Sanitas. Lima 194.

125.-Merino César: Reunión del Viernes Médico del inst. Sanitas. Lima 194.

126. - Aldana luis y Tisnado M. S.: Penicilina y entermedad de Carrión. Rev. de la San. do policía. Lima 1945.

127. - Batristini More G. Muñoz P. J. Y Tisnado M. S.: Acclón in vitro de la estreplomicina sobre la Bartonella. Arch. Per. de Pat. y Clín. Lima 1947.

128. - Aldana luis, Zubiate P. y Contreras F.: Un caso de verruga peruana resistente a la estreptomicina. Arch. Per. de Pat. y Clín. Lima 1947.

129.- - Hertig Marshall: Phlebolomus and Carrion's disease. Sup. to The Am. Journ. of Trop. Med. Baltimoro 1942. 